\title{
Pflanze-Herbivore-Parasitoid Interaktionen auf Wildrosenarten und ihren Hybriden entlang eines geographischen Gradienten
}

\author{
Dissertation \\ zur Erlangung des Doktorgrades \\ der Mathematisch-Naturwissenschaftlichen Fakultäten \\ der Georg-August-Universität zu Göttingen
}

vorgelegt von

Katrin Klinge, geb. Lehmann

aus Sulingen

Göttingen 2005 
D7

Referent: Prof. Dr. Teja Tscharntke

Korreferent: Prof. Dr. Matthias Schaefer

Tag der mündlichen Prüfung: 19. Januar. 2006 
Für meine Familie 


\section{Inhaltsverzeichnis}

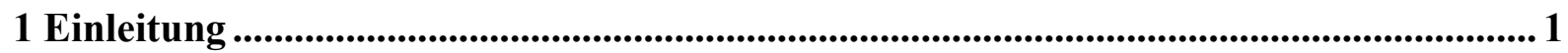

1.1 Effekte auf Pflanzen-Konsument-Parasitoid Interaktionen........................................... 1

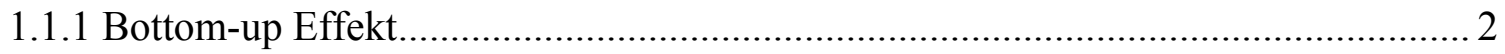

1.1.2 Interaktive und nicht-interaktive Pflanzen-Konsumenten Systeme ......................... 2

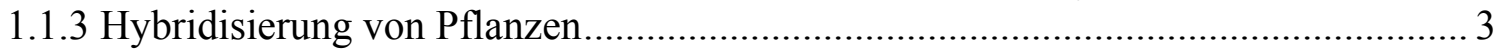

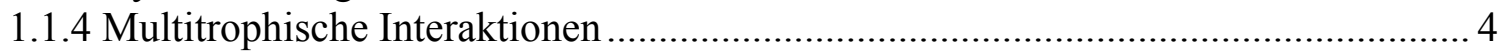

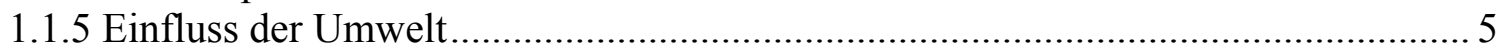

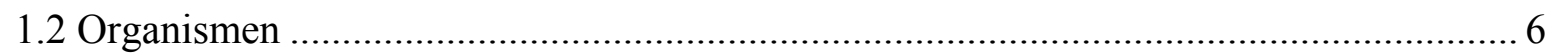

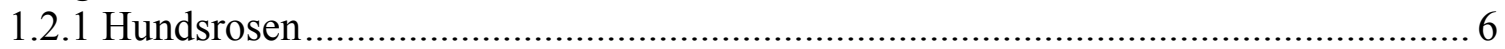

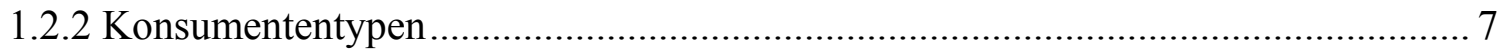

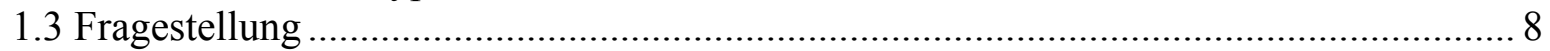

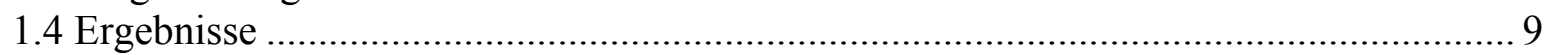

1.4.1 Unterschiede in der Häufigkeit von Rh. alternata, D. rosae und Phragmidium spp.9

1.4.2 Rosenhybride und deren Fressbarkeit ................................................................... 9

1.4.3 Herbivore-Parasitoid Interaktionen in D. rosae Gallen ....................................... 10

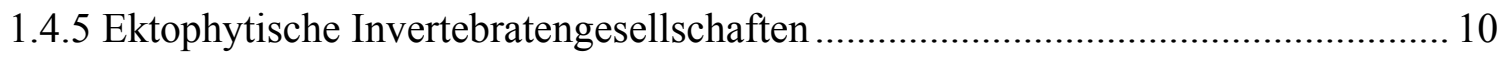

1.4.3 Genetische Differenzierung von Rh. alternata ................................................... 10

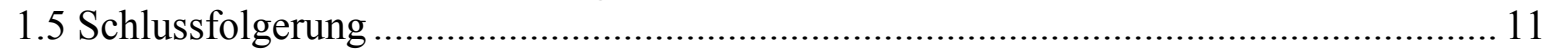

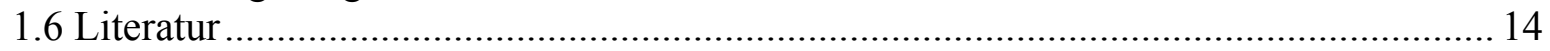

2 Variability in plant-consumer interactions across host species: Comparing fruit flies, gall wasps and rust fungi on wild roses ..................................................................... 22

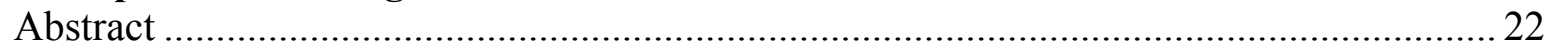

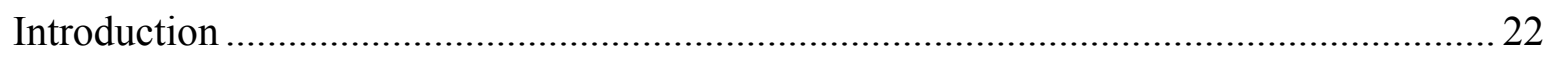

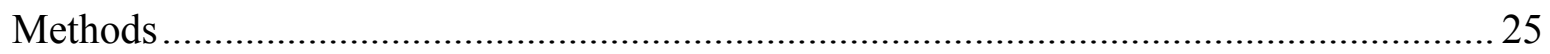

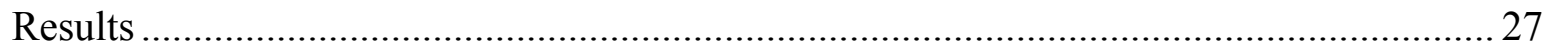

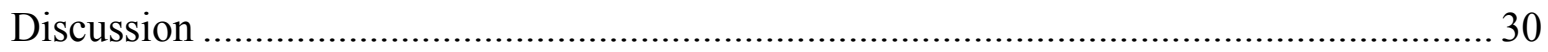

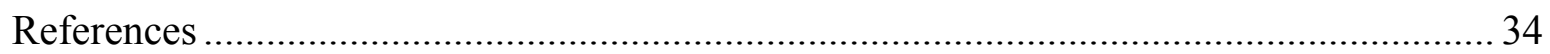

3 Does hybridisation of dog roses affect insect herbivory? ............................................40

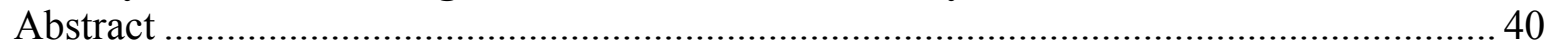

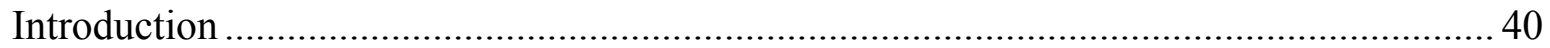

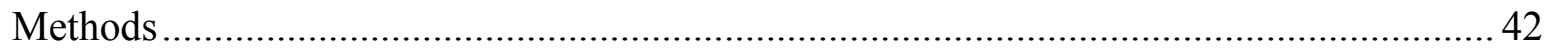

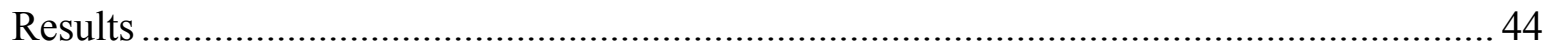

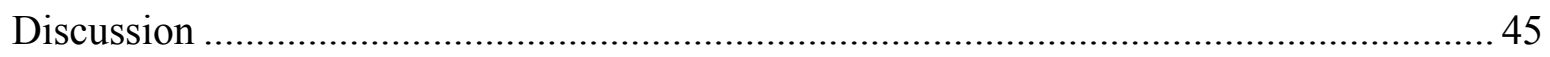

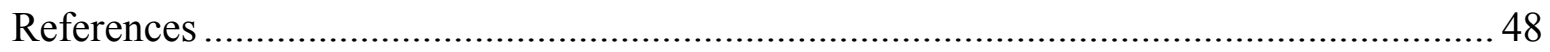

4 Cynipid gall-parasitoid interactions, comparing three dog rose species along a

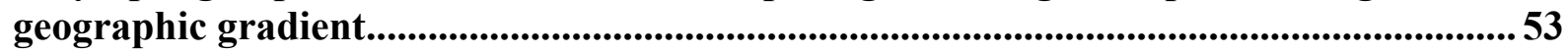

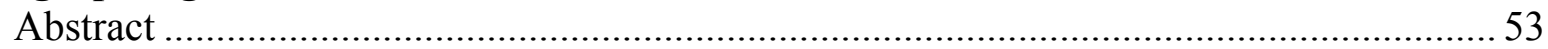

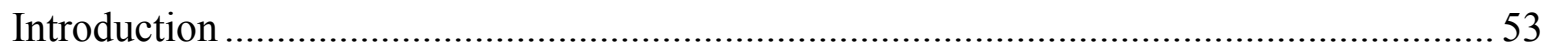

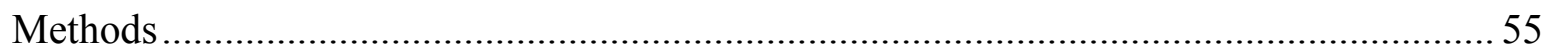

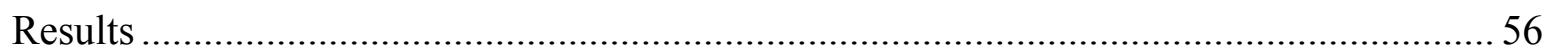

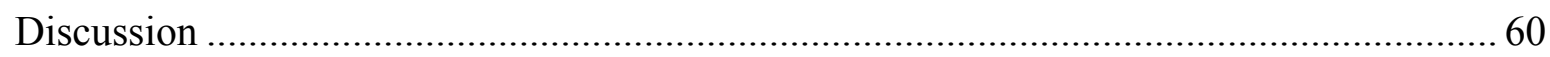

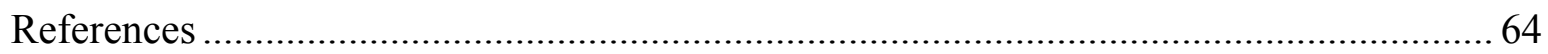

5 Invertebrate communities on three dog roses are not affected by leaf trichome traits of

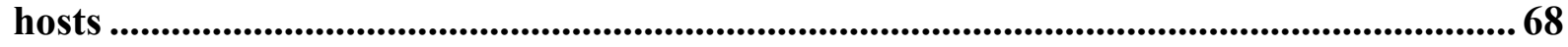




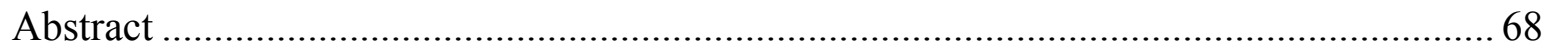

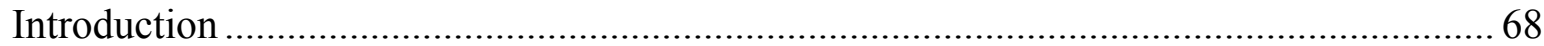

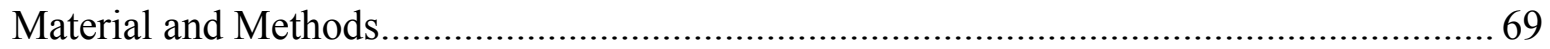

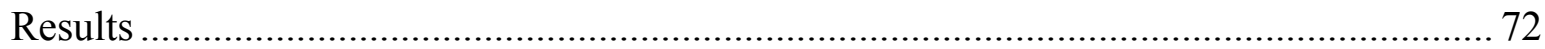

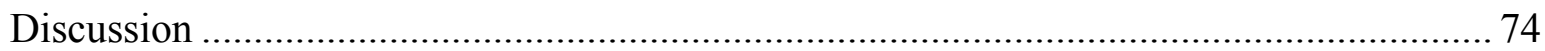

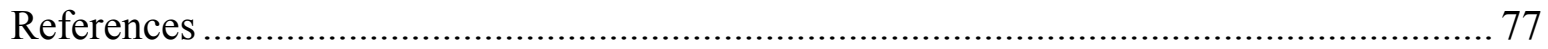

6 Genetic differentiation between populations of the European rose hip fly Rhagoletis

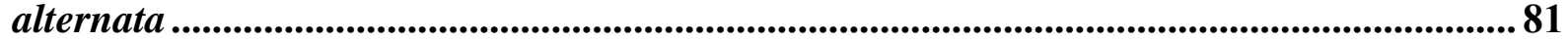

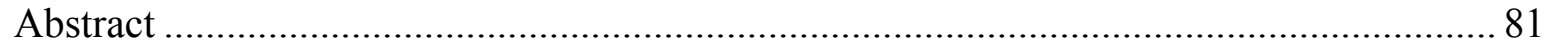

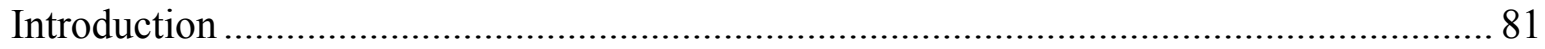

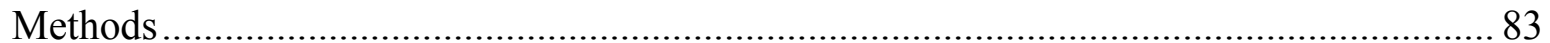

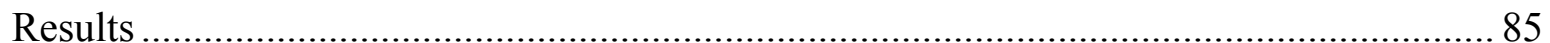

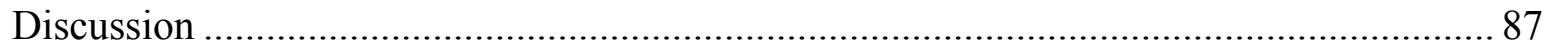

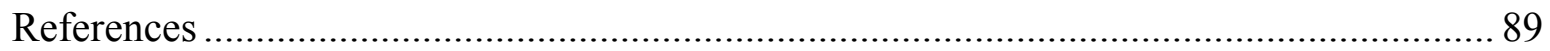

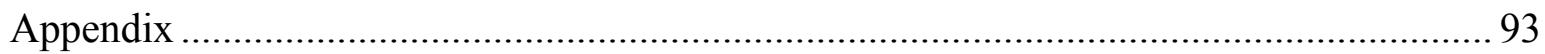

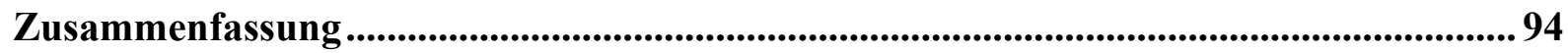

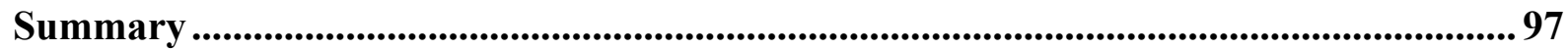

Erläuterung zu eigenen Beiträgen in der Arbeit .............................................................. 100

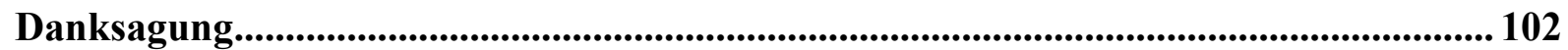

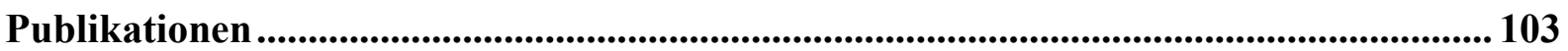

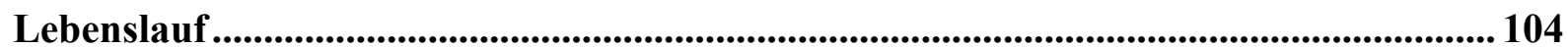




\section{Einleitung}

Herbivore Insekten und Pflanzen machen einen Großteil aller auf dieser Welt vorkommenden Arten aus (Strong et al. 1984, Herrera \& Pellmeyr 2002). Es wird angenommen, dass die Biodiversität von angiospermen Pflanzen und auf ihnen lebenden Insekten aus Interaktionen zwischen Herbivoren und ihren Wirtspflanzen resultiert (Ehrlich \& Raven 1964, Schluter 2000, Strong et al. 1984, Herrera \& Pellmeyr 2002). Phänotypische Unterschiede von Wirtspflanzenarten können Insekten zur Adaptation auffordern, so dass in Folge genetische Diversität entsteht und damit Artenvielfalt (Bush 1992, Leclair \& Brandl 1994, Scriber 2002, Blair et al. 2005, Sword et al. 2005).

In dieser Arbeit wurde untersucht inwieweit phänotypische Unterschiede zwischen nah verwandten Pflanzenarten sich auf die nächsten trophischen Ebenen übertragen und diese beeinflussen. Aufgrund der phänotypischen Vielfalt und des besonderen Artenreichtums der Wildrosen aus der Sektion Caninae wurde speziell diese Gruppe für die Untersuchungen ausgesucht. Differenzen in der Zusammensetzung von Gesellschaften, in der Häufigkeit von Konsumentenarten oder in der Konsumenten-Gegenspieler Zusammensetzung zwischen Wirtspflanzenarten wären ein Hinweis, dass die phänotypischen Unterschiede Artenvielfalt generieren können.

\subsection{Effekte auf Pflanzen-Konsument-Parasitoid Interaktionen}

Herbivoren können anhand der Art und Weise ihrer Nutzung der Wirtspflanze in unterschiedliche Gilden eingeteilt werden (Strong et al. 1984, Herrera und Pellmeyr 2002). Herbivoren mit kauenden Mundwerkzeugen fressen an Blättern, in Wurzeln, Früchten, Halmen oder Strünken. Eine weitere Gruppe daraus sind die Blattminierer, die das Gewebe zwischen der oberen und der unteren Blattepidermis fressen. Pflanzensaftsauger sind Herbivore mit extra angepassten Mundpartien, um Pflanzensäfte zu saugen. Gallbildende Insekten manipulieren ihre Wirtspflanze, damit diese ein Gewebe als Nahrungsressource und als Schutz für die Larven ausbildet. Insekten können ektophag an Pflanzen fressen, wie z.B. an Blättern, Knospen und Blüten, oder sie können endophag in Pflanzen fressen, wie es Minierer, Fruchtfresser oder Gallbildner tun.

Viele Arten aus diesen Gilden sind auf eine geringe Anzahl von Wirtspflanzenarten spezialisiert (Herrera \& Pellmeyr 2002). Einige Arten haben sich auf bestimmte Wirtspflanzen durch Koevolution angepasst (Wiebes 1979), andere nutzen eine gewisse Anpassung, um auf unterschiedlichen Pflanzen fressen zu können (Strong et al. 1984, Frenzel \& Brandl 2000). Die Insektenfauna einer Wirtspflanzenart besteht zumeist aus einer 
Mischung von Generalisten und Spezialisten (Strong et al. 1984, Tscharntke \& Greiler 1995, Schoonhoven et al. 1998, Brändle \& Brandl 2001). Diese Insektenfauna kann durch verschiedene Effekte beeinflusst sein, die im Folgenden dargestellt werden.

\subsubsection{Bottom-up Effekt}

Aus vielen Untersuchungen ist bekannt, dass phäno- und genotypische Unterschiede nah verwandter Pflanzenarten sich auf die Konsumenten auswirken. Sie zeigen, dass die Konsumentengesellschaft, die Populationsdichte und -dynamik oder auch die genetische Differenzierung von einzelnen Konsumentenarten „bottom-up“ beeinflusst wird (z.B. Da Costa \& Jones 1971, Fritz \& Price 1988, Mopper et al. 1990, Karban 1992, Hunter \& Price 1992, Fritz 1992, Underwood \& Rausher 2000, Hochwender \& Fritz 2004). Die Behaarung von Blättern und ebenso der Gehalt an sekundären Inhaltsstoffen können die Fressbarkeit von Blättern oder Pflanzenmaterial und die Überlebensrate von Raupen herabsetzen (Kubo et al. 1976, Chapman 1977, Eigenbrode et al. 1996, Haddad \& Hicks 2000, Frelichowski \& Juvik 2001). Unterschiede in der Größe und Phänologie von Früchten verschiedener Pflanzenarten können die auf diese Ressource angewiesenen Herbivoren zur Anpassung an diese Unterschiede auffordern und zur Ausbildung von Wirtsrassen führen, wie z.B. bei der Fruchtfliege Rhagoletis pomonella auf deren Wirtspflanzen Malus und Crataegus (Feder et al. 1997). Andere Parameter wie z.B. Struktur und Architektur oder Nährstoffgehalt der Pflanze beeinflussen die Qualität der Wirtspflanzen und begründen darüber Variationen in der Konsumentenebene (Rausher 1981, Southwood et al. 1982, Lawton 1983, Brodbeck \& Strong 1987). Untersuchungsergebnisse zeigen, dass Pflanzeneigenschaften nicht nur einzelne Organismen beeinflussen, sondern die Wachstumsrate von ganzen Insektenpopulationen über die Änderung der Überlebens- und Fortpflanzungsrate (z.B. Rausher 1981, Rossitter et al. 1988, Zangerl 1990, Underwood \& Rausher 2000). Die Insektenfauna einer Wirtspflanzenart kann somit eine direkte Folgerung aus der Pflanzenart sein.

\subsubsection{Interaktive und nicht-interaktive Pflanzen-Konsumenten Systeme}

Der Effekt der phäno- und genotypischen Variationen von Wirtspflanzen auf die nächste trophische Ebene wird durch eine Annahme von Caughley \& Lawton (1981) zu erklären versucht. Sie teilt Pflanzen-Konsumenten Systeme in zwei Typen ein: in nicht-interaktive und interaktive Systeme. In nicht-interaktiven Systemen hat der Konsument keinen Einfluss auf die Leistung und Fitness der Pflanze und beeinflusst nicht die Menge an verfügbaren 
Nahrungsressourcen für sich oder kommende Generationen. Konsumenten aus interaktiven Systemen beeinflussen die Wirtspflanze, indem sie die Fitness und die Leistung der Pflanze verringern.

Diese beiden Systeme bedingen unterschiedliche evolutionäre Abläufe (Strong et al. 1984). Konsumenten und Wirtspflanzen in einem interaktiven System umfassen symmetrische Interaktionen, mit der Folge eines dauernden Wettrüstens. Die Wirtspflanzen sammeln Eigenschaften gegen den Befall von Konsumenten und die Konsumenten passen sich auf diese Eigenschaften an (Ehrlich \& Raven 1964, Schluter 2000). In nicht-interaktiven Systemen gibt es keine symmetrischen Interaktionen zwischen Wirt und Konsument, da der Konsument und die Wirtspflanze unabhängig voneinander sind. Nur Konsumenten in interaktiven Systemen sollten, dem Ansatz der symmetrischen Interaktionen entsprechend, Unterschiede z.B. in ihrer Populationsdichte, -dynamik oder in ihrer genetischen Zusammensetzung auf verschiedenen Wirtspflanzenarten zeigen. Caughly \& Lawton (1981) gehen davon aus, dass die Arten, die nur in geringen Abundanzen vorkommen in einem nichtinteraktiven Verhältnis zu dem Wirt stehen. Arten mit hohen Abundanzen sollten ein interaktives System mit ihren Wirtspflanzen bilden. Bauer (1998) konnte nachweisen, dass auch Arten mit hohen Abundanzen in einem nicht interaktiven Verhältnis zu Wirtspflanzen stehen können. Nur bei Symmetrie des beidseitigen Einflusses ist Koevolution von Konsumenten-Pflanzen-Systemen möglich (Bauer 1998). Die Koevolution von Insektengesellschaften mit Pflanzen setzt nach Ehrlich \& Raven (1964) symmetrische Interaktionen zwischen Pflanzen und ihrem Konsumenten voraus.

\subsubsection{Hybridisierung von Pflanzen}

Die Hybridisierung von Pflanzen kann Pflanzeneigenschaften verändern und darüber die nächsten trophischen Ebenen beeinflussen (Karban 1992, Rieseberg 1995, Arnold 1997, Hochwender \& Fritz 2004). Die Nutzung der hybridisierten Wirtspflanze durch phytophage Insekten kann fünf verschiedene Muster hervorrufen (Fritz et al. 1999): Die Nutzung

- zeigt keine Unterschiede zwischen den Hybriden und Eltern,

- ist intermediär zwischen den Eltern,

- ist größer als auf den Eltern

- ist geringer als auf den Eltern oder

- ähnlich zu den Eltern.

Je nach Ausprägung des Musters ist eine unterschiedliche Rückkopplung des Herbivorenbefalls auf die Pflanzenpopulation möglich. Durch z.B. erhöhten Insektenbefall 
werden Hybridpopulationen gelöscht und Pflanzenarten stabilisiert (Arnold 1997, Arnold et al. 1999, Fritz et al. 1999). Phytophage Insekten können damit eine wichtige Komponente für die Populationsdynamik von Pflanzen sein (Stutzt und Thomas 1964, Rieseberg und Brunsfeld 1992, Rieseberg und Wendel 1993, Arnold 1997, Rieseberg und Carney 1998, Arnold et al. 1999, Jiang et al. 2000).

\subsubsection{Multitrophische Interaktionen}

In den achtziger Jahren richtete sich das Augenmerk von Ökologen von einfachen Interaktionen zwischen Pflanze-Herbivore und Herbivore-Gegenspieler auf multitrophische Interaktionen zwischen drei oder mehr Ebenen (Price 1986, Price \& Clancy 1986, Hare 1992, Fritz 1992, 1995, Hawkins 1994, Marquis \& Whelan 1996, Vinson 1999, Cattell \& Stiling 2004). Die Interaktionen zwischen Herbivoren und ihren Gegenspielern variieren oft zwischen den Wirtspflanzenarten der Herbivoren (Hare 1992, Fritz 1992, 1995, Fritz et al. 1997, Harvey et al. 2003, Cattell \& Stiling 2004).

Die Größe der Gallen von Eurosta solidaginis auf Solidago altissima ist durch den Pflanzengenotyp beeinflusst und dadurch auch die multitrophischen Interaktionen, da die Parasitierung in großen Gallen zumeist geringer ist (Weis \& Abrahamson 1985, Price and Clancy 1986). Die Qualität der Beute (Herbivore) ist oftmals auf verschiedenen Wirtspflanzenarten nicht einheitlich (Price et al. 1980, Price 1986, Fritz 1992, Hare 1992). Pflanzengifte können bei Herbivoren nach der Nahrungsaufnahme im Körper abgelagert sein und so einen Schutz gegen die Gegenspieler bieten (Tullberg \& Hunter 1996, Wink et al. 2000, Muller et al. 2001). Anteile von sekundären Inhaltsstoffen der Wirtspflanze können in der phytophagen Beute das Wachstum, die Entwicklung und das Überleben der Parasitoiden beeinflussen (Duffey et al. 1986, Gunasena 1990, Vinson 1999, Harvey et al. 2003).

Die Wahl der Wirtspflanzenart kann den Druck der Gegenspieler verändern (Price \& Clancy 1986, Gutierrez et al. 1994, Fritz 1995, Dickson \& Whitham 1996, Roininen et al. 1996, Stiling \& Rossi 1996). Wechselt der Konsument die Wirtspflanzenart kann dieses einen Zufluchtsraum eröffnen (Brown et al. 1995, Feder 1995). Herbivoren können die Wirtspflanzenart mit der größeren Überlebensrate vorziehen und so der Parasitierung ausweichen (Eisenbach 1996, Fritz et al. 1997, Cattell \& Stiling 2004). Es erscheint möglich mit der Untersuchung von multitrophischen Interaktionen auf verschiedenen Wirtspflanzenarten einen direkten Einfluss der Pflanze auf die Interaktionen zwischen Herbivoren und ihre Gegenspieler nachzuweisen, indem sich Unterschiede in der 
Zusammensetzung der Herbivore-Gegenspieler Gesellschaft zwischen den Wirtspflanzenarten zeigen.

\subsubsection{Einfluss der Umwelt}

Pflanzeneigenschaften, die Häufigkeit und genetische Zusammensetzung von Konsumentenarten und multitrophische Interaktionen können über geographische Distanzen variieren (Denno \& McClure 1983, Karban 1987, Hawkins \& Mills 1996, Tscharntke et al. 2001, Cattell \& Stiling 2004, Gaston et al. 2004, Johnson \& Agrawal 2005). Zum einen über lokale Umweltbedingungen die eine Veränderung der Qualität der Wirtspflanzen hervorrufen (Price \& Clancy 1986, Louda \& Collinge 1992, Stiling \& Rossi 1996, Moon \& Stiling 2000), zum anderen durch veränderte Abundanzen von Insekten- und Pflanzenarten über ihr Verbreitungsgebiet (Brown 1984, Brussard 1984, Hengeveld \& Haeck 1992, Sargarin \& Gaines 2002). Studien zu Interaktionen zwischen Wirtspflanzen, Herbivoren und Gegenspielern entlang geographischer Gradienten können helfen die relative Wichtigkeit der jeweiligen Prozesse, die die trophischen Ebenen strukturieren, einzuschätzen. Diese Untersuchungen versuchen auf großen räumlichen Skalen einheitliche Muster zu identifizieren (Gaston 2000). 


\subsection{Organismen}

Zur Untersuchung von Interaktionen zwischen Wirtspflanzen, Herbivoren und ihren Gegenspielern wurden Rosenarten aus der Sektion der Hundsrosen verwendet. Diese Sektion zeichnet sich durch hohe geno- und phänotypische Vielfalt aus (Wissemann \& Hellwig 1997, Wissemann 2003). Es wurden drei nah verwandte Hundsrosenarten ausgewählt, die sich in phänotypischen Eigenschaften unterscheiden.

Für die Untersuchung der Konsumentenfauna wurden die Gallwespe Diplolepis rosae und die Fruchtfliege Rhagoletis alternata als zwei auf Rosa lebenden phytophage Spezialisten ausgewählt und zwei Rostpilzarten aus der Gattung Phragmidium (Basidiomycetes), die zu den wichtigen Parasiten der Rosen gehören. Als ektophager Generalist wurde Spodoptera littoralis für die Untersuchung verwendet. Diese Konsumenten nutzen auf verschiedene Weise die Rosenpflanze als Nahrungsressource. Die Gallen von D. rosae beherbergen eine Herbivore-Gegenspieler Gesellschaft.

\subsubsection{Hundsrosen}

Europäische Hundsrosen (Rosa species, sect. Caninae (DC.) Ser.) haben ein ganz spezielles Meiose-System und bilden einen Komplex aus allopolyploiden Rosenarten (Wissemann 2000a, Wissemann 2005, Ritz et al. 2005b). In dem normalen Meiose-System hat die $\mathrm{F}_{1^{-}}$ Generation einen kompletten haploiden Chromosomensatz von beiden Eltern. Bei der „Canina-Meiose“ wird ein meist heterogamer Zustand durch die Befruchtung einer tetraploiden Eizelle mit einer haploiden Spermazelle aufrechterhalten (Blackburn and Harrison 1921, Täckholm 1920, 1922). Diese Heterogamie resultiert in einer betont mütterlichen Merkmalsvererbung, da 4/5 des Genoms mütterlich und nur 1/5 väterlich sind (Ritz \& Wissemann 2003, Wissemann \& Hellwig 1997). Durch diese matroklinalen Vererbung ähnelt der Nachwuchs in bestimmten Eigenschaften der Mutterpflanze (dem Samenpartner), wie z.B. in der Behaarung auf der Blattunterseite (Wissemann 2000b). Es wird vermutet, dass Hundsrosen allopolyploid entstanden sind (Gustafsson \& Håkansson 1942, Fagerlind 1948, Stebbins 1951) und basierend auf vielen Hybridisierungen der Artenreichtum der Hundsrosen seit der letzen Eiszeit sich entwickelte (Wissemann 2005, Ritz et al. 2005b).

Die Untersuchungen konzentrierten sich auf drei Arten der Hundsrosen. Diese drei Arten sind in Europa weit verbreitet und häufig (Timmermann \& Müller 1994). Trotz ihrer nahen Verwandtschaft unterscheiden diese Arten sich deutlich in ihren Phänotypen. Rosa canina L. hat kahle Blattunterseiten. R. corymbifera Borkh. ist eine auf den Blattunterseiten behaarte, 
filzige Rosenart. $R$. rubiginosa L. ist eine duftende Rose mit einer drüsigen Behaarung auf der Blattunterseite. Diese drei Rosenarten unterscheiden sich auch in der pflanzlichen Struktur und in ihrer Phenology (Timmermann \& Müller 1994).

\subsubsection{Konsumententypen}

Rhagoletis alternata

Die europäische Hagebuttenfruchtfliege Rhagoletis alternata FALL. (Diptera: Tephritidae) nutzt das Fruchtfleisch der Hagebutten von vielen Rosa Arten (White 1988). Die Weibchen legen Eier in die noch grünen Hagebutten und markieren die belegten Hagebutten durch ein Pheromon (Bauer 1986). Die Larven fressen ausschließlich im Fruchtfleisch und attackieren nicht die Samen der Frucht. Vollentwickelte Larven verlassen die Hagebutten um sich im Boden zu verpuppen, wo sie überwintern (Bush 1992). Das Fruchtfleisch dient zum Anlocken von vertebraten Konsumenten, was zu einer Verbreitung der Samen führt. Dadurch haben die Larven von Rh. alternata nur geringen bis gar keinen Einfluss auf die Fitness der Wirtspflanze und keinen Einfluss auf die Produktion der Früchte in den folgenden Generationen (Bauer 1986).

\section{Diplolepis rosae}

Gallen der Gallwespe Diplolepis rosae L. (Hymenoptera, Cynipoidea) wurden in Europa auf Rosa Arten von vielen Sektionen gefunden (Schröder 1967). Untersuchungen in Südschweden und in England fanden Gallen von D. rosae nur auf Rosenarten der Sektion Caninae (Harrison 1922, Stille 1984). Die meisten Beziehungen in der Gallengemeinschaft von D. rosae sind durch Blair (1945) beschrieben worden. Neben dem Gallinduzierer D. rosae können der Inquilin Periclistus brandtii R. (Hymenoptera, Cynipoidea) und neun häufige parasitierende Wespen in den Gallen gefunden werden (Blair 1945, Redfern \& Askew 1992). D. rosae wird durch Orthopelmamediator Thunb. (Hym. Ichneumonidae), Torymus bedeguaris L. (Hym. Torymidae), Pteromalus bedeguaris Thomson (Hym. Pteromalidae), Glyphomerus stigma Fabr. (Hym. Torymidae) und Eupelmus urozonus Dalman (Hym. Eupelmidae) parasitiert. G. stigma wird ebenso, wie Caenacis inflexa Ratzeburg (Hym. Pteromalidae) und Eurytoma rosae Nees (Hym. Eurytomidae) als Parasitoide von P. brandtii angesehen. P. brandtii frisst als Inquilin, ebenso wie die Larven von D. rosae Pflanzengewebe, von dem die Larven durch die Galle umgeben sind und 
induziert eigene Gallkammern. Ein negativer Effekt auf $D$. rosae des Inquilinen konnte bis jetzt nicht nachgewiesen werden (Stille 1984).

\section{Phragmidium spp.}

Gäumann (1959) beschreibt vier Rostpilzarten der Gattung Phragmidium auf Hundsrosen, von denen Phragmidium mucronatum (PERS.) SCHLTDL. und Ph. tuberculatum J.MüLler die häufigsten sind. Alle Vertreter der Phragmidiaceae haben einen Lebenszyklus ohne Wirtswechsel und sind ausschließlich auf den Rosaceae verbreitet. Die Koevolution zwischen Rostpilzen und ihren Wirten ist so eng, dass das Vorkommen von bestimmten Rostarten Rückschlüsse auf die phylogenetischen Beziehungen der Wirte erlaubt (Savile 1979). Die beiden Rostpilzarten zeigen keine morphologischen Unterschiede (Sydow \& Sydow 1915) und konnten während der Datenaufnahme nicht unterschieden werden. Sie sind im Folgenden unter Phragmidium spp. aufgeführt.

\section{Spodoptera littoralis}

Spodoptera littoralis Boisduval (Lepidoptera: Noctuidae) ist natürlich in Mitteleuropa nicht verbreitet. Sp. littoralis ist ein gut bekannter, polyphager Herbivore, dessen Raupen häufig als Modellorganismus in Laborexperimenten verwendet werden, um ein Maß zu z.B. Fraßeigenschaften von Pflanzenarten oder verschiedenen Pflanzengenotypen zu erhalten.

\subsection{Fragestellung}

Wirken sich die phänotypischen Unterschiede der nah verwandten Hundsrosenarten auf Konsumenten und ihre Gegenspieler aus, indem sich Unterschiede in der Dichte von einzelnen Arten, in ihrem Verhalten, in ihrer genetischen Differenzierung oder in Interaktionen von Herbivore-Gegenspieler Gesellschaften zeigen? Die allgemeine Fragestellung wurde in den folgenden Kapiteln in einzelnen Fragen untersucht:

Kapitel 2: Unterscheiden sich Rhagoletis alternata, Diplolepis rosae oder Phragmidium spp. in ihrer Häufigkeit zwischen den drei Rosenarten? Wie sicher können diese Dichteunterschiede durch phänotypische Unterschiede zwischen den Wirten, der Biologie der Konsumenten und dem Typen des Pflanzen-Konsumenten Systems erklärt werden?

Kapitel 3: Führt Herbivorie bei den drei Rosenarten und ihren Hybriden zu einem Selektionsdruck gegen Hybride und damit zu einer Stabilisierung der Rosenarten oder beeinflusst die Vererbung von Pflanzeneigenschaften die Fraßeigenschaft der Pflanzen? 
Kapitel 4: Wie verändern sich multitrophische Interaktionen in Diplolepis rosae Gallen mit dem Volumen der Gallen, der Wirtspflanze und dem Standort entlang eines geographischen Gradienten durch Deutschland?

Kapitel 5: Zeigen die Gemeinschaften von ektophytischen Invertebraten eine unterschiedliche Zusammensetzung auf den drei Rosenarten, die mit dem Unterschied der Behaarung auf der Blattunterseite in Zusammenhang gebracht werden kann?

Kapitel 6: Zeigt die Hagebuttenfruchtfliege Rhagoletis alternata eine genetische Differenzierung zwischen Populationen auf den drei Hundrosenarten auf einem geographischen Gradienten durch Deutschland und die Schweiz?

Die Untersuchungen in Kapitel 2, 4, 5 und 6 wurden an verschiedenen Standort entlang eines geographischen Gradienten vorgenommen, um einheitliche Muster, die auf den phänotypischen Unterschieden der Rosenarten basieren, zu identifizieren. Die Untersuchung in Kapitel 3 wurde im Alten Botanischen Garten in Göttingen an Rosenhybriden aus einem Kreuzungsversuch (Wissemann \& Hellwig 1997) unternommen.

\subsection{Ergebnisse}

\subsubsection{Unterschiede in der Häufigkeit von Rh. alternata, D. rosae und Phragmidium spp.}

Die Fruchtfliege Rhagoletis alternata, die Gallwespe Diplolepis rosae und der Rostpilz Phragmidium spp. zeigten signifikante Dichteunterschiede zwischen den Rosenarten und den Standorten. Der Erklärungswert der Varianz für den Faktor Rosenart nahm von Rh. alternata (1\%) über D. rosae (9\%) bis Phragmidium spp. (31\%) zu. Im Gegensatz dazu nahm der Erklärungswert der Varianz für den Faktor Standort in der gegenläufigen Richtung zu (64\% für Rh. alternata, $12 \%$ für D. rosae und 9\% für Phragmidium spp.), aber die relativen Varianzkomponten waren nicht unabhängig voneinander. Rh. alternata und D. rosae hatten die höhere Dichte auf der drüsig behaarten R. rubiginosa, während dessen Phragmidium spp. die höhere Dichte auf der kahlen R. canina zeigte. Nur Phragmidium spp. wirkte sich auf die Leistung der Pflanzen aus, indem die Hagebuttendichte auf $R$. rubiginosa und die Blattdichte auf R. canina mit Zunahme des Pilzbefalls abnahm (Kapitel 2).

\subsubsection{Rosenhybride und deren Fressbarkeit}

Fraßexperimente mit dem Generalisten Spodoptera littoralis auf den drei Rosenarten und ihren Hybriden zeigten keine Fraßunterschiede zwischen Hybriden und Nichthybriden. Deutliche Fraßunterschiede traten zwischen Rosenphänotypen mit und ohne drüsige Haare 
auf der Blattunterseite auf. Die Fraßmenge war deutlich geringer für Phänotypen mit drüsigen Haaren, welches $R$. rubiginosa und Hybriden mit $R$. rubiginosa als Mutterpflanze sind (Kapitel 3).

\subsubsection{Herbivore-Parasitoid Interaktionen in D. rosae Gallen}

Die Untersuchung der Herbivore-Parasitoid Gesellschaft in D. rosae Gallen zeigte, dass die Überlebensrate von D. rosae auf $R$. rubiginosa am höchsten, die der Parasitierung aber am niedrigsten war. Mit steigendem Gallvolumen verringerte sich auf den drei Rosenarten gleichermaßen die Parasitierung von D. rosae. Das Gallvolumen wurde nicht durch die Rosenarten beeinflusst. Der Faktor Standort hatte einen Einfluss auf die Überlebensrate von D. rosae und Prozent der Parasitierung, aber es gab keine Interaktionen zwischen den Faktoren Wirtspflanze und Standort. D. rosae und die Parasitierung korrelierten signifikant mit dem Längengrad, Breitengrad und der Höhe über N.N.. Die Überlebensrate von D. rosae nahm mit dem Längen- und Breitengrad zu und mit der Höhe ab. Dagegen nahm die Parasitierung mit dem Längen- und Breitengrad ab und mit der Höhe zu. Die einzelnen Parasitoidarten zeigten artspezifische Muster. G. stigma zeigte in größeren Gallen geringere Befallsraten und eine höhere Befallsrate in Gallen von R. rubiginosa. Diese Parasitoidenart folgte dem Muster der Gesamtparasitierung. Dagegen wurde O. mediator allein durch den Faktor Standort beeinflusst und T. bedeguaris durch Interaktionen zwischen dem Faktor Wirtspflanze und Standort (Kapitel 4).

\subsubsection{Ektophytische Invertebratengesellschaften}

Unterschiede in der Abundanz der rein phytophagen Gruppe der Aphidina und auch in anderen Invertebraten Taxa (Collembola, Araneae, Hymenoptera and Coleoptera) zwischen den drei Rosenarten waren gering. Ordinationen einer Redundanzanalyse zeigten außerdem eine ähnliche Komposition der Gemeinschaft der Invertebraten zwischen den drei Rosenarten (Kapitel 5).

\subsubsection{Genetische Differenzierung von Rh. alternata}

Die genetische Differenzierung von Rh.alternata Populationen zwischen den drei unterschiedlichen Rosenarten war signifikant. Doch ebenso, wie die Dichte von Rh. alternata nur geringe Unterschiede zwischen den drei Rosenarten zeigte (1\%, Kapitel 3), war auch die genetische Differenzierung von Rh. alternata Populationen zwischen den drei Rosenarten sehr 
gering (9\%). Auch entlang eines geographischen Gradienten durch Deutschland und der Schweiz wurde nur eine geringe genetische Differenzierung zwischen den Populationen gefunden (Kapitel 6).

\subsection{Schlussfolgerung}

Die Untersuchungen zeigen, dass der Effekt der phänotypischen Unterschiede der Hundsrosenarten je nach Konsumentenart oder betrachteter Insektengemeinschaft differiert. Wenn ein Effekt der phänotypischen Unterschiede die höheren trophischen Ebenen beeinflusste, zeigten die untersuchten Konsumentenarten teilweise eine positive Reaktionen auf $R$. rubiginosa, die Rosenart mit drüsigen Haaren auf den Blattunterseiten, teilweise auf $R$. canina und R. corymbifera. Diese beiden Rosenarten, ohne drüsige Haare auf den Blättern, erzeugten oft die gleiche Reaktion bei den untersuchten Konsumenten, so z.B. in der Dichte von Phragmidium spp. und den Gallen von D. rosae, der Koexistenz der HerbivorenGegenspieler Gemeinschaft in den Gallen von D. rosae und der Fraßmenge des Generalisten Sp. littoralis.

Konsumenten-Arten, die interaktiven und nicht-interaktiven Pflanzen-Konsumenten Typen zugeordnet wurden, waren unterschiedlich stark von den phänotypischen Unterschieden beeinflusst. Eine vermutlich geringe Wirtspezialisierung von Rh. alternata hatte keinen Einfluss auf die Fitness der Wirtspflanzen trotz hoher Befallsdichten. Die vermutlich hohe Wirtsspezialisierung von Phragmidium spp. beeinflusste, verbunden mit einer hohen Befallsdichte, die Hagebuttendichte und die Blattdichte im darauf folgenden Jahr negativ. D. rosae, die deutliche Dichteunterschiede zwischen den drei Rosenarten zeigte, beeinflusste nicht die Wirtspflanzen. Vermutlich durch die geringe Dichte, die D. rosae an den meisten Standorten und Büschen zeigte. Die Muster bei D. rosae sind intermediär zwischen einem interaktiven und nicht-interaktiven System. Die Ergebnisse unterstützen die Idee, dass interaktive Systeme, hier Phragmidium spp., von einem Wettrüsten zwischen Pflanze und Konsument gekennzeichnet sind. Ein ähnliches Wettrüsten ist bei nicht-interaktiven Systemen, hier Rh. alternata, bisher nicht beobachtet worden.

Die geringe Wirtsspezialisierung von Rh. alternata ist vermutlich für die beobachteten geringen genetischen Differenzen zwischen den drei Rosenarten verantwortlich. Ergänzende Erklärungen sind:

Der Genfluss zwischen Population von Rh. alternata muss hoch sein, da auch über große geographische Distanzen keine genetischen Differenzierungen auftreten. 
Das Muster der genetischen Differenzierung basiert auf einer aktuellen Ausbreitung des Verbreitungsgebietes.

- Der fortlaufende Genfluss zwischen den Rosenarten fungiert als hybridogene Brücke, die keine Ausprägung von Wirtsrasse zwischen den einzelnen Rosenarten ermöglicht.

Der Phänotyp der Rosenart beeinflusste nicht nur die Dichte der Gallen von D. rosae, sondern auch die der Insektengemeinschaft in den Gallen. R. rubiginosa, die Rosenart mit der höchsten Überlebensrate von D. rosae und der geringsten Parasitierung, scheint ein Zufluchtsort für D. rosae zu sein. Ein Grund für die inverse Dichteabhängigkeit der Parasitierung von D. rosae Gallen auf den drei Hundsrosenarten liegt vermutlich in den drüsigen Haare und den toxischen Inhaltsstoffen von R. rubiginosa. Ebenso beeinflusste das Gallvolumen die Insektengemeinschaft in den Gallen. Da sich das Gallvolumen nicht zwischen den Rosenarten unterschied, kann dieser Parameter nicht die Unterschiede der Gallgemeinschaft zwischen Rosenarten beeinflusst haben. Der Einfluss der Wirtspflanze änderte sich auch nicht mit der geographischen Position. Die einzelnen Parasitoidarten zeigten art-spezifische Muster, die damit die Koexistenz in den Gallen unterstützen. Die trophischen Interaktionen in den D. rosae Gallen wurden, auch über den geografischen Gradienten, prägnant durch die Wirtspflanze beeinflusst.

In dem Fraßexperiment mit Sp. littoralis zeigte sich eine geringere Fraßeigenschaft von R. rubiginosa, die Rosenart mit drüsigen Haaren, und Rosenhybride mit R. rubiginosa als Mutterpflanze. Es gab keine Fraßunterschiede zwischen Hybriden und Nicht-hybriden, aber zwischen Phänotypen mit und ohne drüsige Haare auf der Blattunterseite. Vermutlich bestimmt die matroklinale Vererbung von Eigenschaften, z.B. der drüsigen Haare, die Fressbarkeit der Phänotypen. Es kann somit ausgeschlossen werden, dass in der Sektion der Hundrosen Herbivorie als Stabilisierungsfaktor der einzelnen Rosenarten wirkt. Das Einführen von neuen genetischen Kombinationen in Rosenpopulationen, wird dadurch ermöglicht, dass Hybride nicht stärker befressen werden. Dies unterstützt die Ausbildung von Artenvielfalt bei den Hundsrosen durch Hybridisation.

Die Gemeinschaften von ektophytischen Invertebraten zeigten nur geringe Unterschiede in der Zusammensetzung auf den drei Rosenarten. Weder die rein zoophage Gruppe der Araneae, noch die Gruppen bestehend aus zoophagen und phytophagen Arten der Collembola und Hymenoptera, noch die rein phytophage Gruppe der Aphidina, zeigten deutliche Dichteunterschiede zwischen den drei Rosenarten. Eine Reaktion auf die phänotypischen Unterschiede der Rosenarten ist auf dieser taxonomischen Ebene nicht erkennbar. Die 
deutlichen Unterschiede in der Fressbarkeit zwischen den drei Phänotypen lassen sich nicht auf die invertebraten Gesellschaften übertragen. Vermutlich ist hier die taxonomische Einteilung zu grob, so dass sich eventuelle artspezifische Unterschiede in einzelnen Insektenoder Phytophagenarten nicht zeigen können.

Die Häufigkeit von D. rosae und Phragmidium spp. und die Fraßmenge des Generalisten Sp. littoralis ist vermutlich durch die drüsigen Haare und die toxischen Inhaltsstoffe von $R$. rubiginosa beeinflusst. Gallen von D. rosae hatten die höchste Dichte auf $R$. rubiginosa, Phragmidium spp. die höchste Dichte auf $R$. canina und $R$. corymbifera. Die Überlebensrate von $D$. rosae Individuen war auf $R$. rubiginosa am höchsten, während die Parasitierung dort am geringsten war. Die Fraßmenge der Phänotypen mit drüsigen Haaren war am geringsten. Der Phänotyp der Rosenart beeinflusst vermutlich dann die Konsumenten, wenn diese in engem Verhältnis zu den Wirtspflanzen stehen, wie z.B. die endophage Gallwespe D. rosae oder der endophytische Rostpilz Phragmidium spp., und Ressourcen nutzen, die deutliche Unterschiede zwischen den Rosenarten zeigen, wie z.B. Blätter mit und ohne drüsige Haare. Rh. alternata zeigte keine Beeinflussung durch die Rosenarten, da vermutlich die genutzte Ressource, die Hagebutte, keine morphologischen Unterschiede zwischen den untersuchten Rosenarten aufweisen.

Die genetische Differenzierung von Rh. alternata war nur gering zwischen den drei Rosenarten, was mit den geringen Dichteunterschieden zwischen den Rosenarten erklärt werden kann und einer geringen Wirtspezialisierung. Doch auch die beiden Rostpilzarten Phragmidium mucronatum und Ph. tuberculatum, die in der vorliegenden Arbeit großen Dichteunterschieden zwischen den Rosenarten zeigten, prägten keine Wirtsrassen aus (Ritz et al. 2005a). Die phänotypischen Unterschiede der Rosenarten scheinen sich nicht auf die genetische Differenzierung der auf ihnen lebenden Organismen auszuwirken. Hybridisierungsereignisse zwischen den Wirten können Brücken für die Konsumenten bilden, die es ermöglichen, sowohl die Elternarten als auch die Hybriden zu befallen (Floate \& Whitham 1993). Der hybridogene Ursprung der Caninae und die vermutlich andauernde Hybridisierung machen eine Artdifferenzierung schwierig. Die phänotypischen Unterschiede beeinflussen Konsumentenarten. Diese Beeinflussung scheint aber auf Dichtedifferenzen und die Fressbarkeit begrenzt und weitet sich nicht auf die Ebene der genetischen Konstitution der Konsumenten aus.

Multitrophische Interaktionen zwischen Pflanzen, Herbivoren und Gegenspielern können die Verteilung von Herbivoren auf verschiedenen Wirtspflanzenarten beeinflussen. Außerdem können unterschiedlichen Skalen, wie die Wirtspflanzenart, der Konsumententyp und die 
geographischen Lage, variierende Verteilungsmuster hervorrufen. Dies zeigt, dass es in Untersuchungen und Experimente zu Pflanzen-Herbivoren Interaktionen notwendig ist die tatsächliche Komplexität zu berücksichtigen, die sich aus multitrophischen Interaktionen, der geographischen Lage, dem Konsumententypen und der Wirtspflanzenart ergeben können.

\subsection{Literatur}

Arnold ML, (1997) Natural hybridization and evolution. Oxford University Press, New York

Arnold ML, Bulger MR, Burke JM, Hempel AL, Williams JH (1999) Natural hybridization: how low can you go and still be important? Ecology 80:371-381

Bauer G (1986) Life history strategy of Rhagoletis alternata (Diptera:Tephritidae), a fruit fly operating in a "non-interactive" system. J Anim Ecol 55:785-794

Bauer G (1998) Structure and function of a non-interactive insect-plant system. Oecologia 115:154-160

Blackburn K, Harrison JHW (1921) The status of the British rose forms as determined by their cytological behaviour. Ann Bot 35:159-188

Blair KG (1945) Notes on the economy of the rose-galls formed by Rhodites (Hymenoptera, Cynipidae). Proc R Entomol Soc London (A) 20:26-31

Blair CP, Abrahamson WG, Jackman JA, Tyrrel L (2005) Cryptic speciation and host-race formation in a purportedly generalist tumbling flower beetle. Evolution 59:304-316

Brändle M, Brandl R (2001) Species richness of insects and mites on trees: expanding Southwood. J Anim Ecol 70:491-504

Brodbeck B, Strong D (1987) Amino acid nutrition of herbivorous insects and stress to host plants. In: Barbosa P, Schutz JD (eds) Insect outbreaks. Academic Press, New York, pp. $347-364$

Brown JH (1984) On the relationship between abundance and distribution of species. Am Nat $124: 255-279$

Brown MB, Abrahamson WG, Packer RA, Way PA (1995) The role of natural-enemy escape in a gall-maker host plant shift. Oecologia 104:52-60

Brussard PF (1984) Geographic patterns and environmental gradients: the central-marginal model in Drosophila revisited. Annu Rev Ecol Syst 15:25-64

Bush GL (1992) Host race formation and sympatric speciation in Rhagoletis fruit flies (Diptera: Tephritidae). Psyche 99:335-357

Cattell MV, Stiling P (2004) Tritrophic interactions and trade-offs in herbivore fecundity on hybridising host plants. Ecol Entomol 29:255-263 
Caughly G, Lawton JH (1981) Plant-herbivore systems. In: May RM (ed) Theoretical Ecology. Blackwell Scientific Publications, Boston, pp. 132-66

Chapman RF (1977) The role of the leaf surface in food selection by Acridids and other insects. Colloques Internationaux CNRS. Comportement des insects et milieu trophique 265:133-148

Da Costa CP, Jones CM (1971) Cucumber beetle resistance and mite susceptibility controlled by bitter gene in Cucumis sativus L.. Science 172:1145-1146

Denno RF, McClure MS (1983) Variable plants and herbivores in natural and managed systems. Academic Press, New York

Dickson LL, Whitham TG (1996) Genetically based plant resistance traits affect arthropods, fungi, and birds. Oecologia 106:400-406

Duffey SS, Bloem KA, Campbell BC (1986) Consequences of sequestration of plant natural products in plant-insect-parasitoid interactions. In: Boethel DJ, Eikenbary RD (eds) Interactions of plant resistance and parasitoids and predators of insects. Horwood, Chichester, pp 31-60

Ehrlich PR, Raven H (1964) Butterflies and Plants: a study in coevolution. Evolution 18:586608

Eigenbrode SD, Trumble JT, White KK (1996) Trichome exudates and resistance to beet armyworm (Lepidoptera, Noctuidae) in Lycopersicon hirsutum f. typicum accessions. Popul Ecol 25:90-95

Eisenbach J (1996) Three-trophic-level interactions in cattail hybrid-zones. Oecologia $105: 258-265$

Fagerlind F (1945) Die Bastarde der Canina-Rosen, ihre Syndese- und Formbildungsverhältnisse. Acta Horgi Berg 14:7-37

Feder JL (1995) The effects of parasitoids on sympatric host races of the apple maggot fly, Rhagoletis pomonella (Diptera: Tephritidae). Ecology 76:801-813

Feder JL, Roethele JB, Wlazo B, Berlocher SH. (1997) Selective maintenance of allozyme differences between sympatric host races of the apple maggot fly. P Natl Acad Sci USA 94:11417-11421

Floate KD, Whitham TG (1993) The hybrid bridge hypothesis - host shifting via plant hybrid swarms. Am Nat 141:651-662

Frelichowski JE Jr., Juvik JA (2001) Sesquiterpene carboxylic acids from a wild tomato species affect larval feeding behaviour and survival of Helicoverpa zea and Spodoptera exigua (Lepidoptera: Noctuidae). J Econ Entomol 94:1249-1259 
Frenzel M, Brandl R (1998) Diversity and composition of phytophagous insect guild on Brassicaceae. Oecologia 113:391-399

Fritz RS (1992) Community structure and species interactions of phytophagous insects on resistance and susceptibility host plants. In: Fritz RS, Simms EL (eds) Plant resistance to herbivores and pathogens: ecology, evolution, and genetics. University of Chicago Press, Chicago, pp. 240-277

Fritz RS (1995) Direct and indirect effects of plant genetic variation in enemy impact. Ecol Entomol 20:18-26

Fritz RS, McDonough SE, Rhoads AG (1997) Effects of plant hybridization on herbivoreparasitoid interactions. Oecologia 110:360-367

Fritz RS, Moulia C, Newcombe G (1999) Resistance of hybrid plants and animals to herbivores, pathogens, and parasites. Annu Rev Ecol Syst 30:565-591

Fritz RS, Price PW (1988) Genetic variation in mortality of the leaf-folding sawfly on the arroyo willow. Ecol Entomol 15:25-35

Gaston KJ (2000) Global Patterns in Biodiversity. Nature 405:220-227

Gaston KJ, Genney DR, Thurlow M, Hartley SE (2004) The geographical range structure of the holly leaf-miner. IV. Effects of variation in host-plant quality. J Anim Ecol 73:911924

Gäumann E (1959) Rostpilze Mitteleuropas mit besonderer Berücksichtigung der Schweiz. Kommisionsverlag Buchdruckerei Büchler \& Co., Bern

Gunasena GH, Vinson SB, Williams HJ (1990) Effects of nicotine on growth, development and survival of the tobacco budworm (Lepidoptera: Noctuidae) and the parasitoid Campoletis sonorensis (Hymenoptera: Ichneumonidae). J Econ Entomol 83:1777-1782

Gustafsson A, Håkansson A (1942) Meiose in some Rosa-hybrids. Bot Not 95:331-334

Gutierrez AP, Mills NJ, Schreiber SJ, Ellis CK (1994) A physiologically based tritrophic perspective on bottom-up and top-down regulation of populations. Ecology 75:22272242

Haddad NM Hicks WM (2000). Host pubescence and the behaviour and performance of the butterfly Papilio troilus (Lepidoptera: Papilionidae). Environ Entomol 29:299-303

Harrison JWH (1922) The egglaying instincts of Rhodites rosae and certain deductions there from. The Vasculum 8:33-37

Hare JD (1992) Effects of plant variation on herbivores-natural enemy interactions. In: Fritz RS, Simms EL (eds) Plant resistance to herbivores and pathogens: Ecology, Evolution and Genetics. University of Chicago Press, Chicago, pp 278-298 
Harvey JA, Van Dam NM, Gols R (2003) Interactions over four trophic levels: foodplant quality affects development of a hyperparasitoid as mediated through an herbivore and its primary parasitoid. J Anim Ecol 72:520-531

Hawkins BA (1994) Pattern and process in host-parasitoid interactions. Cambridge University Press, Cambridge

Hawkins BA, Mills NJ (1996) Variability in parasitoid community structure. J Anim Ecol 65:501-516.

Hengeveld R, Haeck J (1982) The distribution of abundance. 1. Measurements. J Biogeogr 9:303-316

Herrera CM, Pellmeyr O (2002) Plant-animal interactions - An evolutionary approach. Blackwell Publishing, Oxford

Hochwender CG, Fritz RS (2004) Plant genetic differences influence herbivore community structure: evidence from a hybrid willow system. Oecologia 138:547-557

Hunter MD, Price PW (1992) Playing chutes and ladders: heterogeneity and the relative roles of bottom-up and top-down forces in natural communities. Ecology 73:724-732

Jiang CX, Chee PW, Draye X, Morrell PL, Smith CW, Paterson AH (2000) Multilocus interactions restrict gene introgression in interspecific population of polyploidy Gossypium (cotton). Evolution 54:798-814

Johnson MTJ, Agrawal AA (2005) Plant genotype and environment interact to shape a diverse arthropod community on Evening Primerose (Oenothera biennis). Ecology $86: 874-885$

Karban R (1987) Effects of clonal variation of the host plant, interspecific competition, and climate on the population size of folivorous thrips. Oecologia 74:298-303

Karban R (1992) Plant variation: its effect on populations of herbivorous insets. In: Fritz RS, Simms EL (eds) Plant resistance to herbivores and pathogens: ecology, evolution, and genetic. University of Chicago Press, Chicago, pp. 195-215

Kubo I, Lee YW, Pettei M, Pilkiewicz F, Nakanishi K (1976) Potent army worm antifeedants from the East African Warburgia plants. Chem Commun 24:1013-1014

Lawton JH (1983) Plant architecture and the diversity of phytophagous insects. A Rev Ent 28:23-29

Leclaire M, Brandl R (1994) Phenotypic plasticity and nutrition in a phytophagous insect: consequences of colonizing a new host. Oecologia 100:379-385

Louda SM, Collinge SK (1992) Plant resistance to insect herbivores: a field test of the environmental stress hypothesis. Ecology 73:153-169 
Marquis RJ, Whelan C (1999) Plant morphology, and recruitment of the third trophic level: subtle and little-recognized defenses. Oikos 75:330-334

Moon DC, Stiling P (2000) Relative importance of abiotically-induced direct and indirect effects on a salt marsh herbivore. Ecology 81:470-481

Mopper S, Whitham TG, Price PW (1990) Plant phenotype and interspecific competition between insects determine sawfly performance and density. Ecology 71:2135-2144

Muller C, Agerbirk N, Olsen CE, Boeve J-L, Schaffner U, Brakefield PM (2001) Sequestration of host plant glucosinolates in the defensive haemolymph of the sawfly Athalia rosae. J Chem Ecol 27:2505-2516

Price PW (1986) Ecological aspects of host plant resistance and biological control: interactions among three trophic levels. In: Boethel DJ, Eikenbary RD (eds) Interactions of plant resistance and parasitoid and predator of insects. Halsted Press, New York, pp. $11-30$

Price PW, Clancy KM (1986) Multiple effects of precipitation on Salix lasiolepis and populations of the stem-galling sawfly, Euura lasiolepis. Ecol Res 1:1-14

Price PW, Bouton CE, Gross P, McPheron BA, Thompson JN, Weis AE (1980) Interactions among three throphic levels: influence of plants on interactions between insect herbivores and natural enemies. Annu Rev Ecol Evol S11:41-65

Rausher MD (1981) Host plant selection by Battus philenor butterflies: the roles of predation, nutrition, and plant chemistry. Ecol Monogr 51:1-20

Redfern M, Askew RR (1992) Plant galls. The Richmond Publishing Co. Ltd., Slough

Rieseberg LH (1995) The role of hybridization in evolution: old wine in new skins. Am J Bot $82: 944-953$

Rieseberg LH, Brunsfeld SJ (1992) Molecular evidence and plant introgression. In: Soltis PS, Soltis DE, Doyle JD (eds) Molecular systematics of plants. Chapman and Hall, New York, pp 151-176

Rieseberg LH, Carney SE (1998) Plant hybridization. New Phytol 140:599-624

Rieseberg LH, Wendel JF (1993) Introgression and its consequences in plants. In: Harrison RG (ed) Hybrid zones and the evolutionary process. Oxford University Press, New York, pp 70-109

Ritz CM, Maier WFA, Oberwinkler F, Wissemann V (2005a). Different evolutionary histories of two Phragmidium species infecting the same dog rose hosts. Mycol Res 109:603-609

Ritz CM, Schmuths H, Wissemann V (2005b) Evolution by reticulation: European dogroses originated by multiple hybridization across the genus Rosa. J Hered 96:1-11 
Ritz CM, Wissemann V (2003) Male correlated non-matroclinal character inheritance in reciprocal hybrids of Rosa section Caninae (DC.) ser. (Rosaceae). Plant Syst Evol 241:213-221

Roininen H, Price PW, Tahvanainen J (1996) Bottom-up and top-down influences in the trophic system of a willow, a galling sawfly, parasitoids and inquilins. Oikos 77:44-50

Rossiter M, Schultz JC, Baldwin IT (1988) Relationships among defoliation, red oak phenolics, and gypsy moth growth and reproduction. Ecology 69:267-277

Sargarin RD, Gaines SD (2002) The 'abundant centre' distribution: to what extend is it a biogeographical rule? Ecol Lett 5:137-147

Savile DBO (1979) Fungi as aids in higher plant classification. Bot Rev 45:377-503

Schluter D (2000) The ecology of adaptive radiation. Oxford University Press, New York

Schoonhoven LM, Jermy T, von Loon JJA (1998) Insect-plant biology. From physiology to evolution. Chapmann \& Hall, London.

Schröder D (1967) Diplolepis (=Rhodites) rosae (L.) (Hym.: Cynipidae) and a review of its parasite complex in Europe. Tech Bull 9 Commonwealth Inst of Biol Control:93-131

Scriber JM (2002) Evolution of insect-plant relationships: chemical constraints, coadaptation, and concordance of insect/plant traits. Entomol Exp Appl 104:17-235

Southwood TRE, Moran VC, Kennedy CEJ (1982) The richness, abundance and biomass of the arthropod communities on trees. J Anim Ecol 51:635-649

Stebbins GL (1959) The role in hybridization in evolution. Proc Am Phil Soc 103: 231:251

Stille B (1984) The effect of host plant and parasitoids on the reproductive success of the parthenogenetic gall wasp Diplolepis rosae (Hymenoptera, Cynipidae). Oecologia 63:364-369

Stiling P, Rossi AM (1996) Complex effects of genotype and environment on insect herbivores and their enemies. Ecology 77:2212-2218

Strong DR, Lawton JH, Southwood R (1984) Insects on plants: Community patterns and mechanisms. Blackwell Scientific Publications, Oxford

Stutz HC, Thomas LK (1964) Hybridization and introgression in Cowania and Purshia. Evolution 18:183-195

Sword GA, Joern A, Senior LB (2005) Host plant-associated genetic differentiation in the snakeweed grasshopper, Hesperotettix viridis (Orthoptera: Acrididae). Mol Ecol $14: 2197-2205$

Sydow P, Sydow H (1915) Monographia Uredinearum Vol.3. Gebrüder Borntraeger, Leipzig 
Täckholm G (1920) On the cytology of the genus Rosa. A priliminary note. Svensk Bot Tidskr 14:300-311

Täckholm G (1922) Zytologische Studien über die Gattung Rosa. Acta Horti Berg 7:97-381

Timmermann G, Müller T (1994) Wildrosen und Weißdorne Mitteleuropas Landschaftsgerechte Sträucher und Bäume. Verlag des Schwäbischen Albvereins e.V., Stuttgart

Tscharntke T, Greiler HJ (1995) Insect communities, grasses, and grasslands. Annu Rev Entomol 40:535-558

Tscharntke T, Vidal S, Hawkins BA (2001) Parasitoids of grass-feeding chalcid wasps: a comparison of German and British communities. Oecologia 129: 445-451

Tullberg BS, Hunter AF (1996) Evolution of larval gregariousness in relation to repellent defences and warning coloration in tree-feeding Macrolepidoptera: a phylogenetic analysis based on independent contrast. Biol J Linn Soc 57:253-276

Underwood N, Rausher MD (2000) The effects of host-plant genotype on herbivore population dynamics. Ecology 81:1565-1576

Vinson SB (1999) Parasitoid manipulation as a plant defense strategy. Ann Entomol Soc Am 92:812-828

Weis AE, Abrahamson WG (1985) Potential selective pressures by parasitoids on a plantherbivore interaction. Ecology 66:1261-1269

White I (1988) Tephritid flies (Handbooks for the identification of British insects 10, part 5a). Royal Entomol. Soc., London

Wiebes JT (1979) Coevolution of figs and their insect pollinators. Annu Rev Ecol Evol S $10: 1-12$

Wink M, Grimm C, Koschmieder C, Sporer F, Bergeot O (2000) Sequestration of phorbolesters by the aposematically coloured bug Pachycoris klugii (Heteroptera: Scutelleridae) feeding on Jatropha curcas (Euphorbiaceae). Chemoecology 10:179-184

Wissemann V (2000a) Molekulargenetische und morphologisch-anatomische Untersuchungen zur Evolution und Genomzusammensetzung von Wildrosen der Sektion Caninae. Bot Jahrb Syst 122:357-429

Wissemann V (2000b) Epicuticular wax morphology and the taxonomy of Rosa (section Caninae, subsection Rubiginosae). Plant Syst Evol 221:107-112 
Wissemann V (2003) Hybridization and the evolution of the nrITS spacer region. In: Sharma AK, Sharma A (eds): Plant Genome, Biodiversity and Evolution Vol.1. Part A. Enfield, New Hampshire, Science Publishers, Inc. 57-71

Wissemann V (2005) Evolution by hybridisation. The influence of reticulate evolution on biosymmetrical patterns and processes in plants. Theory Bioscienc 123:223-233

Wissemann V, Hellwig FH (1997) Reproduction and hybridisation in the genus Rosa section Caninae (Ser.). Rehd Botanica Acta 110:251-256

Zangerl AR (1990) Furanocoumarin induction in wild parsnip: evidence for an induced defense against herbivores. Ecology 71:1926-1932 


\title{
2 Variability in plant-consumer interactions across host species: Comparing fruit flies, gall wasps and rust fungi on wild roses
}

\begin{abstract}
In this study we test the idea that differences in consumer density are related to traits of closely related host plant species, the consumer biology and the type of host-consumer interaction. We analyzed the variation in density of the tephritid fly Rhagoletis alternata FALL. (Diptera: Tephritidae), the cynipid wasp Diplolepis rosae L. (Hymenoptera, Cynipidae) and the rust fungus Phragmidium spp. (Basidiomycetes) on three sympatric dog rose species along a transect across Germany. The Eurasian dog roses (Rosa, section Caninae (DC) Ser.) form a taxon of closely related species. The three rose species, although closely related, differ in morphological traits (e.g., glabrous to glandular leaves). Densities of the three consumer species varied between host plant species and geographical location. However, the relative amount of variance of density accounted for by host plant species increased from Rh. alternata (1\%) to D. rosae (9\%) and Phragmidium spp. (31\%). Little hostplant specialisation in Rh. alternata was linked to little impact on host performance despite high densities, whereas the high specialisation of Phragmidium spp. was related to high host impact reducing hip density and leaf cover in the following year. D. rosae galls showed intermediate patterns. This is in line with the concept of interactive systems locked in a highly specialised plant-consumer arms race, thereby contrasting with non-interactive systems.
\end{abstract}

Keywords Density variation; host selection; interactive; non-interactive; pathogens; phytophagous insects

\section{Introduction}

The phenotypes of closely related host plant species often differ in traits that have been shown to affect the densities of consumer species (Da Costa and Jones, 1971; Karban, 1992; Underwood and Rausher, 2000). Caughley and Lawton (1981; see also Monro, 1967) divided plant-herbivore systems into two fundamental types: non-interactive and interactive systems. Non-interactive consumer species have no impact on the performance of their host plants and they do not affect the amount of food available to themselves and subsequent generations. In contrast, interactive consumers inflict serious damage upon their hosts and decrease the fitness of the host plant. Most of the rare species feeding on plants are non-interactive with little or no impact upon the dynamics of their host (Harris, 1973). Interactive and non- 
interactive plant-herbivore systems have different evolutionary trajectories (Strong et al., 1984; Bauer 1998). Interactive systems should be locked in a perpetual arms race during which traits that improve exploitation accumulate in the insect, whereas traits that deter herbivory accumulate in the host plant (Ehrlich and Raven, 1964; Schluter, 2000). Consequently, we expect a high degree of specialisation of the consumer species in interactive systems.

The population density of consumer species may also vary across geographic locations (Denno and McClure, 1983; Wainhouse and Howell, 1983; Service, 1984; Karban, 1987; Travis, 1996; Johnson and Agrawal, 2005). At least three aspects may mould densities of consumer species: 1. the phenotypic variation of the host plant species across space; 2 . the host plant-consumer interaction and 3. environmental variation. The study of consumer species on related host plants across environmental gradients can help to evaluate the relative importance of these processes.

In the present study we focussed on three endophytic consumer species, which appeared to represent interactive as well as non-interactive systems, on three closely related species of dog roses. European dog roses (Rosa species, sect. Caninae (DC.) Ser.), a hybrid complex of allopolyploids, are polymorphic in phenotypic characters. The complex genetic system of dog roses leads to a high phenotypic plasticity (Wissemann, 2000; Wissemann and Ritz, 2005). The three rose species, we focussed on, are widely distributed and abundant in central Europe and they often occur in the same habitats. Although closely related, the selected species of dog roses differ considerably in phenotype. Rosa canina L. is a glabrous rose, R. corymbifera Borkh., a hairy, tomentose rose and R. rubiginosa L. a rose with glandular trichomes on the lower leaf surface. These three species also differ in plant architecture and phenology (Timmermann and Müller, 1994). The phenotypic variation of the three rose species may have consequences for the abundance and population dynamics of consumers.

The European rose-hip fruit fly Rhagoletis alternata (Diptera, Tephritidae) infests the fleshy fruits of species from several Rosa sections (White, 1988). Adults emerge in early summer and females oviposit into green hips marking the attacked hips by an oviposition-deterring pheromone (Bauer, 1986). Larvae feed exclusively in the hypanthium and do not attack the seeds. The hypanthium of the hips attracts vertebrates, which disperse seeds. Mature larvae leave the hips for pupation and hibernate in the soil (Bush, 1992). The percentage of infested hips per shrub is usually high, frequently reaching 100\% (Bauer, 1998). Overall, Rh. alternata has little impact on the sexual reproduction of roses and thus on the fitness of the hosts (Bauer, 1998). Thereby the Rosa-Rh. alternata system can be considered non-interactive. 
The holarctic cynipid wasp Diplolepis rosae (Hymenoptera, Cynipoidea) is a univoltine gall maker (Adler, 1877). In Europe, the conspicuous and multichambered galls have been found on Rosa species from several sections (Schröder, 1967). In southern Sweden Stille (1984) found all species on which D. rosae occur belonging to the section Caninae, supporting Harrison (1922) with respect to England. Due to the physiological manipulation of the host plant, cynipid gall wasps are closely adapted to their host plants (e.g. Crawley and Long, 1995; Kato and Hijii, 1997). The relationship between plants and gall inducing insects are usually very specific, suggesting tight coevolutionary processes (Hilker et al., 2002). Galls develop as a result of interactions between the inducing insect and plant, wherein the insect gain control and redirect the growth and physiology of attacked organs to the insects' advantage (Shorthouse et al., 2005). D. rosae galls are rarely common enough to damage plants (Redfern and Askew, 1992). For example, Geyer (1988) found a mean of 2.2 galls per shrub. In contrast Schröder (1967) estimated D. rosae as a possible biological control for $R$. rubiginosa, which had developed into a serious problem in many parts of the South Island of New Island. He found galls of $D$. rosae to be numerous (sometimes 60 and more per shrub) in localities where the growth of the rose plants was poor. Thereby the plant-consumer relationship between $D$. rosae and Rosa appeared to be intermediate between interactive and non-interactive.

Rust fungi in the genus Phragmidium are important pathogens on Rosa. Two Phragmidium species, P. mucronatum and P. tuberculatum, infect the three dog rose species (Ritz et al., 2005). The growth of Phragmidium in Rosa seems to be systemic (Williams, 1938; Hoffmann et al., 1985). Savile (1979) noted that the strong host-specifity of rust fungi is based on coevolution. Rust infections of the genus Phragmidium often reach a high level on the host plants and are thought to act as biocontrol agents of the invasive European blackberry (Rubus fructicosus agg.) in Australia, due to their negative impact on the fitness of the host plant (Bruzzese and Hasan, 1986; Pigott et al., 2003; Evans et al., 2005). The plant-consumer relationship between Phragmidium spp. and Rosa system could be classified as interactive.

We investigated the density of the three consumer species on the three rose species across a geographic gradient throughout Germany. We tested the hypothesis, that the phenotypic differences between the three rose species affect the consumer species, only when there is an interactive relationship to the host plants. For interactive systems we expected (following Caughley and Lawton, 1981) that the consumer density vary considerably between different host species, whereas in non-interactive systems the density varies mainly in response to environmental factors. For interactive, but not for non-interactive systems, we expect a 
coupling of the evolutionary trajectories of host and consumer species. In particular we posed two questions. First, the three consumers are known to attack all the three rose species. However, do the consumer species show differences in density between host species? Secondly, if so, to what extent can these differences be explained by the phenotypic variation between hosts, the biology of the consumers and the type of host-consumer interaction?

\section{Methods}

We monitored the density of larvae of Rh.alternata, D. rosae galls and sporangia of Phragmidium spp. on the three host plants at 18 sites along a transect from Southern to Northern Germany (Fig. 1). In all selected locations the three host plant species occurred within the same habitat. For each rose species we sampled 3 to 5 randomly selected shrubs within each sample site. Shrubs were marked individually. Longitude, latitude and altitude of each sample site were recorded using Global Positioning System ("GPS 12 Personal Navigator", (C) Garmin International Inc.). We performed a principal component analysis on the correlation matrix of latitude, longitude and altitude of each site in order to rank the 18 sites. The scores of the first component (explained variance 76\%) ranked sites from south to north, from west to east and from high to low altitudes. This rank was used for Fig. 1 and 2.

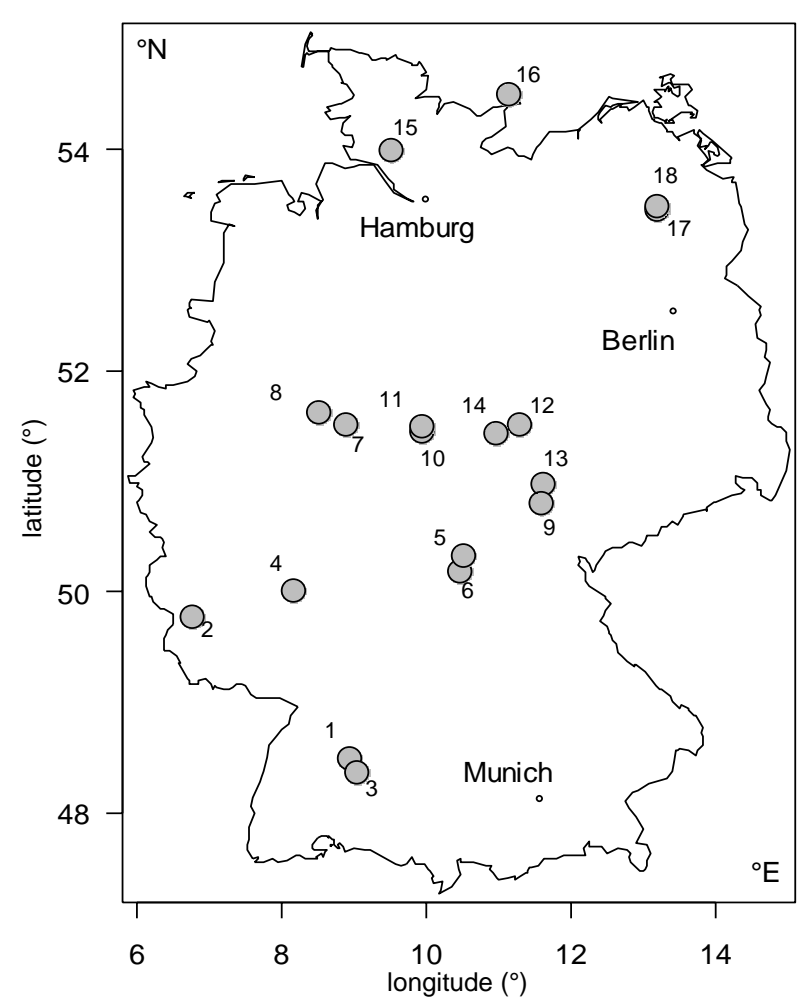

Fig.1. Geographical location of sample sites across Germany and rank of sample sites used in Fig. 2. For orientation we also plot location of cities with more than 500.000 inhabitants (= small black circles). 
To monitor the density of Rh. alternata we haphazardly collected 50 hips from each shrub in September 2002 and 2003. We used the percentage of hips with larvae of Rh. alternata as an estimate of density. During the same sampling dates, rose shrubs were searched for galls of D. rosae. The total number of galls on each shrub was used as a measure of gall density. In the second year we were only able to sample 17 sites, because the rose shrubs of site 11 were removed. Therefore we used only 17 sites for the analyses of Rh. alternata and D. rosae. For the sampling of Rh. alternata and D. rosae we used in both years the same shrubs. The density of Phragmidium spp. was estimated in June 2002 only. Sampling in 2003 was done in September, hence in 2003 the counts of Phragmidium spp. are not comparable with the counts in 2002 and we concentrate on the data from 2002. The two Phragmidium species show strong morphological resemblance (Sydow and Sydow 1915) and could not be separated in the field. We counted the number of visible sporangia along $30 \mathrm{~cm}$ from the tip of a branch. This count was divided by the number of leaflets along the branch. Five randomly selected branches were searched for each shrub and we use the mean for further analyses.

Since plant architecture may influence abundance of invertebrates (Strong et al., 1984), we collected in 2002 data to characterise the architecture of the sampled shrubs. We measured shrub height $[\mathrm{m}]$ and diameter [m], leaf cover [10\% classes], density of hips and leaflets of the compound leaves, number of shoots and diameter of the largest shoot [cm]. Hip and leaflet density of a shrub was sampled by counting hips and leaflets along randomly selected branches. We counted hips and leaflets along $30 \mathrm{~cm}$ from the tip of five randomly selected branches. Again we used the mean for subsequent analyses. The leaf cover of a shrub was estimated as the percentage of a $400 \mathrm{~cm}^{2}$ frame covered by leaves (mean of three randomly located frames on each shrub). Except for the leaf cover all variables were log-transformed. To reduce the number of variables we performed a PCA on the correlation matrix. Two principle components passed the Kaiser criterion. PC1 characterizes the size of a shrub (35\% explained variance; variables with loading $>0.6$ : height, diameter, diameter of the largest shoot) and PC2 the foliar density of a shrub (26\% explained variance; loadings $>0.6$ : density of leaflets and hips, leaf cover).

Damage of plants by insects resulting from direct consumptive loss and from the loss of reproductive, photosynthetic or absorptive tissues reduces the productivity of the plant (Harris 1974). To characterize some basic aspects of the fitness of each rose shrub we used the measured density of hips (reproductive output) as well as the leaf cover (a surrogate of photosynthetic capacity). Only these two parameters were estimated in 2002 and 2003 . The hip density in 2003 was positively correlated with the hip density in 2002 for R. rubiginosa 
$\left(\mathrm{n}=69, \mathrm{r}^{2}=0.15, P<0.01\right)$, R. corymbifera $\left(\mathrm{n}=64, \mathrm{r}^{2}=0.25, P<0.001\right)$ and $R$. canina $(\mathrm{n}=67$, $\left.\mathrm{r}^{2}=0.15, P<0.01\right)$. The leaf cover in 2003 was positively correlated with the leaf cover in 2002 for $R$. rubiginosa $\left(n=72, r^{2}=0.12, P<0.01\right)$ and $R$. corymbifera $\left(n=68, r^{2}=0.28, P<0.001\right)$, but not for $R$. canina $\left(\mathrm{n}=71, \mathrm{r}^{2}=0.014, P=\right.$ n.s. $)$.

Prior to all statistical analyses, density data of Rh. alternata were arcsine-transformed, counts of D. rosae galls square-root transformed, and densities of Phragmidium spp. sporangia logtransformed to reduce heterogeneity of variances and normalize distributions. We tested the density of Rh. alternata, D. rosae and Phragmidium spp. against two factors, rose species and sample site (general linear model with two factors; sample site random) using the scores of the two principal components extracted from the plant variables as covariables. For $R h$. alternata and D. rosae the data from 2002 and 2003 were used as repeated measures with type I sum of squares. Due to the fact that the study sites were considered as a random factor the Fratios were calculated using a restricted mixed model (see Minchinton and Ross, 1999; Quinn and Keough, 2002). To estimate the percentage of variance accounted by each factor and the interaction between the two factors we estimated variance components using restricted maximum likelihood (REML; Searle et al., 1993). For Rh. alternata and D. rosae we used the mean across the two years. Note that the factor "species" was fixed in our analysis;

nevertheless we present variance components to facilitate comparison of the relative importance of the two factors (see also Brown and Mosteller, 1991). All correlations in this study are based on Pearson moments (linear correlations). For all statistical calculations we used STATISTICA 6.1 .

\section{Results}

On some shrubs all sampled hips were attacked by Rh. alternata. The back transformed value of the mean density across all shrubs was 24\% in 2002 and 54\% in 2003 (see also Fig. 2 and Fig. 3). Rh. alternata showed the highest densities on R. rubiginosa, in 10 (2002) and 6 (2003) out of the 17 sampled sites (Fig. 2 A-B). For all three host plants we found a significant correlation between densities in 2002 and 2003 (Fig. 3 A-C). We found a significant difference in density between rose species and significant differences between sites and years (Table 1). The variation in density was not a simple cline across South to North. The estimated percentage of variance due to differences between rose species was only $1 \%$, whereas the differences between sites accounted for $64 \%$ of the variance (interaction rose species $\mathrm{x}$ site: $8 \%$ ). Although the percentage of variance due to the interaction was low, the interaction was significant (Table 1). The geographic pattern of density was rather consistent 
across years (see also Fig. 3 A-C: correlation across years). The density of hips and the leaf cover in 2003 was independent of the percentage of hips infested by Rh. alternata during 2002 (hip density for all three rose species: $r^{2}<0.02, P=n$.s.; leaf cover for all three rose species: $\mathrm{r}^{2}<0.02, P=$ n.s.).

Table 1 Effect of rose species (Rosa canina, R. corymbifera and R. rubiginosa) and geographical location of sample sites on the densities of Rhagoletis alternata, Diplolepis rosae and Phragmidium spp. after accounting for differences in shrub characteristics with the two principal components (PC1 and PC2). For Rh. alternata and $D$. rosae we present repeated measures analyses. $\mathrm{SS}=$ sum of square, $\mathrm{df}=$ degrees of freedom; the F-ratio was calculated with the appropriate error term; *P<0.05, ** $P<0.01$, *** $P<0.001$.

\begin{tabular}{llllllllll}
\hline & \multicolumn{3}{c}{ Rh. alternata } & \multicolumn{3}{c}{ D. rosae } & \multicolumn{5}{c}{ Phragmidium spp. } \\
& SS & df & F & SS & df & F & SS & df & F \\
\hline PC1 & 0.16 & 1 & 2.24 & 0.59 & 1 & 1.24 & 2.80 & 1 & $29.11^{* * *}$ \\
PC2 & 0.20 & 1 & 2.71 & 16.93 & 1 & $35.61^{* * *}$ & 0.90 & 1 & $9.33^{* *}$ \\
Site (S) & 38.73 & 16 & $33.63^{* * *}$ & 34.33 & 16 & $4.51^{* * *}$ & 9.54 & 17 & $5.84^{* * *}$ \\
Host (H) & 1.15 & 2 & $3.69^{*}$ & 12.86 & 2 & $6.01^{* *}$ & 5.99 & 2 & $14.37^{* * *}$ \\
S x H & 4.98 & 32 & $2.16^{* * *}$ & 34.21 & 32 & $2.25^{* * *}$ & 7.08 & 34 & $2.17^{* * *}$ \\
Residuals & 11.45 & 159 & & 82.26 & 173 & & 19.98 & 208 & \\
Year (Y) & 10.77 & 1 & $48.09^{* * *}$ & 10.11 & 1 & $18.14^{* * *}$ & & & \\
Y x PC1 & 0.18 & 1 & $5.99^{*}$ & 0.02 & 1 & 0.06 & & & \\
Y x PC2 & 0.18 & 1 & $6.21^{*}$ & 4.61 & 1 & $17.45^{* *}$ & & & \\
Y x S & 3.58 & 16 & $7.61^{* * *}$ & 8.92 & 16 & $2.11^{* *}$ & & & \\
Y x H & 0.29 & 2 & 2.01 & 2.54 & 2 & 1.89 & & & \\
Y x S x H & 2.28 & 32 & $2.42^{* * *}$ & 21.53 & 32 & $2.55^{* * *}$ & & & \\
Residuals & 4.68 & 159 & & & & & & & \\
\hline
\end{tabular}

Gall density of $D$. rosae was much skewed. On few shrubs found up to 32 D. rosae galls. On most shrubs (72\%), however, we found no galls at all. Mean density across all shrubs was 0.051 in 2002 and 0.25 in 2003 (back transformed values; see also Fig. 2 C-D and Fig. 3 DF). D. rosae showed the highest densities on R. rubiginosa, in 9 (2002) and 10 (2003) out of the 17 sampled sites (Fig. 2 C-D). The gall wasp D. rosae showed significant differences in density across rose species and sites with a significant interaction (Table 1); $9 \%$ of the variance in the gall number of D. rosae was due to rose species and $12 \%$ due to the sites (interaction 21\%). Again we found no simple geographic cline. For all three host plants we found a significant positive correlation between densities (mean for each shrub) of 2002 and 2003 (Fig. 3 D-F). We found no negative correlations between the number of galls on a shrub in 2002 and the number of hips or leaf cover during 2003 (hip density for all three rose species: $\mathrm{r}^{2}<0.02, P=$ n.s.; leaf cover for all three rose species: $\mathrm{r}^{2}<0.02, P=$ n.s.). 
2002
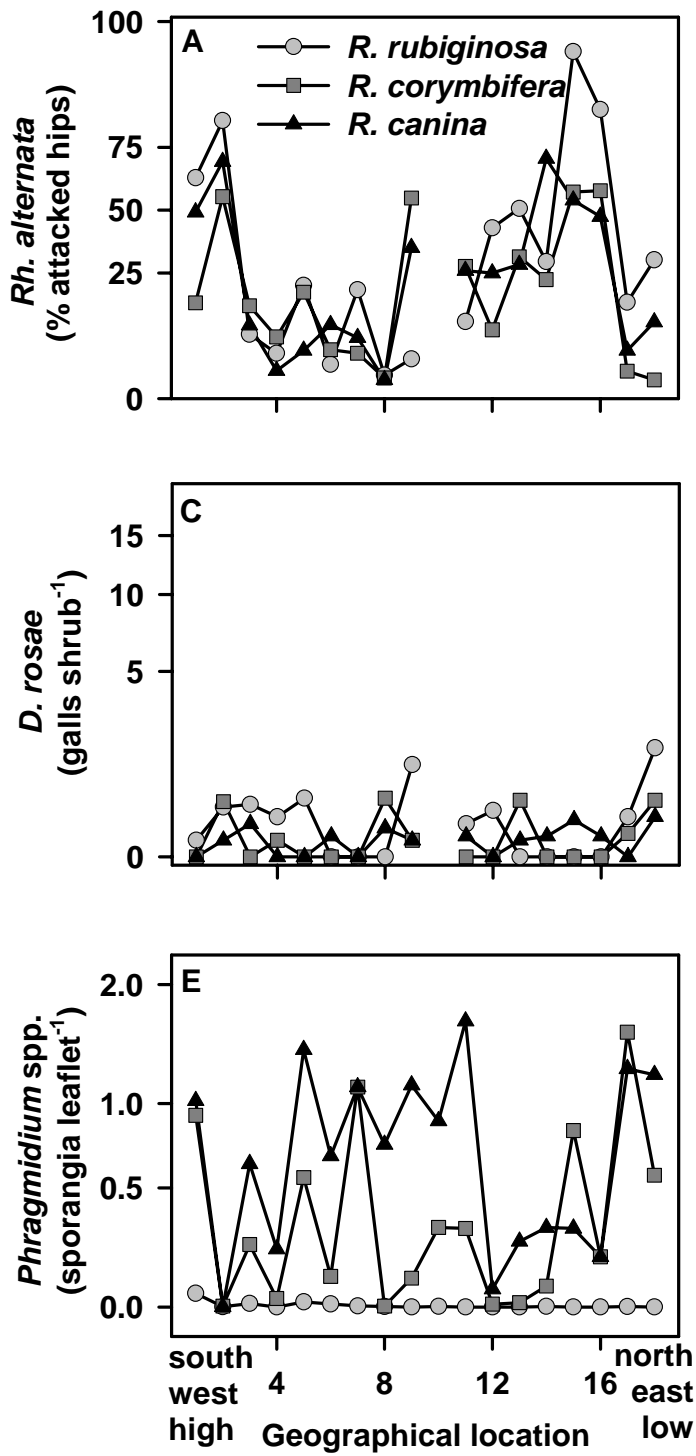

2003
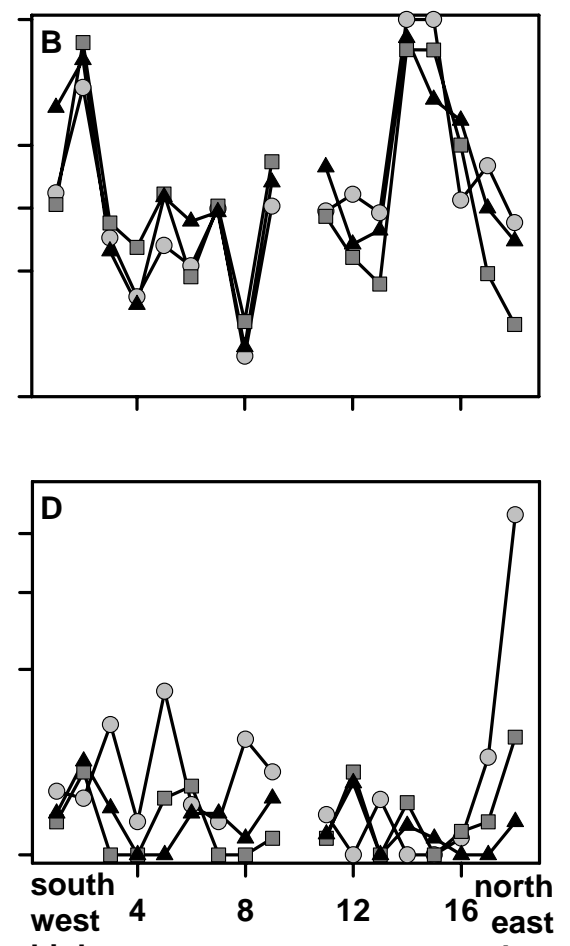

high Geographical location low

Fig. 2. Patterns of density across the three dog rose species (grey circle $=$ Rosa rubiginosa, dark-grey square $=$ $R$. corymbifera, black triangle $=R$. canina) and the geographical locations in the two study years 2002 and 2003 for (a, b) Rhagoletis alternata, (c, d) Diplolepis rosae and (e) Phragmidium spp. (corrected means were calculated with General Linear Model analyses). Geographical location = ranking of the 18 sites from south to north, from west to east and from high to low altitudes based on results from a principal component analysis (s. Fig. 1).

On average the number of Phragmidium spp. sporangia per leaflet may reach 4.5 for an individual shrub. The back transformed value of mean density was 1.27 (2002; no data for 2003; see also Fig. 2 E and Fig. 4). Phragmidium spp. had the highest densities on R. canina in 13 out of 18 sites (Fig. 2 E). The density was significantly different between sites and rose species (Table 1); $31 \%$ of the variance in the number of sporangia was due to the rose species and $9 \%$ due to sites (interaction 12\%). The leaf cover of R. canina in 2003 decreased with increasing density of sporangia in the preceding year (marginally significant; Fig. 4 A). To examine, whether this was an effect of the attack by Phragmidium spp., we also correlated the leaf cover in 2002 with attack by Phragmidium spp. in 2002. However, this correlation was 
for all three rose species not significant $\left(\mathrm{r}^{2}<0.004, P=\right.$ n.s. $)$. The hip density of $R$. rubiginosa in 2003 decreased with increasing density of sporangia in the preceding year (Fig. 4 B). Again, the hip density in 2002 was independent of Phragmidium spp. density in the same year for all three rose species $\left(\mathrm{r}^{2}<0.04, P=\right.$ n.s. $)$.

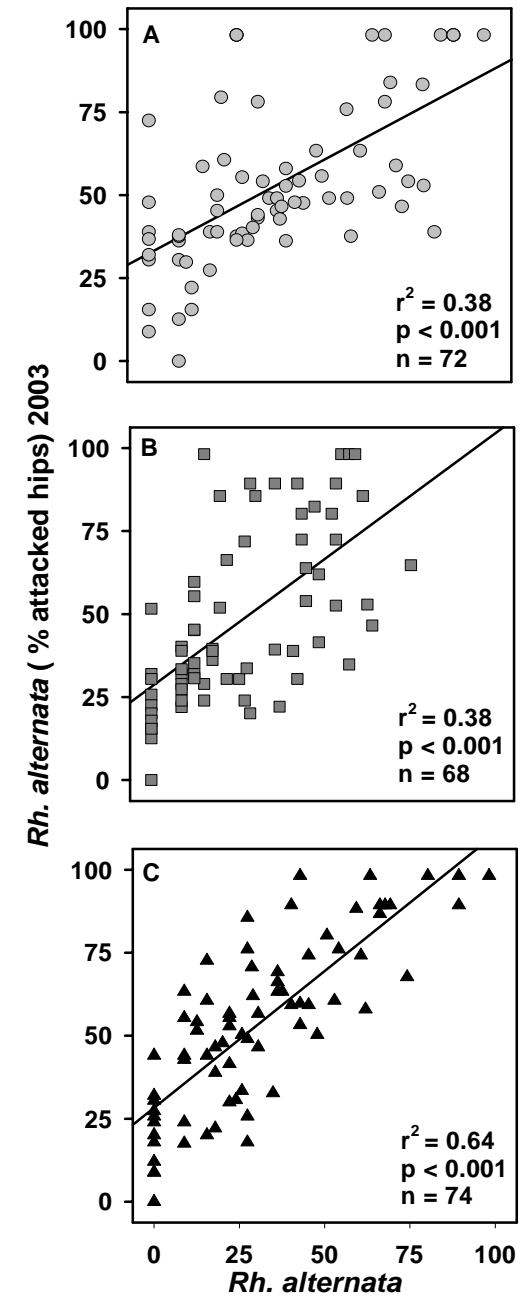

(\% attacked hips) 2002
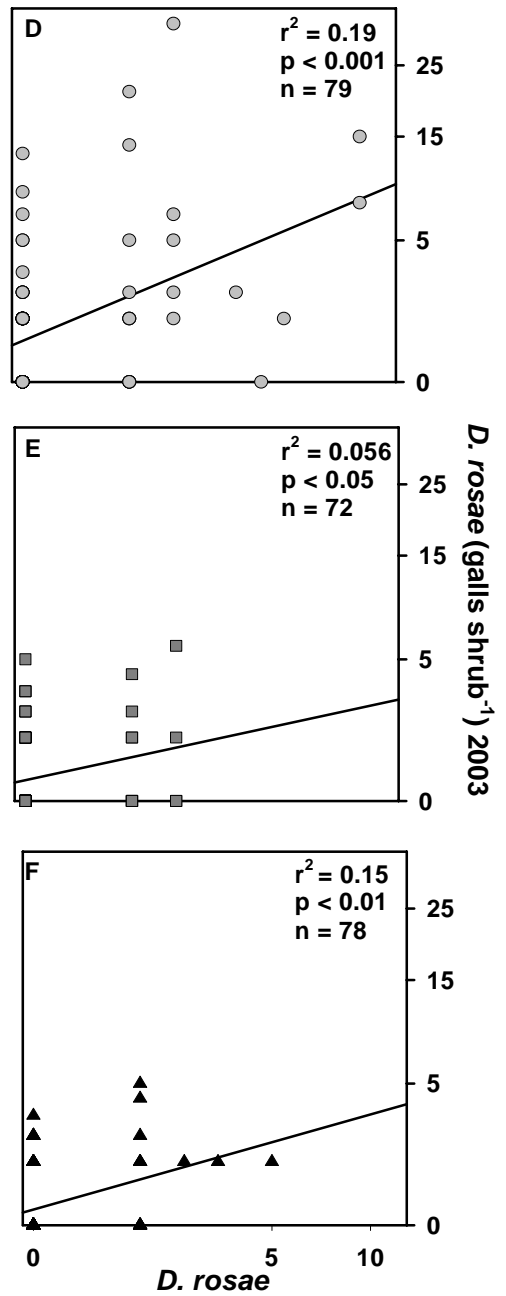

(galls shrub ${ }^{-1}$ ) 2002

Fig. 3. Regressions across shrubs between densities in 2002 and 2003 (densities are raw means per sampled shrubs) for Rhagoletis alternata (A: for the host Rosa rubiginosa; B: R. corymbifera; C: R. canina) and Diplolepis rosae (D: for the host $R$. rubiginosa; E: R. corymbifera; F: R. canina).

\section{Discussion}

The three investigated rose consumers showed significant differences in their densities between rose species. The variance accounted for by the host plant species ranked from $1 \%$ (Rh. alternata) to $9 \%$ (D. rosae) and 31\% (Phragmidium spp.). In contrast, variance accounted for by sites ranked in the opposite way ( $64 \%$ for Rh. alternata, 12\% for D. rosae and $9 \%$ for Phragmidium spp.), but the relative variance components are not independent from each other. Rh. alternata and D. rosae had the 
highest densities on the odorant $R$. rubiginosa, while Phragmidium spp. was most abundant on the glabrous $R$. canina. Only Phragmidium spp. affected the plant performance in the following year after consumer attack, resulting in decrease of the hip density in $R$. rubiginosa and of the leaf cover in R. canina.

Despite high densities, Rh. alternata had little impact on the sexual reproduction of roses and consequently on the fitness of the hosts (Bauer, 1998). Thus, the Rosa - Rh. alternata system is an example of a non-interactive system. Even when larvae attacked all hips of a shrub, we did not find a negative impact of Rh. alternata densities on reproduction and leaf cover in the following year. Furthermore, Rh. alternata density patterns across years were highly predictable. Host plants with a high attack in one year showed also a high attack in the following year. Attack of an herbivore with impact on the fitness of the host is expected to suffer from induced host responses such as toxic secondary compounds. However, the roses produce the hypanthium to attract seed disperser and the production of deterrents in response to Rh. alternata may not only affect this herbivore but also the legitimate seed disperser. Unpredictable hip production would be another strategy. Long-lived plants such as oaks use secondary compounds against seed predators (Silvertown, 1980). Roses are also long-lived and we interpret the predictable fruit production as further evidence that larvae of Rh. alternata have overall little impact on the fitness of roses.

In contrast, our data demonstrate clear differences between geographical locations. Two suites of factors may account for these differences: genetic and ecological factors. Genetic variation in Rh. alternata may trigger variation in density, but our population genetic studies using allozymes revealed little genetic differentiation across the same geographic gradient (Vaupel et al., submitted). Possible other factors are plant phenology (Hodkinson, 1997) and abundance of natural enemies (Koptur, 1985). The phenology of plants depends on the climate and if phenology influences the density of Rh.alternata one would expect geographical clines in density. Our data show no general decrease or increase in density with combined geographic distance (but see Fig. 2), although Rh. alternata reaches its range limit in the north of Germany (Smith and Bush, 2001). Brown (1984) suggested that the density should decrease towards the border of a species distributional range (central-marginal-model; e.g. Brussard, 1984; Hengeveld and Haeck, 1982; Sargarin and Gaines, 2002). This idea is not supported by our findings. Similarly, the density of D. rosae and Phragmidium spp. exhibited variations between sites across the geographical gradient, but we found little evidence of general geographical trends. 
In contrast to Rh. alternata, the gall-forming Diplolepis rosae manipulates the physiology of the rose shrubs to produce the gall and gall tissue (Bronner, 1992; Bayer, 1992; Bagatto et al., 1996; Harper et al., 2004). Although significant top-down effects of gall wasps on the population dynamics of the hosts seem to be rare (e.g. Stone et al., 2002), there is evidence that high cynipid densities can negatively affect host plant growth (e.g. Crawley and Long, 1995; Kato and Hijii, 1997). D. rosae preferred R. rubiginosa and 9\% of variation in density was explained by the factor host species. Due to the low density of $D$. rosae galls, with a mean density of 0.17 galls per shrub, the roses did not show defensive responses. The density of hips as well as leaf cover was independent of the number of galls in the previous year, so the density variation was predictable across years. Geyer (1988) and also Schröder (1967) report much higher gall densities. If wasp populations occasionally reach high densities, there may be significant fitness consequences for the host (Schröder, 1967). The manipulation of host physiology and the importance of host plant identity for the performance of $D$. rosae suggest that the relationships between $D$. rosae and the rose species may be considered intermediate between an interactive and a non-interactive system. D. rosae shows a clear preference for $R$. rubiginosa, the rose species with the glandular trichomes on the lower leaf surface. Also Schröder (1967) has recorded D. rosae most frequently from R. rubiginosa, but also from R. canina. A large number of parasitic wasp species are associated with the D. rosae gall (Mani, 1964). Trichomes on leaf surface, like the one on R. rubiginosa, can strongly affect insect-plant interactions, often being considered part of plant defence against herbivores (Juniper and Southwood, 1986), but sometimes also being beneficial for consumers (Eisner et al. 1998). The chemical blend of the glandular trichomes on $R$. rubiginosa may deter parasitoids and thus $R$. rubiginosa provide an enemy free space for D. rosae.

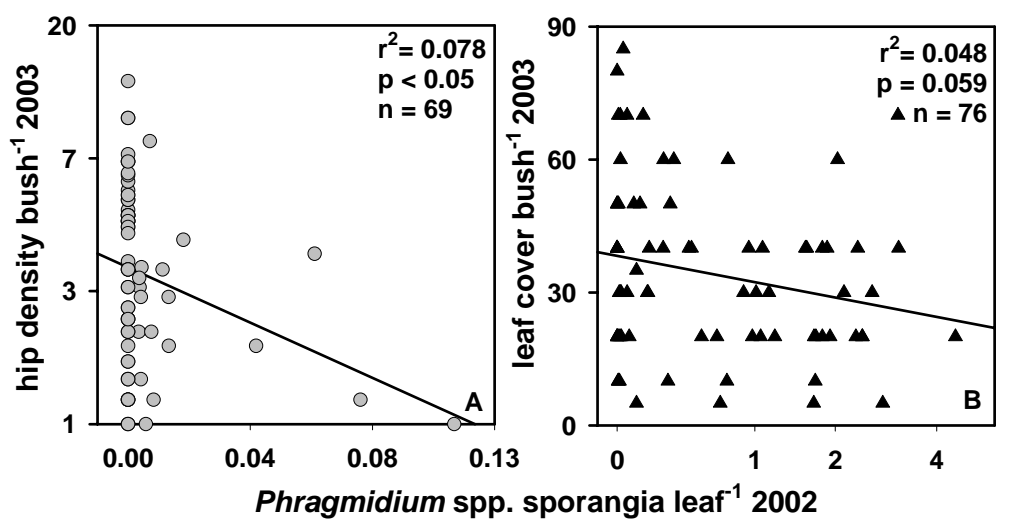

Fig.4. Regression across density of Phragmidium spp. in 2002 between (A) mean leaf cover per shrub in 2003 for the host species Rosa canina, and (B) mean hip density per shrub in 2003 for the host species R. rubiginosa. Each point refers to raw means per sampled shrub. 
Phragmidium spp. also showed significant density differences between the three rose species. The fungi preferred $R$. canina and $31 \%$ of variation in density is explained by the factor host plant species. Furthermore we found a marginally significant negative correlation between the density of Phragmidium spp. and leaf cover during the following year for the preferred R. canina. We found also a significant negative correlation between Phragmidium spp. and the hip density in the following year for R. rubiginosa, the host plant with the lowest rust infection. Shattock and Rahbar Bhatti (1983) found also on roses that rust infection with P. mucronatum produced early defoliation, a reduction in shoot number, length and fresh weight of shoots, flower number, hip production and root growth. Our results hint at a very close linkage between the infected host plant species and Phragmidium spp.. The relationships between Phragmidium spp. and the rose species are likely to be "interactive". Genetic studies found that the two Phragmidium species infected the three sampled rose species (Ritz et al., 2005). The density was lowest on $R$. rubiginosa, the rose species with glandular trichomes on the lower leaf surface. Valkama et al. (2005) pointed out that glandular trichomes might have evolved as a strategy against rust fungi. Bahçecioğlu and Yildiz (2005) argue that trichomes on the lower leaf surface hinder the entry of fungal germination tubes via the stomata. This would explain why trichomes occur only on the lower leaf surface. Furthermore, sesquiterpenes, which are known to occur in the trichomes of R. rugosa (Hashidoko, 1996) and also in R. rubiginosa (own unpublished data), inhibit the growth of fungi (e.g. Alvarez-Castellanos et al., 2001; Cakir et al., 2004).

Table 2 Qualitative summary of density patterns across three rose species and three consumer species ranked from non-interactive to interactive host-consumer interactions, with the inter-annual predictability of the consumer and their impact on plant performance on the host plant species. Density: Rhagoletis alternata $=\%$ attacked hips/shrub; Diplolepis rosae: galls/shrub; Phragmidium spp.= sporangia/leaflet. Host effect $(\%)=$ percentage of variance explained by the factor host species.

\begin{tabular}{lllllll}
\hline consumer & $\begin{array}{l}\text { type of } \\
\text { relationship }\end{array}$ & density & preferred host & $\begin{array}{l}\text { host effect } \\
(\%)\end{array}$ & $\begin{array}{l}\text { impact on plant } \\
\text { performance }\end{array}$ & $\begin{array}{l}\text { inter-annual } \\
\text { predictability }\end{array}$ \\
\hline Rh. alternata & $\begin{array}{l}\text { non- } \\
\text { interactive }\end{array}$ & high $(40 \%)$ & R. rubiginosa & 1 & no & $\begin{array}{l}\text { high } \\
(38-64 \%)\end{array}$ \\
$\begin{array}{lllll}\text { D. rosae } \\
\text { intermediate }\end{array}$ & low (0.16) & R. rubiginosa & 9 & no & $\begin{array}{l}\text { low } \\
(7-19 \%)\end{array}$ \\
Phragmidium spp. & interactive & high (1.24) & R.canina & 31 & yes & (no data) \\
\hline
\end{tabular}

In conclusion, the three endophytic consumers show differences in their density across host plant species and geographical location (Table 2). The relative amount of variance accounted for by host plant species increased from Rh.alternata (1\%) to D. rosae (9\%) and Phragmidium spp. (31\%). The importance of geography for density ranked opposite. These differences in densities could be related to interaction type of the consumer-host relationship, 
contrasting interactive with non-interactive systems. Little host-plant specialisation in Rh. alternata was linked to little impact on host performance despite high densities, whereas the high specialisation of Phragmidium spp. was related to high impact on the host. The density of Rh. alternata varied mainly in response to environmental factors. D. rosae galls showed intermediate patterns. While gall density differed between host plant species, the host impact was low, probably due to the low gall density. Phragmidium spp. and D. rosae seem to be influenced by the presence and absence of glandular trichomes. In interactive systems consumer species should evolve specific adaptations to particular host plant species, which in turn lead to some kind of host responses, resulting in density differences between host plant species. In contrast non-interactive systems should show little host specialisation, with low interaction of host plant and environment. Our data show that categorisation of consumer systems into interactive and non-interactive provides a possibility to predict patterns of density across host species and space.

Acknowledgements We are grateful to Christiane M. Ritz, Roman Fricke, Andrea Vaupel and Melanie Klose for help during the data sampling and Tatyana Rand for constructive comments on the manuscript. Financial support came from the German Science Foundation (Deutsche Forschungsgemeinschaft).

\section{References}

Adler, H., 1877. Beiträge zur Naturgeschichte der Cynipiden. Dt. Ent. Z. 21, 209-248.

Alvarez-Castellanos, P.P., Bishop, C.D., Pasqual-Villalobos, M.J., 2001. Antifungal activity of the essential oil of flowerheads of garland chrysanthemum (Chrysanthemum coronarium) against agricultural pathogens. Phytochemistry 57, 99-102.

Bagatto, G., Paquette, C., Shorthouse, J.D., 1996. Influence of galls of Phanacis taraxaci on carbon partitioning within common dandelion, Taraxacum officinale. Entomol. Exp. Appl. 79, 111-117.

Bahçecioğlu, Z., Yildiz, B., 2005. A study on the microfungi of Sivas Province. Turk. J. Bot. 29, 23-44.

Bauer, G., 1986. Life history strategy of Rhagoletis alternata (Diptera:Tephritidae), a fruit fly operating in a "non-interactive" system. J. Anim. Ecol. 55, 785-794.

Bauer, G., 1998. Structure and function of a non-interactive insect-plant system. Oecologia 115, 154-160. 
Bayer, M.H., 1992. Biochemical modification of the phenotype in cynipid galls. In: Williams, M.A.J., (Ed.) Plant Galls: Organisms, Interactions, Population. Clarendon Press, Oxford. pp. 429-446.

Bronner, R., 1992. The role of nutritive cells in the nutrition of cynipids and cecidomyiids. In: Shorthouse, J.D., Rohfritsch, O. (Eds.) Biology of Insect-Induced Galls. Oxford University Press, New York, pp. 118-140.

Brown, J.H., 1984. On the relationship between abundance and distribution of species. Am. Nat. 124, 255-279.

Brown, C., Mosteller, F., 1991. Components of variance. In: Hoaglin, D.C., Mosteller, F., Tukey, J.W. (Eds.) Fundamentals of exploratory analysis of variance. Wiley, New York, pp. 59-84.

Brussard, P.F., 1984. Geographic patterns and environmental gradients: the central-marginal model in Drosophila revisited. Annu. Rev. Ecol. Syst. 15, 25-64.

Bruzzese, E., Hasan, S., 1986. Collection and selection in Europe of isolates Phragmidium violaceum (Uredinales) pathogenetic to species of European blackberry naturalized in Australia. Ann. Appl. Biol. 108, 527-533.

Bush G.L., 1992. Host race formation and sympatric speciation in Rhagoletis fruit flies (Diptera: Tephritidae). Psyche 99, 335-357.

Cakir, A., Kordali, S., Zengin, H., Izumi, S., Hirata, T., 2004. Composition and antifungal activity of essential oils isolated from Hypericum hyssopifolium and Hypericum heterophyllum. Flavour Fragr. J. 19, 62-68.

Caughly, G., Lawton, J.H., 1981. Plant-herbivore systems. In: May, R.M. (Ed.) Theoretical Ecology. Blackwell Scientific Publications, Boston, pp. 132-66.

Crawley, M.J., Long, C.R., 1995. Alternate bearing, predator satiation and seedling recruitment in Quercus robur. J. Ecol. 83, 683-696.

Da Costa, C.P., Jones, C.M., 1971. Cucumber beetle resistance and mite susceptibility controlled by bitter gene in Cucumis sativus L.. Science 172, 1145-1146.

Denno, R.F., McClure, M.S., 1983. Variable plants and herbivores in natural and managed systems. Academic Press, New York.

Ehrlich, P.R., Raven, H., 1964. Butterflies and Plants: a study in coevolution. Evolution 18, 586-608.

Eisner, T., Eisner, M., Hoebeke, E.R., 1998. When defence backfires: Detrimental effect of a plant's protective trichomes on an insect beneficial to the plant. Proc. Natl. Acad. Sci. USA 95, 4410-4414. 
Evans, K.J., Jones, M.K., Roush, R.T., 2005. Susceptibility of invasive taxa of European blackberry to rust disease caused by the uredinial stage of Phragmidium violaceum under field conditions in Australia. Plant Pathol. 54, 275-286.

Geyer, A., 1988. Verinselungseffekt an der Entomofaune der Heckenrose (Rosa canina L.). Diploma-thesis, University Bayreuth.

Harper, L.J., Schönrogge, K., Lim, K.Y., Francis, P., Lichtenstein, C.P., 2004. Cynipid galls: insect-induced modifications of plant development create novel plant organs. Plant, Cell and Environment 27, 327-335.

Harris, P., 1973. Insects in the population dynamics of plants. Symposium of the Royal Entomological Society of London 6, 201-209.

Harrison, J.W.H., 1922. The egglaying instincts of Rhodites rosae and certain deductions there from. The Vasculum 8, 33-37.

Hashidoko, Y., 1996. The phytochemistry of Rosa rugosa. Phytochemistry 43, 535-549.

Hengeveld, R., Haeck, J., 1982. The distribution of abundance. 1. Measurements. J. Biogeogr. 9, 303-316.

Hilker, M., Rohfritsch, O., Meiners, T., 2002. The plant's response towards insect egg deposition. In: Hilkers, M., Meiners, T. (Eds.) Chemoecology of insect eggs and egg deposition. Blackwell Scientific Publications, Berlin, pp. 205-233.

Hodkinson, I.D., 1997. Progressive restriction of host plant exploitation along a climatic gradient: the willow psyllid Cacopsylla groenlandica in Greenland. Ecol. Entomol. 22, 47-54.

Hoffmann, G.M., Nienhaus, F., Schönbeck, F., Weltzien, H.C., Wilbert, H., 1985. Lehrbuch der Phytomedizin. P. Parey, Hamburg.

Johnson, M.T.J., Agrawal, A.A., 2005. Plant genotype and environment interact to shape a diverse arthropod community on Evening Primerose (Oenothera biennis). Ecology 86, 874-885.

Juniper, B.E., Southwood, T.R.E., 1986. Insects and the plant surface. Edward Arnold (Publisher) Ltd., London.

Karban, R., 1987. Effects of clonal variation of the host plant, interspecific competition, and climate on the population size of folivorous thrips. Oecologia 74, 298-303.

Karban, R., 1992. Plant variation: its effect on populations of herbivorous insets. In: Fritz, R.S., Simms, E.L (Eds.) Plant resistance to herbivores and pathogens: ecology, evolution, and genetic. University of Chicago Press, Chicago, pp. 195-215. 
Kato, K., Hijii, N., 1997. Effects of gall formation by Dryocosmus kuriphilus Yasumatsu (Hym., Cynipidae) on the growth of chestnut trees. J. Appl. Emtomol. 121, 9-15.

Koptur, S., 1985. Alternative defence against herbivores in Inga (Fabaceae: Mimosidae) over an elevational gradient. Ecology 66, 1629-1650.

Mani, M.S., 1964. Ecology of plant galls. The Hague, The Netherlands: Dr. W. Junk.

Minchinton, T.E., Ross, P.M., 1999. Oysters as habitats for limpers in a temperate mangrove forest. Austral. J. Eol. 24, 157-170.

Monro, J. 1967. The exploitation and conservation of resources by populations of insects. J. Anim. Ecol. 36, 531-547.

Pigott, J.P., Weiss, J., Evans, K.J., Mahr, F., 2003. Predicting the effect of the rust disease (Phragmidium violaceum (Shultz) Winter) on blackberry (Rubus fruticosus L. agg) in Victoria (Australia). In: Brundu, G., Brock, J., Camarda, I., Child, L., Wade, M. (Eds.) Plant invasion: Species Ecology and Ecosystem Management. Blackhuys Publishers, Leiden, pp.373-381.

Quinn, G.P., Keough, M.J., 2002. Experimental design and data analysis for biologists. Cambridge University Press, Cambridge.

Redfern, M., Askew, R.R., 1992. Plant galls. The Richmond Publishing Co. Ltd., Slough.

Ritz, C.M., Maier, W.F.A., Oberwinkler, F., Wissemann, V., 2005. Different evolutionary histories of two Phragmidium species infecting the same dog rose hosts. Mycol. Res. 109, 603-609.

Sargarin, R.D., Gaines, S.D. 2002. The 'abundant centre' distribution: to what extend is it a biogeographical rule? Ecol. Lett. 5, 137-147.

Savile, D.B.O., 1979. Fungi as aids in higher plant classification. Bot. Rev. 45, 377-503.

Schluter, D., 2000. The ecology of adaptive radiation. Oxford University Press, New York.

Schröder, D., 1967. Diplolepis (=Rhodites) rosae (L.) (Hym.: Cynipidae) and a review of its parasite complex in Europe. Tech. Bull. 9 Commonwealth Inst. of Biol. Control, 93131.

Searle, S.R., 1993. Unbalanced data and cell means models. In: Edwards, L.K. (Ed.) Applied analysis of variance in behavioural science. Marcel Dekker, New York, pp. 375-420.

Service, P., 1984. Genotypic interactions in an aphid-host plant relationship: Uroleucon rudbeckiae and Rudbeckia laciniata. Oecologia 61, 271-276.

Shattock, P.C., Rahbar Bhatti, M.H., 1983. The effect of Phragmidium mucronatum on rose understocks and maiden bush roses. Plant Pathol. 32, 61-66. 
Shorthouse, J.D., Wool, D., Raman, A., 2005. Gall-inducing insects - Nature's most sophisticated herbivores. Basic Appl. Ecol. 6, 407-411.

Smith, J.J., Bush, G.L., 2001. Phylogeny of the subtribe Carpomyin (Trypetinae), emphasizing relationship of the genus Rhagoletis. In: Aluja, M., Norrbom A.L. (Eds.) Fruit Flies (Tephritidae): Phylogeny and evolution of behavior. CRC Press LLC, New York, pp.187-217.

Silvertown, J.W., 1980. The evolutionary ecology of mast seedling in trees. Biol. J. Linn. Soc. $14,235-250$.

Stille, B., 1984. The effect of host plant and parasitoids on the reproductive success of the parthenogenetic gall wasp Diplolepis rosae (Hymenoptera, Cynipidae). Oecologia 63, 364-369.

Stone, G.N., Schönrogge, K., Atkinson, R.J., Belldio, D., Pujade-Villar, J., 2002. The population biology of oak gall wasps (Hymenoptera: Cynipidae). Annu. Rev. Entomol. 47, 633-668.

Strong, D.R., Lawton, J.H., Southwood, R., 1984. Insects on plants: Community patterns and mechanisms. Blackwell Scientific Publications, Oxford.

Sydow, P., Sydow, H., 1915. Monographia Uredinearum Vol.3. Gebrüder Borntraeger, Leipzig.

Timmermann, G., Müller, T., 1994. Wildrosen und Weißdorne Mitteleuropas Landschaftsgerechte Sträucher und Bäume. Verlag des Schwäbischen Albvereins e.V., Stuttgart.

Travis, J., 1996. The significance of geographical variation in species interactions. Am. Nat. $148,1-8$.

Underwood, N., Rausher, M.D., 2000. The effects of host-plant genotype on herbivore population dynamics. Ecology 81, 1565-1576.

Valkama, E., Koricheva, J., Salminen, J.P., Helander, M., Saloniemi, I. Saikkonen, K., Pihlaja, K., 2005. Leaf surface traits: overlooked determinants of birch resistance to herbivores and foliar micro-fungi? Trees 19, 191-197.

Wainhouse, D., Howell, R.S., 1983. Intraspecific variation in beech scale populations and in susceptibility of their host Fagus sylvaticus. Ecol. Entomol. 8, 351-359.

White, I., 1988. Tephritid flies (Handbooks for the identification of British insects 10, part 5a). Royal Entomol. Soc., London.

Williams, P. H., 1938. Investigations on the rust of roses, Phragmidium mucronatum. Ann. Appl. Biol. 25, 730-741. 
Wissemann, V., 2000. Epicuticular wax morphology and the taxonomy of Rosa (section Caninae, subsection Rubiginosae). Plant Syst. Evol. 221, 107-112.

Wissemann, V., Ritz, C.M., 2005. The genus Rosa (Rosoideae, Rosaceae) revisited: molecular analysis of nrITS-1 and atpB-rbcL intergenic spacer (IGS) versus conventional taxonomy. Bot. J. Linn. Soc. 147, 275-290.

Vaupel, A., Klinge, K., Brändle, M., Wissemann, V., Tscharntke, T., Brandl, R., submitted. Genetic differentiation between population of the European rose hip fly Rhagoletis alternata. Biol. J. Linn. Soc.. 


\title{
3 Does hybridisation of dog roses affect insect herbivory?
}

\begin{abstract}
Added herbivory of hybrid plants may stabilize species identity, but hybridization may also enhance diversification. In Rosa, section Caninae is characterised by the heterogamous "canina-meiosis", which generates offspring dominated by the genome of the mother. In this system, most plant traits, including the type of trichomes on the lower leaf surface are matroclinally inherited. Trichomes are supposed to influence insect herbivores. In the present study we test if hybridisation of dog roses (section Caninae) results in changes of palatability to insect herbivory. We analyzed the leaf consumption by a generalist herbivore Spodoptera littoralis (Lepidoptera: Noctuidae) on three sympatric dog rose species and their hybrids. Leaf consumption showed lower palatability of $R$. rubiginosa characterized by glandular trichomes and rose hybrids with $R$. rubiginosa as the maternal seed plant. There were no principal differences between hybrids and non-hybrids, but between rose phenotypes with and without glandular trichomes. Hence, we found no evidence that herbivores contribute to stabilization of rose species identity, but that the mother-based phenotype determines rose palatability. This opens a possibility for introgression of new hybridogenic genetic combinations into rose populations and is one basis for the diversity-generating potential of hybridization.
\end{abstract}

Keywords Glandular trichomes, matroclinal inheritance, leaf consumption, radiation process, palatability

\section{Introduction}

Natural hybridisation plays an important role in the evolution of plants (Anderson 1949, Stebbins 1959, Grant 1981, Wissemann 2005a, 2006). Hybridisation can result e.g. in incipient species, new genetic combinations, adaptations and loss of rare species (Gallez \& Gottlieb 1982, Arnold et al. 1991, Levin et al. 1996, Rhymer \& Simberloff 1996, Arnold 1997). The role of interspecific hybrids during evolution depends on fitness of hybrids compared to parental species (Arnold 1997, Burke \& Arnold 2001).

Hybridisation between host plants can influence the next trophic level by changing genetics and phenotypic traits (Karban 1992, Rieseberg 1995, Arnold 1997, Hochwender \& Fritz 2004). In plants, hybridisation can alter resistance to insect herbivory (Paige and Capman 1993, Fritz et al. 1994, 1998) and may change abundance of herbivorous insects (Karban 1992). The use of hybrid host plants by herbivores can cause five possible patterns (Fritz et al. 
1999). First, there can be no differences in herbivore use between hybrid plants and parents or second, the use can be intermediate between parents (additive hypothesis), third, greater (susceptible hypothesis) or fourth, less than on parents (resistant hypothesis) and fifth, similar to one parent (dominance hypothesis). All these possibilities have been intensively discussed in the recent literature, which address insect use of, and abundance on, hybrids plants vs. their parental species (Aguilar \& Boeckeln 1992, Fritz et al. 1994, Eisenbach 1996, Fritz et al. 1996, Orians \& Floyd 1997, Fritz et al. 1999). Herbivores can influence the evolution of plants in hybrid systems in three ways. They can cause differential survival in hybrid zones (Arnold 1997, Arnold et al. 1999), favour speciation of hybrid taxa (Rieseberg and Carney 1998) and support the introgression of traits between species (Stutz and Thomas 1964, Rieseberg and Brunsfeld 1992, Rieseberg \& Wendel 1993, Jiang et al. 2000). The influence of herbivores on hybrid zones depends on the herbivore use pattern. Increased herbivore load of hybrids may cause the extinction of hybrid populations and stabilize species identity (Arnold 1997, Arnold et al. 1999, Fritz et al. 1999).

Rosa is one of the plant genera (such as Salix, Quercus, and Aster) which is more predisposed to hybridisation than other genera (Ellstrand et al. 1996). In these genera spontaneous interspecific hybrids occur within 6-16\% (Ellstrand et al. 1996). Roses are supposed to have undergone rapid radiation since the last glacial period based on multiple hybridization events (Wissemann 2005b, Ritz et al. 2005). The dog roses (Rosa sect. Caninae (DC.) Ser.) form a complex of allopolyploids (Wissemann 2005b, Ritz et al. 2005), generating the gametes in a unique meiosis system (Täckholm 1920, 1922). In the meiotic system of most plant taxa the $\mathrm{F}_{1}$ hybrids have a complete haploid chromosome set from each parental species. Thus, additive, dominance, and overdominance are the main genetical processes which underpin the traits of the hybrids. In contrast, the section of the dog roses is characterised by the "caninameiosis" (Wissemann 2000a), which is a heterogamous system with haploid pollen grains and tetraploid egg cells (Blackburn and Harrison 1921, Täckholm 1920, 1922). Consequently the contribution of female and male genomes to the offspring is unequal. This reproduction system leads to a pronounced matroclinal inheritance. In a pentaploid dog rose $4 / 5$ of the nuclear genome is provided by the seed parent and only $1 / 5$ by the pollen parent (Ritz and Wissemann 2003, Wissemann and Hellwig 1997). Due to the matroclinal inheritance offspring and hybrids strongly resemble the seed parent (Wissemann 2000b).

Here we present experimental data about the palatability of species and reciprocal hybrids of three dog rose species. We focussed on three closely related dog rose species which differ in their phenotypes. Rosa canina L. is a glabrous rose. R. corymbifera Borkh. is a hairy, 
tomentose rose. $R$. rubiginosa L. is a rose species with glandular trichomes on the lower leaf surface. The complex inheritance of the dog rose system leads to an enormous phenotypic plasticity with most characters being inherited matroclinally, which is also true for the type of trichomes on the lower leaf surface (Wissemann 2000b). Due to the characters of the three rose species and the maternal inheritance (Wissemann 2000b) the palatability of the hybrids should be similar to the mother plant. We posed the following question. Does herbivory differ between hybrids and non-hybrids or do matroclinally inherited traits determine the palatability of the rose species and their hybrids?

\section{Methods}

We investigated the shrubs from the crossing experiments of Wissemann and Hellwig (1997). The original wild plant material used in these crossing experiments was selected from four localities around Göttingen (Lower Saxony, Germany), while the hybrids were generated experimentally. Pollen was gathered shortly before anthesis by excising the discus with anthers attached. Anthers and the pollen were used following the method of Fagerlind (1944). The crossing experiments were carried out in 1996. 139 of the generated plants were randomly planted in the Botanical Garden of the Georg-August-University of Göttingen in 2002. We focused on three dog-rose species. The hybrids had traits similar to their seed parents (Table 1). Altogether we have nine different phenotypes.

Table 1 Basic information about the rose species and hybrids used in the feeding experiment. n: number of tested rose shrubs per species; $\mathrm{x}=$ with traits (hairy, glandular, glabrous), $-=$ without traits.

\begin{tabular}{llllll}
\hline Rose species & Code & Glandular & Hairy & Glabrous & $\mathrm{n}$ \\
\hline R. rubiginosa & 1 & $\mathrm{x}$ & - & - & 10 \\
R. corymbifera & 2 & - & $\mathrm{x}$ & - & 10 \\
R. canina & 3 & - & - & $\mathrm{x}$ & 10 \\
R. rubiginosa x R. corymbifera & 4 & $\mathrm{x}$ & - & - & 3 \\
R. rubiginosa x R. canina & 5 & $\mathrm{x}$ & - & - & 2 \\
R. corymbifera x R. rubiginosa & 6 & - & $\mathrm{x}$ & - & 6 \\
R. corymbifera x R. canina & 7 & - & $\mathrm{x}$ & - & 4 \\
R. canina x R. rubiginosa & 8 & - & - & $\mathrm{x}$ & 10 \\
R. canina $\mathrm{x}$ R. corymbifera & 9 & - & - & $\mathrm{x}$ & 9 \\
\hline
\end{tabular}

To obtain a general measure of plant palatability we used larvae of Spodoptera littoralis [Boisduval], (Lepidoptera: Noctuidae), a well-known, polyphagous herbivore, frequently used in laboratory investigations. Eggs of the moth were obtained from a laboratory stock of the 
Bayer AG. The eggs and the larvae were kept in a climate chamber with a photoperiod of L/D 12/12, 70\% atmospheric humidity and a temperature of $27^{\circ} \mathrm{C}$. Artificial food, a mix of water, agar, bean flour, barm, ascorbic acid, cholesterol, sorbic acid, hydroxyl benzoate, streptomycin, formaldehyde and germ oil, was provided from the first larval phase on.

We performed three series of feeding tests, one in May, in June and in July 2003. Fully expanded non-senescing leaves from the tip of branches and of similar shrub height were collected from every shrub. In every experiment, we used leaves from different branches to avoid possible confounding effects of induced plant defence. Leaves were moistened with deionised water to keep them turgescent and were stored at $3{ }^{\circ} \mathrm{C}$ in sealed polythene bags for 4 hours. The utmost leaflet of the pinnate leaves were weighed and placed in a petri dish $(\varnothing 9 \mathrm{~cm})$ together with one larvae (8 days old) on slightly with deionised water moistened filter paper. Prior to the experiment each larvae was weighed. Five leaflets per shrub were weighed and dried to estimate the initial dry mass. We used ten shrubs for each plant species and five leaflets per shrub. The test ran for 24 hours in the climate chamber $\left(27^{\circ} \mathrm{C}\right.$ and $12 \mathrm{~h}$ light). The remaining leaf material was dried and weighed. Leaf consumption was expressed as mg consumed leaf dry mass in $24 \mathrm{~h}$.

Leaf water, nitrogen and carbon contents are closely related to functional leaf traits and to palatability (Schädler et al. 2003). Therefore, we measured these traits for each bush used during the feeding experiment. Leaf water was determined by the ratio of leaf dry mass (drying leaflets to weight constancy at $60^{\circ} \mathrm{C}$ ) to fresh mass from five leaflets of each shrub. To estimate the carbon/nitrogen-ratio we collected a sample of leaves from the tip of branches of every shrub and from the same height we took the leaves for the experiments. Leaves were dried at $60^{\circ} \mathrm{C}$ for 48 hours, milled with a high-speed rotor mill and total nitrogen- and carbon content was measured with a CNS-2000 analyser (LECO Instruments, St. Joseph, Michigan USA).

Data analyses were performed using Statistica 6.1. For the analysis of leaf consumption we took the average of 5 leaflets per shrub and for the larval fresh weight the average of 5 larvae per shrub. Prior to any statistical analysis contents of nitrogen were arcsin-transformed and the specific water content were log-transformed to reduce heterogeneity of variance and to adjust the data to normal distribution. For content of carbon, C/N-ratio, larval fresh weight and leaf consumption we used the raw data.

We correlate the variables nitrogen and carbon content, the $\mathrm{C} / \mathrm{N}$-ratio, the specific water content and the larval fresh weight (mean over five larvae for each shrub) with the Spodoptera 
leaf consumption (mean over five leaflets for each shrub) in simple regressions. Variables with significant correlations were used in the subsequent analyses as covariables (Table 2).

Table 2 Correlations ( $\mathrm{r}^{2}$-values) of the leaf consumption consumed by herbivores with the variables nitrogen, carbon and specific water content and carbon/nitrogen- ratio of leaves and the larval fresh weight over three month of experiments and over all three months together, ${ }^{*} P<0.05, * * P<0.01, * * * P<0.001$.

\begin{tabular}{lllll}
\hline & Month 1 & Month 2 & Month 3 & All \\
\hline Nitrogen content & 0.0046 & 0.0038 & 0.0017 & 0.0021 \\
Carbon content & 0.12 & 0.0069 & 0.0080 & 0.020 \\
Carbon/nitrogen-ratio & 0.0024 & 0.0000 & 0.089 & 0.00014 \\
Water content & $0.15 * *$ & $0.21 * * *$ & $0.19 * * *$ & $0.097 * * *$ \\
Larval fresh weight & $0.092 *$ & $0.20 * * *$ & 0.032 & $0.12 * * *$ \\
\hline
\end{tabular}

We designed a Split-Plot-Model ANCOVA with the leaf consumption as response variable in relation to the two categorical factors (month of experiment and rose genotype) and the covariables fresh weight of larvae and specific water content. The sum of squares were calculated sequentially (Type I), resulting in a stepwise test of effects according to the order of variables included. We used planned comparisons to test for differences between groups of rose species and hybrids (glandular, hairy or glabrous rose species).

Table 3 Effect of rose species ( $R$. canina, R. corymbifera and R. rubiginosa) and their hybrids on the Spodoptera leaf consumption after accounting for differences in larval fresh weight and leaf water content. Split-plot model ANOVA analyses; $\mathrm{SS}=$ sum of square, $\mathrm{df}=$ degrees of freedom and F-ratio; ${ }^{*} P<0.05, * * P<0.01, * * * P<0.001$.

\begin{tabular}{llll}
\hline & SS & df & F \\
\hline Larval fresh weight & 170.31 & 1 & $39.50^{* * *}$ \\
Water content & 176.62 & 1 & $40.96^{* * *}$ \\
Month of exp. (M) & 123.04 & 2 & $14.27^{* * *}$ \\
Rose phenotype (RP) & 114.52 & 8 & $3.32^{* *}$ \\
M * RP & 104.17 & 16 & 1.51 \\
\hline
\end{tabular}

\section{Results}

We found significant differences in the leaf consumption between the three months and the rose species and their hybrids, but no significant interaction between rose genotype and month of experiment (Table 3). Mean leaf consumption across all bushes was $7.73 \pm 0.34 \mathrm{mg}$ in May, $5.62 \pm 0.23 \mathrm{mg}$ in June and $6.39 \pm 0.37 \mathrm{mg}$ in July. In the first month the differences of leaf consumption between the rose species was not as clear as in the second and third month (Fig. 1a-c), but the two hybrids with R. rubiginosa as mother plant showed lower leaf 
consumption compared to the other rose species and hybrids (Fig. 1a). In the second and third month the tendency of lower leaf consumption for $R$. rubiginosa and hybrids with $R$. rubiginosa as mother plant was more explicit. The range of leaf consumption of the different rose genotypes was similar. $R$. rubiginosa and all hybrids with $R$. rubiginosa as seed parent have the lowest palatability (Fig. $1 \mathrm{~b}+\mathrm{c}$ ). Higher palatability was found for R. canina and $R$. corymbifera and hybrids with these two rose species as mother plant.

The planned comparison showed significant differences for the leaf consumption between rose genotypes with and without glands on the lower leaf surface, but not between rose species and hybrids or hairy and glabrous rose genotypes (Table 4). The difference in leaf consumption between hairy and glandular rose genotypes was also significant. Glandular hybrids and glandular non hybrids showed a similar palatability.

Fig. 1. (a-c) Spodoptera leaf consumption across rose species and hybrids over three experimental months. Corrected means $\pm 1 \mathrm{SE}$ from the Split-Plot-Model ANCOVA in Table 3 (rose species: 1=R. rubiginosa, $2=R$. corymbifera, $\quad 3=R$. canina, $\quad 4=R$. rubiginosa $\quad \mathrm{x} \quad R$. corymbifera, $5=R$. rubiginosa $\mathrm{x} \quad R$. canina, $6=R$. corymbifera $\times$. rubiginosa, $7=R$. corymbifera $\times R$. canina, $8=R$. canina $\times R$. rubiginosa, $9=R$. canina $\mathrm{x}$ $R$. corymbifera, grey $=$ glandular phenotype, dark grey= hairy phenotype, black= glabrous phenotype, circles $=$ non-hybrid genotype, squares= hybrid genotype).
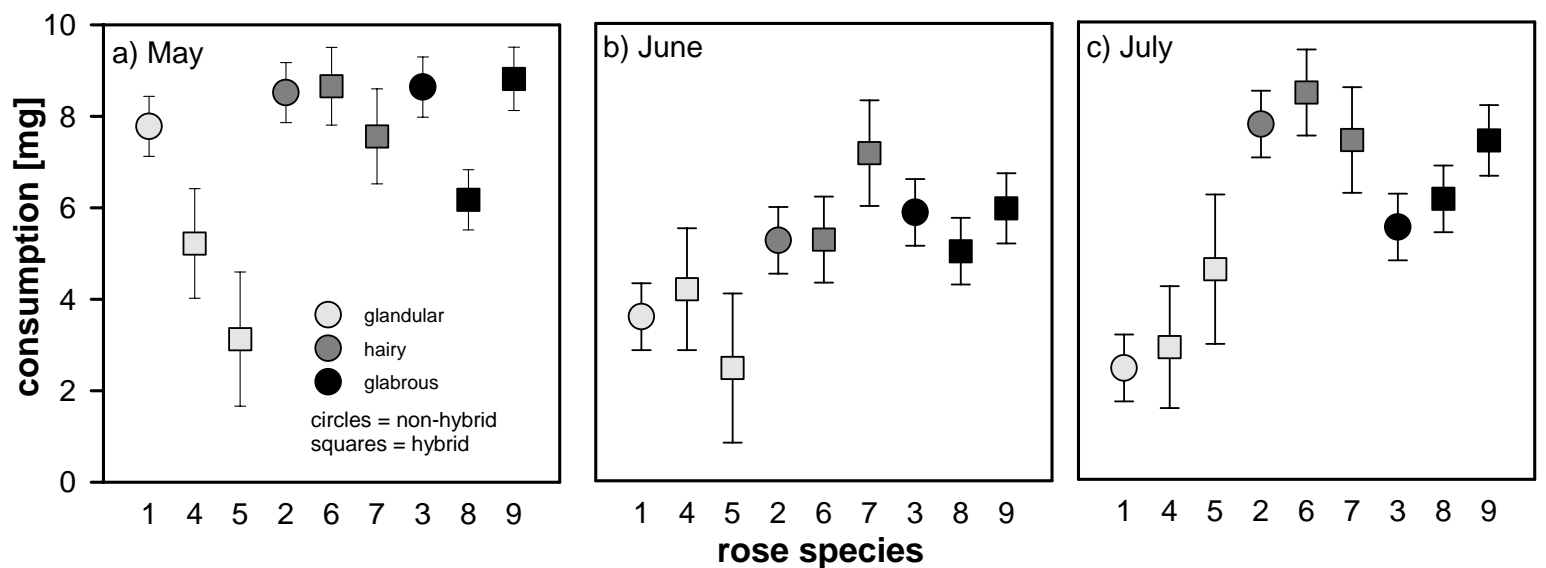

\section{Discussion}

The leaf consumption by the generalistic phytophage showed significant differences between rose species and hybrids. We found lowest palatability for $R$. rubiginosa and hybrids with R. rubiginosa as mother plant, particularly in the second and third month of our experiments. There were no significant differences between hybrids and non-hybrids, but between shrubs with glandular trichomes (rose species with the morphology of $R$. rubiginosa) and without glandular trichomes (rose species with the morphology of R. corymbifera and R. canina). Thereby the phenotype influenced palatability, which was transferred by maternal inheritance to the hybrids. We found no evidence that phytophages have the potential to stabilise identity 
of rose species in the wild. Moreover the matroclinally inherited traits, such as glandular trichomes, appeared to determine the palatability of the rose species.

Table 4 Differences in leaf consumption within different groups of rose geno- and phenotypes (hybrid, nonhybrid, glandular, hairy, glabrous). A priori comparisons with planned pairs of specific means of the Split-plot model ANOVA analyses. F-ratio; * $P<0.05,{ }^{* *} P<0.01$, *** $P<0.001$.

\begin{tabular}{ll}
\hline Rose genotype & $\mathrm{F}$ \\
\hline Hybrid vs. non hybrid & 0.221 \\
Glandular vs. non glandular & $8.52^{* *}$ \\
Hairy vs. glabrous & 0.27 \\
Hairy vs. glandular & $7.41^{* *}$ \\
Glandular hybrids vs. glandular non hybrids & 0.070 \\
\hline
\end{tabular}

All members of the subsection Rubigineae are characterised by a granule wax type with glandular trichomes (Wissemann 2000b). Studies on offspring of reciprocal crossings showed that the wax type is expressed by the maternal genome, which is also true for the type of trichomes on the lower leaf surface (Wissemann 2000b). From an ecological and evolutionary perspective, the plant surface is an important factor influencing host selection by phytophagous insects (Chapman 1977). In general, trichomes can strongly affect insect-plant interaction and trichomes are often considered as an important component of the defence against herbivores (Juniper and Southwood 1986). Trichomes may reduce leaf palatability (Haddad and Hicks 2000). The secondary compounds in the glandular trichomes of the rose species $R$. rubiginosa possibly act as deterrent against herbivory. The glandular trichomes of $R$. rubiginosa and also of their hybrids are rich in secondary metabolites belonging to the sesquiterpene group (Klinge, unpublished data). Hashidoko (1996) found also sesquiterpenes in the trichomes of Rosa rugosa (Sect. Cinnamomeae) and their hybrids. Frelichowski and Juvik (2001) found that sesquiterpene carboxylic acids produced in glandular trichomes from a wild tomato species affect the larval feeding behaviour and survival of Spodoptera exigua (Lepidoptera: Noctuidae). Also Eigenbrode et al. (1996) found such results with the reaction of Spodoptera exigua on sesquiterpenoids, but on two accessions of cultivar tomato plants. Simpler sesquiterpenoids antifeedants, e.g. warburganal, have been isolated from the East African trees Warburgia stuhlmannii and W. ugandensis and showed activity against larvae of Spodoptera littoralis (Kubo et al. 1976).

The non-glandular type of trichomes on R. corymbifera and hybrids with $R$. corymbifera as seed parent showed no effect on the leaf consumption (see Table 4). The rose phenotypes with non-glandular trichomes are palatable as the glabrous rose phenotypes. Even though we 
showed the results of higher palatability of the rose species without glandular trichomes in comparison to the rose species with glandular trichomes, rose species without glandular trichomes are widely distributed and common in nature. Constitutive plant resistance is a constant level of plant resistance regardless to the intensity of herbivore attack (Underwood and Rausher 2002). Glandular trichomes are a type of constitutive plant defence. Dog rose leaves covered with glandular trichomes are also less palatable to other generalist feeders such as gastropoda (Keller 1931). There may be a trade-off between the constitutive plant defence of the glandular rose species and the non-glandular rose species. But there may be further strategies to reduce herbivory using deterrent substances, tolerating damage or compensatory growth (Herrera and Pellmeyer 2002).

Fritz et al. (1999) pointed out if parasites affect host fitness and if hybridization with a resistant host species produces resistant hybrids, then hybrid genotypes can be favoured in an introgressed population. The matroclinal inheritance generates in nature dog rose plants with different genotypes but conform phenotypes (Wissemann 2005b). Täckholm (1920, 1922) postulated the hybridogenic origin of dog roses, also suggested by Blackburn and Harrison (1921), Gustafsson (1944), Gustafsson and Hakansson (1942), and Hurst (1925, 1928) based on cytological observations. By genetic analyses Wissemann $(1999,2002)$ and Ritz et al. (2005) were able to verify the hypothesis of the allopolyploid origin of Rosa, section Caninae. Our results indicate that the hybridisation of rose species of the section Caninae is an example for the dominance hypothesis (hybrid similar to one parent; Fritz et al. 1999). In our investigation herbivores did not act as stabiliser of species. Apparently, herbivores differ for plant susceptibility in matroclinally inherited plant traits and gave thereby a possibility for introgression of new genotypes into rose populations. This is one basis for the diversitygenerating potential of hybridization stressed by Anderson (1949), Stebbins (1959), Grant (1981) and Wissemann (2005a, b, 2006). Recently hybridisation was shown to enable ecological transitions which allow for niche differentiation and subsequent radiation of hybridogenic species (Rieseberg et al. 2003). In the dog rose system this is different or at least not as explicit as in Helianthus species. Maternal inheritance of phenotypic characters due to heterogamous meiosis allows for evolution within the framework, the evolutionary constraints of the seed parents evolution. By that the maternal dominance of the genetic load within a hybrid does not facilitate ecological transitions as in sunflowers. Nevertheless, there is no evidence in Rosa that maternal dominance provides the base for negative or positive selection against or for hybrids compared to intraspecific out-crossing (Ritz \& Wissemann 2003). However, the combination of maternal dominance and non-mendelian inheritance allows for 
the control of hybrid radiation possibilities. Our results of maternally controlled character expression and the impact on herbivore palatability add new data on the important role of natural hybridisation as a diversification factor in the evolutionary history of plants.

Acknowledgements We are grateful to Heike Ruhnke for advice in the procedure of the experiments, to Martin Schädler and Roman Fricke for help with the analysis. We thank S.R. Gradstein who supports our studies by providing the fields for the experimental rose collection and the staff of the Botanical Garden Göttingen for their kind help and cooperation during this study. Financial support came from the German Science Foundation (Deutsche Forschungsgemeinschaft).

\section{References}

Aguilar JM, Boecklen WJ (1992) Patterns of herbivory in the Quercus grisea x Quercus gambelii species complex. Oikos 64:498-504

Anderson E (1949) Introgressive hybridization. Wiley, New York

Arnold ML (1997) Natural hybridization and evolution. Oxford University Press, New York

Arnold ML, Buckner CM, Robinson JJ (1991) Pollen mediated introgression and hybrid speciation in Louisiana irises. P Natl Acad Sci USA 88:1398-1402

Arnold ML, Bulger MR, Burke JM, Hempel AL, Williams JH (1999) Natural hybridization: how low can you go and still be important? Ecology 80:371-381

Blackburn K, Harrison JHW (1921) The status of the British rose forms as determined by their cytological behaviour. Ann Bot 35:159-188

Burke JM, Arnold ML (2001) Genetics and the fitness of hybrids. Annu Rev Genet 35:31-52

Chapman RF (1977) The role of the leaf surface in food selection by Acridids and other insects. Colloques Internationaux CNRS. Comportement des insects et milieu trophique 265: $133-148$

Eigenbrode SD, Trumble JT, White KK (1996) Trichome exudates and resistance to beet armyworm (Lepidoptera, Noctuidae) in Lycopersicon hirsutum f. typicum accessions. Popul Ecol 25 :90-95

Eisenbach J (1996) Three-trophic-level interactions in cattail hybrid zones. Oecologia $105: 258-265$

Ellstrand NC, Whitkus R, Rieseberg LH (1996) Distribution of spontaneous plant hybrids. Proc. Natl Acad Sci-Biol 93:5090-5093

Fagerlind F (1945) Die Bastarde der Canina-Rosen, ihre Syndese- und Formbildungsverhältnisse. Acta Horti Berg 14:7-37 
Frelichowski JE Jr., Juvik JA (2001) Sesquiterpene carboxylic acids from a wild tomato species affect larval feeding behaviour and survival of Helicoverpa zea and Spodoptera exigua (Lepidoptera: Noctuidae). J Econ Entomol 94:1249-1259

Fritz RS, Moulia C, Newcombe G (1999) Resistance of hybrid plants and animals to herbivores, pathogens, and parasites. Annu Rev Ecol Syst 30:565-591

Fritz RS, Nichols-Orians CM, Brunsfeld SJ (1994) Interspecific hybridization of plants and resistance to herbivores: hypotheses, genetics, and variable responses in a diverse herbivore community. Oecologia 97:106-117

Fritz RS, Roche BM, Brunsfeld SJ (1998) Genetic variation in resistance of hybrid willows to herbivores. Oikos 83:117-128

Fritz RS, Roche BM, Brunsfeld SJ, Orians CM (1996) Interspecific and temporal variation in herbivore responses to hybrid willows. Oecologia 108:121-129

Gallez GP, Gottlieb LD (1982) Genetic evidence for the hybrid origin of the diploid plant Stephanomeria diegensis. Evolution 36:1158-1167

Grant V (1981) Plant speciation. Colombia University Press, New York

Haddad NM Hicks WM (2000.). Host pubescence and the behaviour and performance of the butterfly Papilio troilus (Lepidoptera: Papilionidae). Environ Entomol 29:299-303

Harrison R (1993) Hybrid zones and the evolutionary process. Oxford University Press, New York.

Hashidoko Y (1996) The phytochemistry of Rosa rugosa. Phytochemistry 43:535-549

Hashidoko Y, Endoh K, Kudo T, Tahara S (2001) Capability of wild Rosa rugosa and its varieties and hybrids to produce sesquiterpene components in leaf glandular trichomes. Biosci Biotech Bioch 65:2037-2043

Herrera CM, Pellmyr O. (2002) Plant-animal interaction: an evolutionary approach. Blackwell Publishing, Oxford

Hochwender CG, Fritz RS (2004) Plant genetic differences influence herbivore community structure: evidence from a hybrid willow system. Oecologia 138:547-557

Jiang CX, Chee PW, Draye X, Morrell PL, Smith CW, Paterson AH (2000) Multilocus interactions restrict gene introgression in interspecific population of polyploidy Gossypium (cotton). Evolution 54:798-814

Juniper BE, Southwood TRE (1986) Insects and the Plant Surface. Edward Arnold (Publishers) Ltd., London 
Karban R (1992) Plant variation: its effects in populations of herbivorous insects. In: Fritz RS, Simms EL (eds) Plant resistance to herbivores and pathogens: ecology, evolution, and genetics. University of Chicago Press, Chicago, pp195-215.

Keller R (1931) Synopsis Rosarum spontanearum Europae mediae. Denkschr Schweiz Naturf Ges 65

Kubo I, Lee YW, Pettei M, Pilkiewicz F, Nakanishi K (1976) Potent army worm antifeedants from the East African Warburgia plants. Chem Commun 24:1013-1014

Levins DA, Francisco-Ortega J, Jansen RK (1996) Hybridization and the extinction of rare plant species. Biol Conserv 10:10-16

Orians CM, Floyd T (1997) The susceptibility of parental and hybrid willows to plant enemies under contrasting soil nutrient conditions. Oecologia 109:407-413

Paige KN, Chapman WC (1993) The effects of host-plant genotype, hybridization and environment on gall aphid attack and survival in cottonwood: the importance of genetic studies and the utility of FRLP's. Evolution 47:36-45

Ranger CM, Hower AA (2002) Glandular trichomes on perennial alfalfa affect host-selection behavior of Empoasca fabae. Ent Ex Appl 105:71-81

Rhymer JM, Simberloff D (1996) Extinction by hybridization and introgression. Annu Rev Ecol Evol S 27:83-109

Rieseberg LH (1995) The role of hybridization in evolution: old wine in new skins. Am J Bot 82:944-953

Rieseberg LH, Raymond O, Rosenthal DM, Lai Z, Livingstone K, Nakazato T, Durphy JL, Schwarzbach AE, Donovan LA, Lexer C (2003) Major ecological transitions in wild sunflowers facilitated by hybridization. Science 301:1211-1216.

Rieseberg LH, Brunsfeld SJ (1992) Molecular evidence and plant introgression. In: Soltis PS, Soltis DE, Doyle JD (eds) Molecular systematics of plants. Chapman and Hall, New York, pp 151-176

Rieseberg LH, Carney SE (1998) Plant hybridization. New Phytol 140:599-624

Rieseberg LH, Ellstrand NC (1993) What can molecular and morphological markers tell us about plant hybridization? Crit Rev Plant Sci 12:213-241

Rieseberg LH, Sinervo B, Linder CR, Ungerer MC, Arias DM (1996) Role of gene interaction in hybrid speciation: evidence from ancient and experimental hybrids. Science 272:741745 
Rieseberg LH, Wendel JF (1993) Introgression and its consequences in plants. In: Harrison RG (ed) Hybrid zones and the evolutionary process. Oxford University Press, New York, pp 70-109

Ritz CM, Schmuths H, Wissemann V (2005). Evolution by reticulation: European dogroses originated by multiple hybridization across the genus Rosa. J Hered 96:1-11

Ritz CM, Wissemann V (2003) Male correlated non-matroclinal character inheritance in reciprocal hybrids of Rosa section Caninae (DC.) SER. (Rosaceae). Plant Syst Evol 241:213-221

Schädler M, Jung G, Auge H, Brandl R (2003) Palatability, decomposition and insect herbivory: patterns in a successional old-field plant community. Oikos 103:121-132

Stebbins GL (1959) The role of hybridization in evolution. Proc Am Phil Soc 103:231-251

Stace CA (1987) Hybridization and the plant species. In: Urbanska, KM (ed) Differentiation patterns in higher plants. Acacemic press, New York, pp115-127

Stutz HC, Thomas LK (1964) Hybridization and introgression in Cowania and Purshia. Evolution 18:183-195

Täckholm G (1920) On the cytology of the genus Rosa. A preliminary note. Svensk Bot Tidskr 14:300-311

Täckholm G (1922) Zytologische Studien über die Gattung Rosa. Acta Horti Berg 7:97-381

Underwood N, Rausher M (2002) Comparing the consequences of induced and constitutive plant resistance for herbivore population dynamics. Am Nat 160:20-30

Wissemann V (1999) Genetic constitution of Rosa sect. Caninae (R. canina, R. jundzillii) and sect. Gallicanae (R. gallica). Angew Bot 73:191-196

Wissemann V (2000a) Molekulargenetische und morphologisch-anatomische Untersuchungen zur Evolution und Genomzusammensetzung von Wildrosen der Sektion Caninae (DC.) SER. Bot Jahrb Syst 122:357-429

Wissemann V (2000b) Epicuticular wax morphology and the taxonomy of Rosa (section Caninae, subsection Rubiginosae). Plant Syst Evol 221:107-112

Wissemann V (2002) Molecular evidence for allopolyploid origin of the Rosa canina complex (Rosaceae, Rosoideae). J Appl Bot 76:176-178

Wissemann V (2005a) Die Bedeutung von Hybridisierung als Evolutionsfaktor bei Pflanzen unter besonderer Berücksichtigung der Gattung Rosa L. (Rosaceae, Rosoideae). Habilitationsschrift Friedrich-Schiller-Universität Jena, 240 pages

Wissemann V (2005b) Evolution by hybridisation. The influence of reticulate evolution on biosymmetrical patterns and processes in plants. Theory Bioscienc 123:223-233 
Wissemann V (2006, in press) Evolution of plants by means of hybridisation. Systematics \& Biodiversity 4(4)

Wissemann V, Hellwig FH (1997) Reproduction and hybridisation in the genus Rosa section Caninae (Ser.) Rehd. Botanica Acta 110:251-256

Yencho GC Tingey WM (1994) Glandular trichomes of Solanum berthaultii alter host preference of the colorado potatoe beetle, Leptinotarsa decemlineata. Ent Ex Appl 70:217-225

Zvereva EL, Kozlov MV, Niemelä P (1998) Effects of leaf pubescence in Salix borealis on host-plant choice and feeding behaviour of the leaf beetle, Melanosoma lapponica. Ent Ex Appl 89:297-30 


\title{
4 Cynipid gall-parasitoid interactions, comparing three dog rose species along a geographic gradient
}

\begin{abstract}
Tritrophic interactions may greatly change with plant species and geographical context, but little is known about relative importance of each trophic level at different spatial scales. We tested how the associated parasitoid community of cynipid galls (Diplolepis rosae L.; Hym. Cynipidae) differed between three closely related rose species across a geographical gradient in Germany. The scented Rosa rubiginosa L. showed remarkably higher gall densities, than the glabrous Rosa canina L. and the hairy rose Rosa corymbifera L.. The survival rate of the gall-maker D. rosae was highest and the percent parasitism lowest on R. rubiginosa. Hence, this rose species appeared to provide an important refuge for the gall-maker population. The glabrous trichomes of $R$. rubiginosa and the correspondingly greatly smelling galls may have been the reason for the low parasitism, which was negatively density dependent. The percent parasitism was in all three rose species highest in small galls, presumably due to limiting length of the parasitoids ovipositor. Gall-parasitoid interactions did not change with geographical position. Percent of the parasitoid Glyphomerus stigma Fabr. (Hymenoptera, Torymidae) as well as total parasitism were similar at al spatial scales, host plant species, gall volume and geographical location. The other parasitoid species showed species-specific differences in host use, thereby contributing to the coexistence on this species-rich parasitoid community. In conclusion, these trophic interactions were driven by host plant identity, not geographical location, while highest gall densities were associated with lowest parasitism rates.
\end{abstract}

Keywords Cynipidae, food webs, enemy-free space, host-plant association, community structure

\section{Introduction}

Multitrophic interactions between host plant species, herbivores and natural enemies may change depending on the host plant species and geographical location (Hare, 1992, Hawkins, 1994, Fritz, 1992, 1995, Fritz et al., 1997, Harvey et al., 2003, Cattell \& Stiling, 2004). Plant traits may greatly differ between host plant species, including secondary compounds, plant architecture or nutritional value, and often affect the herbivores and their natural enemies (Fritz, 1995, Fritz et al., 1997, Hunter \& Price, 1992, Harvey et al., 2003). Further the 
community structure and trophic interactions may show inconsistency over a geographical gradient (Hawkins \& Mills, 1996, Tscharntke et al., 2001, Cattell \& Stiling, 2004). Local environmental conditions can influence herbivore numbers by altering the quality of the host plant or by altering the interaction between the herbivore and its natural enemies (Price \& Clancy, 1986, Stiling \& Rossi, 1997, Moon \& Stiling, 2000). Genetic differences among and within host plant taxa may be modified by environmental conditions, thereby altering herbivore-natural enemy interactions (Fritz et al., 1997). In general, studies on community structures on a geographic gradient can help to elucidate the processes structuring multitrophic interactions.

In this paper, we tested gall-parasitoid interactions across three dog rose species and across a geographical gradient in Germany. Plant galls and their inhabitants provide the opportunity to easily analyse tritrophic interactions (Price, 1987, Tscharntke, 1994). The gall-maker Diplolepis rosae L. (Hym. Cynipidae) is confined to the genus Rosa. In Europe, the conspicuous and multichambered galls have been found on several Rosa species (Schröder, 1967). In southern Sweden (Stille, 1984) and in England (Harrison, 1922) all species with D. rosae belong to the section Caninae. These galls are characterised by a complex community, described by Blair (1945). Besides the gall-maker D. rosae, the inquilin gall wasp, Periclistus brandtii R. (Hym. Cynipidae) and several parasitic wasps species can be found in the D. rosae gall (Mani, 1964, Redfern \& Askew, 1992). D. rosae gets parasitized by Orthopelma mediator Thunb. (Hym. Ichneumonidae), Torymus bedeguaris L. (Hym. Torymidae), Pteromalus bedeguaris Thomson (Hym. Pteromalidae), Glyphomerus stigma Fabr. (Hym. Torymidae) and Eupelmus urozonus Dalman (Hym. Eupelmidae). P. brandtii is parasitized by G.stigma, Caenacis inflexa Ratzeburg (Hym. Pteromalidae) and Eurytoma rosae Nees (Hym. Eurytomidae). The European dog roses (Rosa species, sect. Caninae (DC.) Ser.), a hybrid complex of allopolyploids, are polymorphic in phenotypic characters (Wissemann, 2000, Wissemann \& Ritz, 2005). The three rose species of our study are widely distributed and abundant in central Europe and they often occur in the same habitats. Although closely related, the selected species of dog roses differ considerably in phenotype. Rosa canina L. is a glabrous rose, R. corymbifera Borkh., a hairy, tomentose rose and $R$. rubiginosa L. a rose with glandular trichomes on the lower leaf surface. At last the level of different gall sizes and the density of the parasitoid's hosts can interact with the coexistence of the gall communities (Hassell, 1978, Weis, 1983, Weis et al., 1985).

In this paper we analyse the multitrophic interactions in D. rosae galls on three different levels and asked the following three questions: 
1. How does the host plant species affect gall growth and parasitism?

2. Have gall characteristics an effect on the structure of the parasitoid community?

3. Do the multitrophic plant-gall-parasitoid interactions change with the geographic location?

\section{Methods}

We sampled galls of $D$. rosae on the three host plants at eight sites along a transect from Southern to Northern Germany in October 2003 (Fig. 1) to study distribution and abundance of the gall-inhabiting parasitoids. At all sites the three host plant species occurred within the same habitat. For each rose species we sampled all galls we can find within each sample site. Longitude, latitude and altitude of each sample site were recorded using a Global Positioning

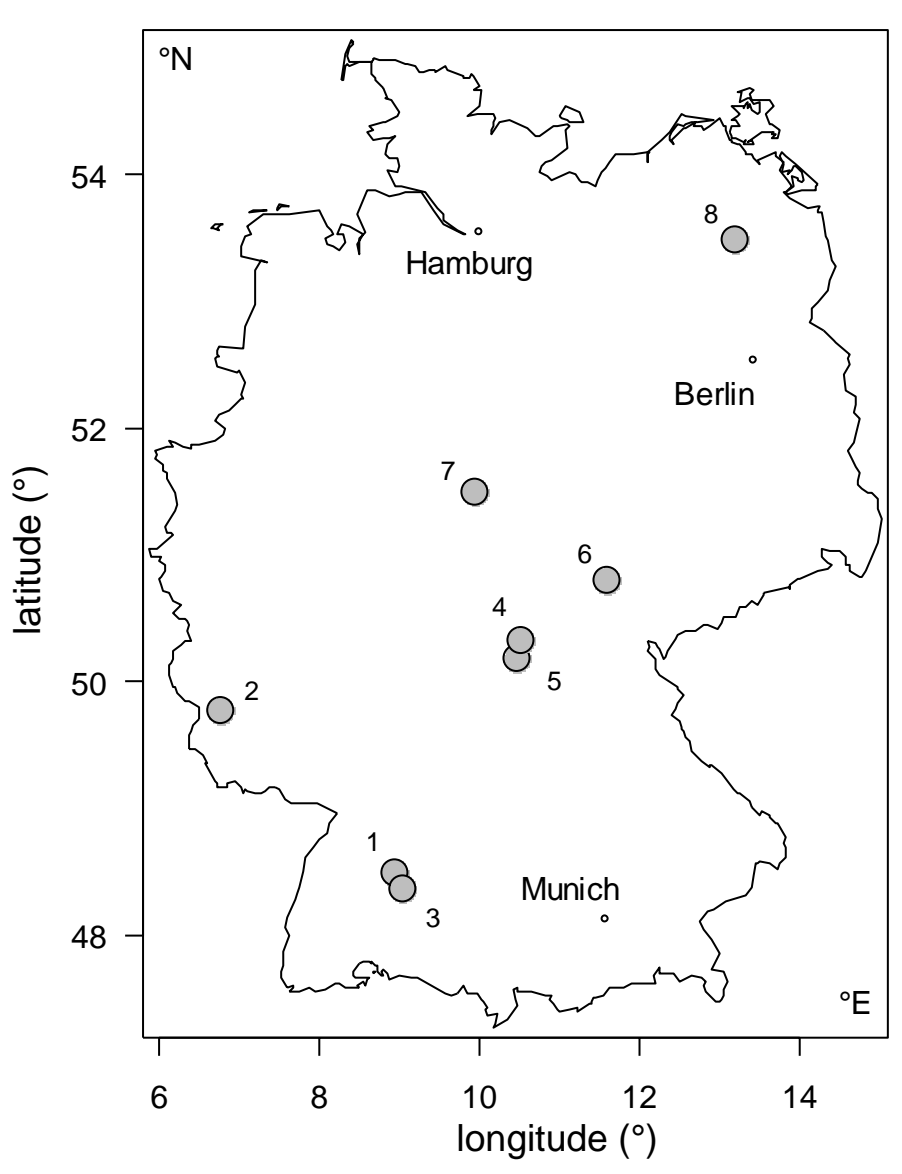

System ("GPS 12 Personal Navigator”, (C) Garmin International Inc.). We performed a principal component analysis on the correlation matrix of latitude, longitude and altitude of each site in order to rank the 8 sites. The scores of the first component (explained variance $84 \%$ ) ranked sites from south to north, from west to east and from high to low altitudes. This order of sample sites within combined geographic distance was given in Fig. 1 and used in further analysis.

Fig. 1. Geographical location of sample sites across Germany. We also plot location of three cities.

The galls were kept individually in plastic pots outside from October to July. In spring 2004 the emerging insects were preserved in alcohol. Additionally the galls were dissected after the main time of emerging, to include all adults, which did not emerge. The gall inhabitants were identified to species. The number of gall chambers of D. rosae was estimated based on a dissection of the galls. The differentiation between chambers of $D$. rosae and the inquilin $P$. brandtii is possible due to the larger size of D. rosae gall chambers (Redfern \& Askew, 
1992). The size of the galls was estimated by measuring width, height and depth according to the formula for a ball volume (gall volume $=4 / 3 \mathrm{r}^{3} \pi \approx 4 / 3 * 1 / 8 *$ width $*$ height $*$ depth $* \pi$ ). The number of gall chambers per shrub and the gall volume per shrub were significantly correlated ( $R$. rubiginosa: $\mathrm{r}^{2}=0.33, \mathrm{p}<0.01, \mathrm{n}=26$ shrubs; $R$. corymbifera: $\mathrm{r}^{2}=0.27, \mathrm{p}<0.01$, $\mathrm{n}=28$; R. canina: $\mathrm{r}^{2}=0.56, \mathrm{p}<0.001, \mathrm{n}=66$ ). Therefore we only used the gall volume in further analyses.

We calculated two percentages of parasitism:

parasitism $(\mathrm{D}+\mathrm{P})=\mathrm{n}$ parasitoids of D.rosae and P. brandtii*100/n developed individuals per gall;

parasitism $(\mathrm{D})=\mathrm{n}$ parasitoids of $D$. rosae* $100 / \mathrm{n}$ developed individuals per gall of the $D$. rosae complex.

Both percentages of parasitism showed similar patterns and they were closely correlated $\left(r^{2}=0.80, p<0.001, n=294\right.$ shrubs). Percentage parasitism $(D+P)$ was on average $4 \%$ lower than percentage parasitism (D). Thus in the following, only the results to the percentage parasitism of the gall-maker (D) were presented.

Prior to all statistical analyses, the percentage of T. bedeguaris, $P$. bedeguaris and $P$. brandtii were arcsine-transformed and the number of gall chambers per shrub and the gall volume were log-transformed to reduce heterogeneity of variances and normalize distributions. The main analyses were made with percent D. rosae, P. brandtii, parasitism (D) and the three most frequent parasitoids O.mediator, G. stigma and T. bedeguaris. We tested the percentages of gall inhabitants against two factors, rose species and sample site (general linear model with two factors; sample site random) with type I sum of squares, using the gall volume as covariable. The study sites were considered as a random factor, the F-ratios were calculated using a restricted mixed model (see Minchinton \& Ross, 1999, Quinn \& Keough, 2002). All correlations in this study are based on Pearson moments (linear correlations). For all statistical calculations we used STATISTICA 6.1.

\section{Results}

We sampled 389 galls from 8 sample sites in Germany (Fig. 1). The gall volume was between $0.0003 \mathrm{~cm}^{3}$ and $36.28 \mathrm{~cm}^{3}$ (see Table 1). In total 6181 individuals developed in the sampled galls, the mean was 15.89 individuals per gall. From 90 galls no gall inhabitant developed. For further analyses we used the galls with one or more developed individuals $(n=299)$. On average $23 \%$ Diplolepis rosae, $1 \%$ Periclistus brandtii and $74 \%$ parasitoids of $D$. rosae developed (percentage parasitism). The most abundant parasitoids of D. rosae were 
Orthopelma mediator with a mean percentage of $21 \%$ and Glyphomerus stigma with $19 \%$. Torymus bedeguaris showed a mean of 3\% (all following percentages are back transformed values). The parasitoids of the inquilin Periclistus brandtii (Caenacis inflexa and Eurytomae rosae) made up just 2\%. The remaining parasitoids Pteromalus bedeguaris, Eupelmus urozonus, Torymus rubi and Torymus spp. contributed 7\%. In table 2 we give an overview of the reared gall inhabitants.

Table 1 Characteristics of the sampled Diplolepis rosae galls; with mean \pm standard error, the minimum and maximum and $\mathrm{n}$ galls.

\begin{tabular}{lllll}
\hline & mean \pm se & min. & max. & n galls \\
\hline Gall volume $\left(\mathrm{cm}^{3}\right)$ & $15.89 \pm 1.14$ & 0.00 & 135 & 389 \\
Sum of individuals & $2.50 \pm 0.11$ & 0.00 & 10 & 389 \\
Species number & $3.33 \pm 0.26$ & 0.00026 & 36.28 & 387 \\
Parasitism $(\mathrm{D}+\mathrm{P})$ & $74.41 \pm 1.79$ & 0 & 100 & 294 \\
\hline
\end{tabular}

Table 2 The inhabitants of Diplolepis rosae galls, based on rearings of $n=299$ galls. Numbers of individuals are given for the gall-maker D. rosae, the inquilin Periclistus brandtii and the parasitoids (sum of individuals, mean \pm standard error (back transformed values), the minimum and maximum). Parasitoids of $D$. rosae are marked with a "D" and parasitoids of $P$. brandtii with a "P".

\begin{tabular}{llllllll}
\hline & host & $\begin{array}{l}\text { sum of } \\
\text { individuals }\end{array}$ & mean & -se & +se & minimum & maximum \\
\hline Diplolepis rosae & & 1968 & 2.08 & 1.87 & 2.31 & 0.00 & 130 \\
$\begin{array}{l}\text { Periclistus brandtii } \\
\text { Orthopelma mediator }\end{array}$ & $\mathrm{D}$ & 1111 & 0.54 & 0.45 & 0.62 & 0.00 & 73 \\
Glyphomerus stigma & $\mathrm{D}, \mathrm{P}$ & 751 & 1.36 & 1.22 & 1.50 & 0.00 & 56 \\
Torymus bedeguaris & $\mathrm{D}$ & 562 & 1.14 & 1.03 & 1.26 & 0.00 & 28 \\
$\begin{array}{l}\text { Pteromalus bedeguaris } \\
\text { Caenaxis inflexa }\end{array}$ & $\mathrm{D}$ & 377 & 0.84 & 0.76 & 0.93 & 0.00 & 44 \\
Eurytoma rosae & $\mathrm{P}$ & 326 & 0.67 & 0.61 & 0.74 & 0.00 & 24 \\
Eupelmus urozonus & $\mathrm{P}$ & 131 & 0.28 & 0.23 & 0.33 & 0.00 & 38 \\
Torymus rubi & $\mathrm{D}, \mathrm{P}$ & 105 & 0.24 & 0.20 & 0.27 & 0.00 & 9 \\
Torymus spp. & $\mathrm{D}$ & 32 & 0.18 & 0.15 & 0.21 & 0.00 & 20 \\
\hline
\end{tabular}

Reared D. rosae individuals (\%) were highest on $R$. rubiginosa (Fig. 2a). We found a significant difference in the percentage between sites and rose species, while the interaction between these two factors was not significant (Table 3). Hence, D. rosae showed on each site a similar distribution among the three rose species. The percent parasitism was higher on the two rose species $R$. corymbifera $(83 \%)$ and $R$. canina (81\%) than on R. rubiginosa $(64 \%)$ 
(Fig. $2 \mathrm{~b}+\mathrm{c}$ ). The percent parasitism was significantly different between sites and rose species. The interaction between site and host was also not significant (Table 3). The percent of inquilines (P. brandtii) and the G. stigma parasitism was highest on R. canina and R. corymbifera. P. brandtii and G. stigma showed significant differences in percentage between sites and rose species, G. stigma with a significant interaction (Table 3). T. bedeguaris and O. mediator were not affected by the rose species, while O. mediator was affected by site with a significant interaction between site and host plant (Table 3). T. bedeguaris showed a significant interaction between the factors site and host species, and the percent was rather high on $R$. corymbifera at one site with even $100 \%$. The gall volume was not related to rose species, but differed between sites (Table 3 ).

Table 3 Effect of rose species (Rosa rubiginosa, R. corymbifera and R. canina) and geographical location of sample sites on the gall volume per gall $(n=296)$, and the gall inhabitants with the percentage of Diplolepis rosae, parasitism, Orthopelma mediator, Torymus bedeguaris, Glyphomerus stigma and Periclistus brandtii per gall $(\mathrm{n}=297)$. For the values of the percentage of the gall inhabitants we accounted for differences in gall characteristics with the gall volume. $\mathrm{SS}=$ sum of square, $\mathrm{df}=$ degrees of freedom; the F-ratio was calculated with the appropriate error term; * $P<0.05$, ** $P<0.01$, *** $P<0.001$.

\begin{tabular}{|c|c|c|c|c|c|c|}
\hline & & Gall volume & Site $(\mathrm{S})$ & Host (H) & $\mathrm{S} \times \mathrm{H}$ & Residua \\
\hline \multirow{3}{*}{ Gall volume } & SS & & 22.41 & 2.18 & 11.37 & 160.81 \\
\hline & df & & 7 & 2 & 14 & 273 \\
\hline & $\mathrm{F}$ & & $5.44 * * *$ & 1.35 & 1.38 & \\
\hline \multirow{3}{*}{ D. rosae } & SS & 30190 & 22261 & 19685 & 10679 & 180422 \\
\hline & $\mathrm{df}$ & 1 & 7 & 2 & 14 & 272 \\
\hline & $\mathrm{F}$ & $45.51 * * *$ & $5.44 * * *$ & $12.90 * * *$ & 1.3446 & \\
\hline \multirow{3}{*}{ Parasitism } & $\mathrm{SS}$ & 34460 & 20802 & 19124 & 11300 & 188517 \\
\hline & df & 1 & 7 & 2 & 14 & 272 \\
\hline & $\mathrm{F}$ & $48.81 * * *$ & $4.21 * * *$ & $13.54 * * *$ & 1.14 & \\
\hline \multirow{3}{*}{ O. mediator } & SS & 22.4 & 25349 & 2483 & 25760 & 218679 \\
\hline & $\mathrm{df}$ & 1 & 7 & 2 & 14 & 272 \\
\hline & $\mathrm{F}$ & 0.03 & $4.50 * * *$ & 0.68 & $2.29 *$ & \\
\hline \multirow{3}{*}{ G. stigma } & $\mathrm{SS}$ & 8961 & 29785 & 12384 & 21525 & 177826 \\
\hline & df & 1 & 7 & 2 & 14 & 272 \\
\hline & $\mathrm{F}$ & $13.71 * * *$ & $6.51 * * *$ & $4.03 *$ & $2.35 * *$ & \\
\hline \multirow{3}{*}{ T. bedeguaris } & SS & 1.85 & 0.446 & 0.156 & 3.14 & 13.96 \\
\hline & df & 1 & 7 & 2 & 14 & 272 \\
\hline & $\mathrm{F}$ & $35.96^{* * *}$ & 1.24 & 1.52 & $4.37 * * *$ & \\
\hline \multirow{3}{*}{ P. brandtii } & SS & 0.305 & 1.14 & 0.508 & 0.847 & 15.6 \\
\hline & df & 1 & 7 & 2 & 14 & 272 \\
\hline & $\mathrm{F}$ & $5.33^{*}$ & $2.86 * *$ & $4.20 *$ & 1.06 & \\
\hline
\end{tabular}




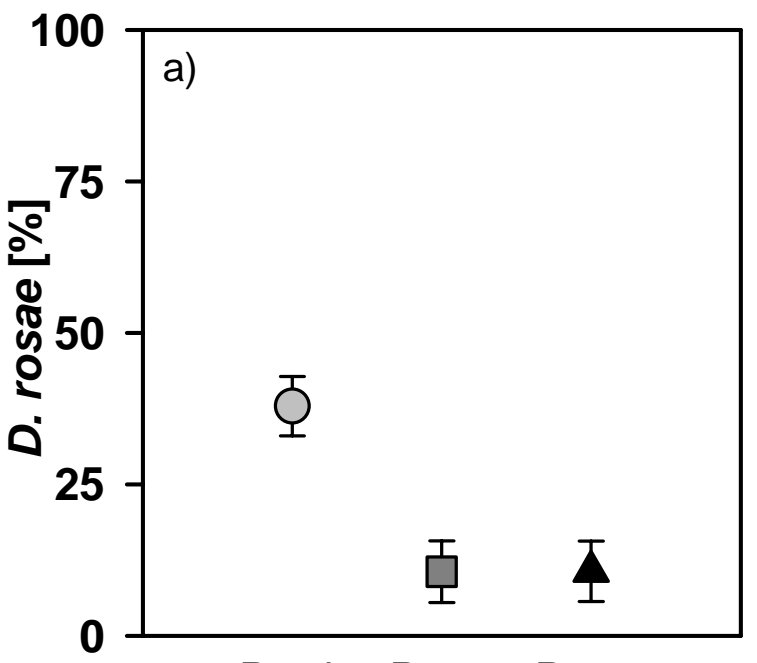

R. rub. R. cor. R. can.

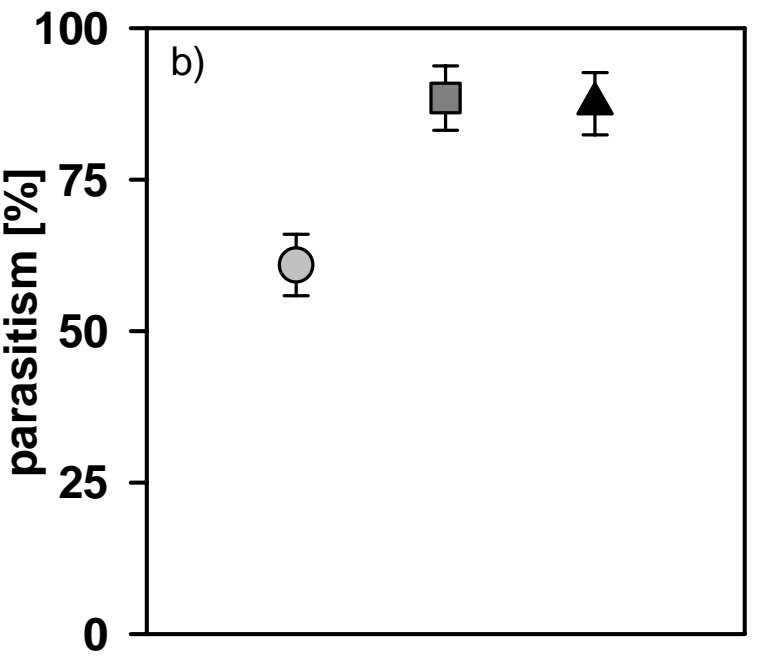

R. rub. R. cor. R. can.

\section{rose species}

Fig. 2. Percent parasitism and survival in a comparison of the three dog rose species (grey circle $=$ Rosa rubiginosa, dark-grey square $=R$. corymbifera, black triangle $=R$. canina) (a) percent surviving Diplolepis rosae and (b) percent parasitism (corrected means were calculated with General Linear Model analyses).

We related the gall volume to the percentage of the inhabitants to examine, whether the gall community was affected by the gall volume. Percent $D$. rosae increased with increasing gall volume (Fig. 3a), whereas percent parasitism decreased (Fig. 3b). This gall size-parasitism relation held for each rose species (R. rubiginosa: $\mathrm{n}=123$ galls, $\mathrm{r}^{2}=0.15, \mathrm{p}<0.001$; R. corymbifera: $\mathrm{n}=73$ galls, $\mathrm{r}^{2}=0.074, \mathrm{p}<0.05 ;$ R. canina: $\left.\mathrm{n}=96 ; \mathrm{r}^{2}=0.31, \mathrm{p}<0.001\right)$. Similarly, we found a significant negative correlation between the percent of G. stigma and the gall volume (Fig. 3c) and a significant positive correlation between the percent of P. brandtii and the gall volume (Fig. 3d). In contrast to percent parasitism, the percent of O. mediator and T. bedeguaris was independent of the gall volume (O. mediator: $\mathrm{r}^{2}=0.00008$, $\mathrm{p}=$ n.s.; T. bedeguaris: $\mathrm{r}^{2}=0.0008, \mathrm{p}=$ n.s.; $\mathrm{n}=297$ galls).

The percent of $D$. rosae increased with increasing longitude and latitude, but decreased with increasing altitude (Fig. 4a-c). In contrast, the percent parasitism decreased with the increasing longitude and latitude, and increased with the increasing altitude (Fig. 4d-f), but for the longitude and the latitude with only marginal significance. G. stigma encourage the patterns over the geographic gradient of the parasitism (longitude: $r^{2}=0.066, p<0.001$; latitude: $\mathrm{r}^{2}=0.069, \mathrm{p}<0.001 ;$ altitude: $\mathrm{r}^{2}=0.080, \mathrm{p}<0.001 ; \mathrm{n}=297$ galls), whereby the correlation between latitude, longitude and altitude and the parasitoids O. mediator, T. bedeguaris and P. brandtii was not significant (for all correlations: $r^{2}<0.0019, p=n$.s., $\mathrm{n}=297$ galls). 


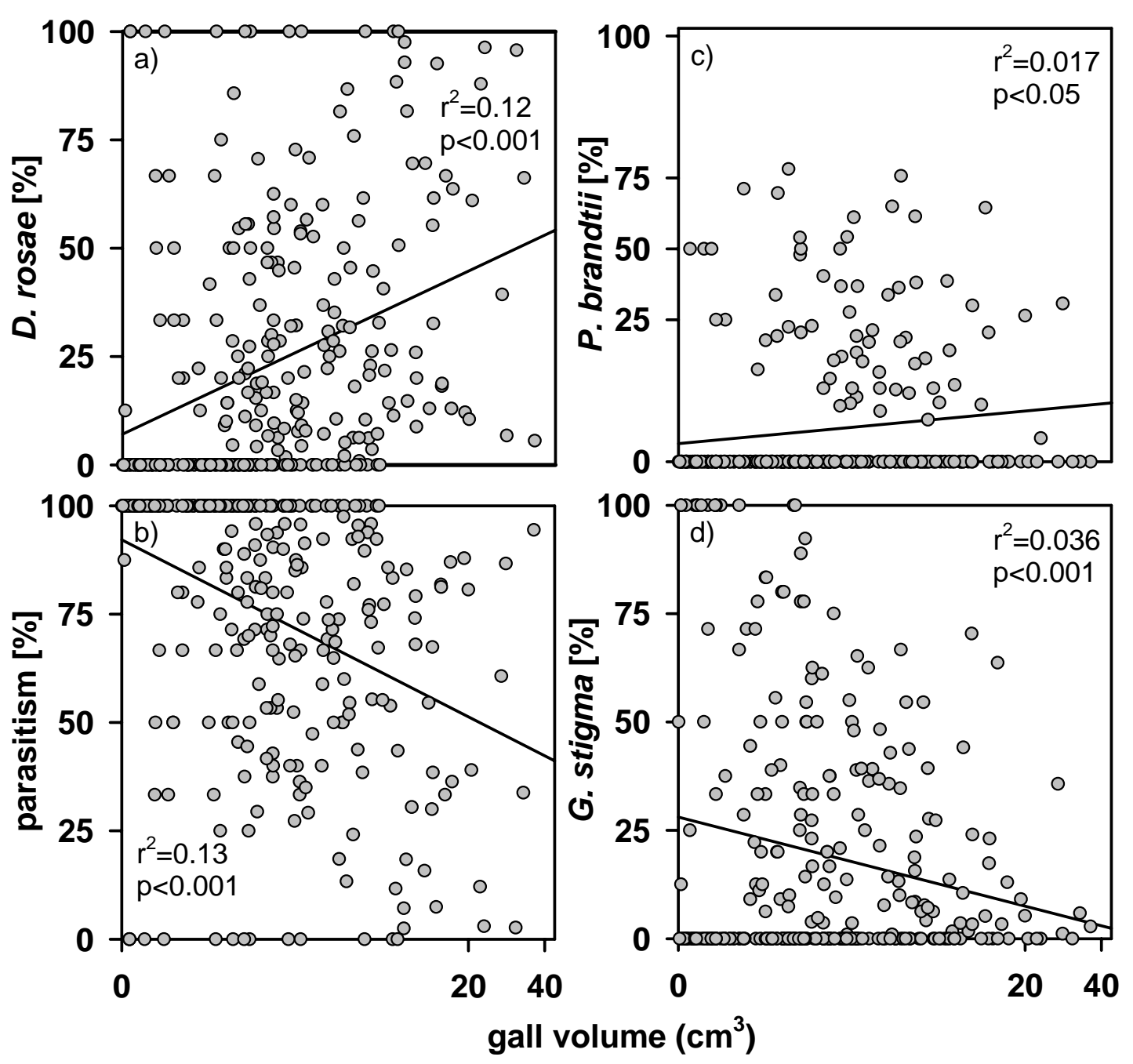

Fig. 3. The gall volume $\left(\mathrm{cm}^{3}\right)$ in relation to the percentage of (a) surviving Diplolepis rosae; (b) total parasitism, (c) reared inquilines, Periclistus brandtii and (d) parasitism by Glyphomerus stigma ( $\mathrm{n}=297$ galls).

\section{Discussion}

In this study we analysed resource-use patterns of a gall-maker and its species rich parasitioid complex on three closely related host plant species on three spatial scales, analyzing the relative role of the host plant species, the gall volume and the geographical position.

The rose species with the highest gall density, $R$. rubiginosa (Klinge et al., submitted), had the highest survival rate of $D$. rosae, while the percent parasitism was lowest. Percent parasitism is often positively related to higher densities of their hosts (i.e. density dependent; Abrahamson \& Weis, 1985). In general, host plant variation can influence higher order interactions within insect communities (Preszler \& Boecklen, 1994, Marquis \& Whelan, 1996, Fritz et al., 1997, Gange, 1995, Eisenbach, 1996). On cattail hybrids, densities of the seed eating lepidopteran, Lymnaecia phragmitella, are lowest but its parasitism highest on hybrids, indicating that the herbivore may preferentially utilise the parent species as hosts to avoid 
their natural enemies (Eisenbach, 1996). In goldenrod (Solidago altissima), the size of galls induced by Eurosta solidaginis is a heritable character of both insect and plant genotype and the gall-makers inhabiting large galls are less susceptible to parasitoids (Weis \& Abrahamson, 1986). Price and Clancy (1986) similarly showed that genetic variation among clones of willow Salix lasiolepis affected size, and the parasitism was inversely related to gall diameter. The gall diameter can differ between the host plant species, thereby affecting multitrophic interactions (Weiss \& Abrahamson, 1985, Price \& Clancy, 1986, Fritz \& Nobel, 1990). However in this study, the gall volume showed no significant differences between the three rose species, but percent parasitism in $R$. rubiginosa was very low. A possible explanation is that host plant traits vary extensively between the three investigated rose species. $R$. rubiginosa has, contrary to the other two rose species, leaf surfaces with glandular trichomes. We also observed that the galls of D. rosae sampled of $R$. rubiginosa plants had the typical odour of $R$. rubiginosa plants even after months of sampling. The glandular trichomes are rich in secondary metabolites belonging to the sesquiterpene group (Klinge, unpublished data). Possibly $R$. rubiginosa is a refuge for the gall-maker due to toxic volatiles negatively affecting the parasitoids. Brown et al. (1995) and Feder (1995) have suggested that enemy escape should facilitate shifts by herbivores to host plants by providing a refuge. For example the beetles of the chrysomelid genus Longitarsus use the secondary compounds of their host plants for anti-predator defence (Dobler, 2001). Plant toxins may be sequestered in the haemolymph or body tissues of resistant herbivores, thus providing them with some degree of protection from their natural enemy complex (Tullberg \& Hunter, 1996, Wink et al., 2000, Muller et al., 2001). Because arthropod herbivores derive their nutrition from host plants, natural enemies using herbivores as prey or hosts will also obtain their nutrition indirectly from plants (Bottrell et al., 1998). Allelochemicals in host or prey diet affects negatively the growth, development, survival and morphology of their predators or parasitoids (Duffey et al., 1986, Gunasena, 1990, Vinson, 1999, Harvey et al., 2003).

The survival of $D$. rosae and the percent parasitism were affected by the gall volume. The percent developed $D$. rosae increased and the percent parasitism decreased with increasing gall volume. The gall diameter frequently affects the percent parasitism of gall forming insects, because the length of the ovipositors limits their ability to oviposit in larger galls (Weis et al., 1985, Price \& Clancy, 1986, Stiling \& Rossi, 1996). Larger gall size has been correlated with increased larval survival and decreased levels of parasitism (Weis et al., 1985, Price \& Clancy, 1986, Stiling \& Rossi, 1996). Stille (1984) reported for D. rosae galls that the degree of parasitism declines with increasing gall size. 

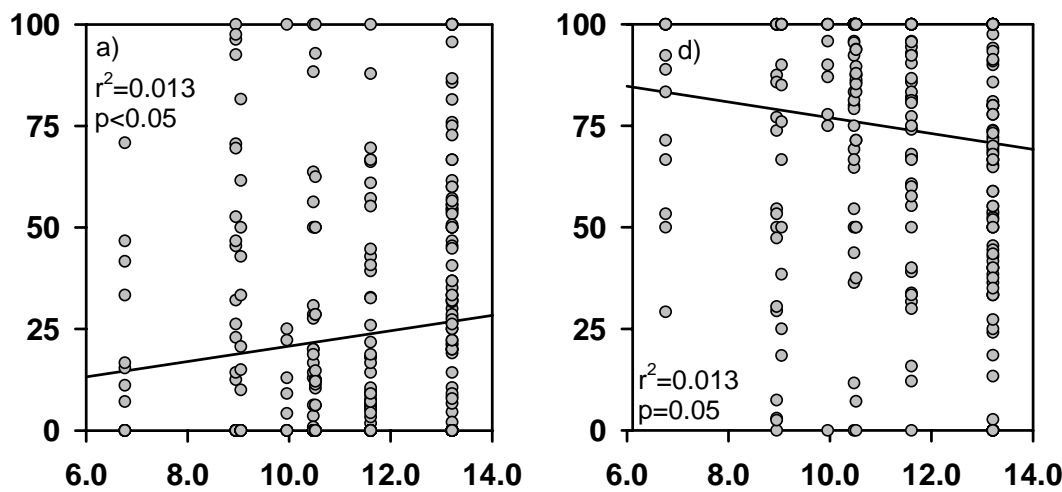

longitude $\left({ }^{\circ}\right)$
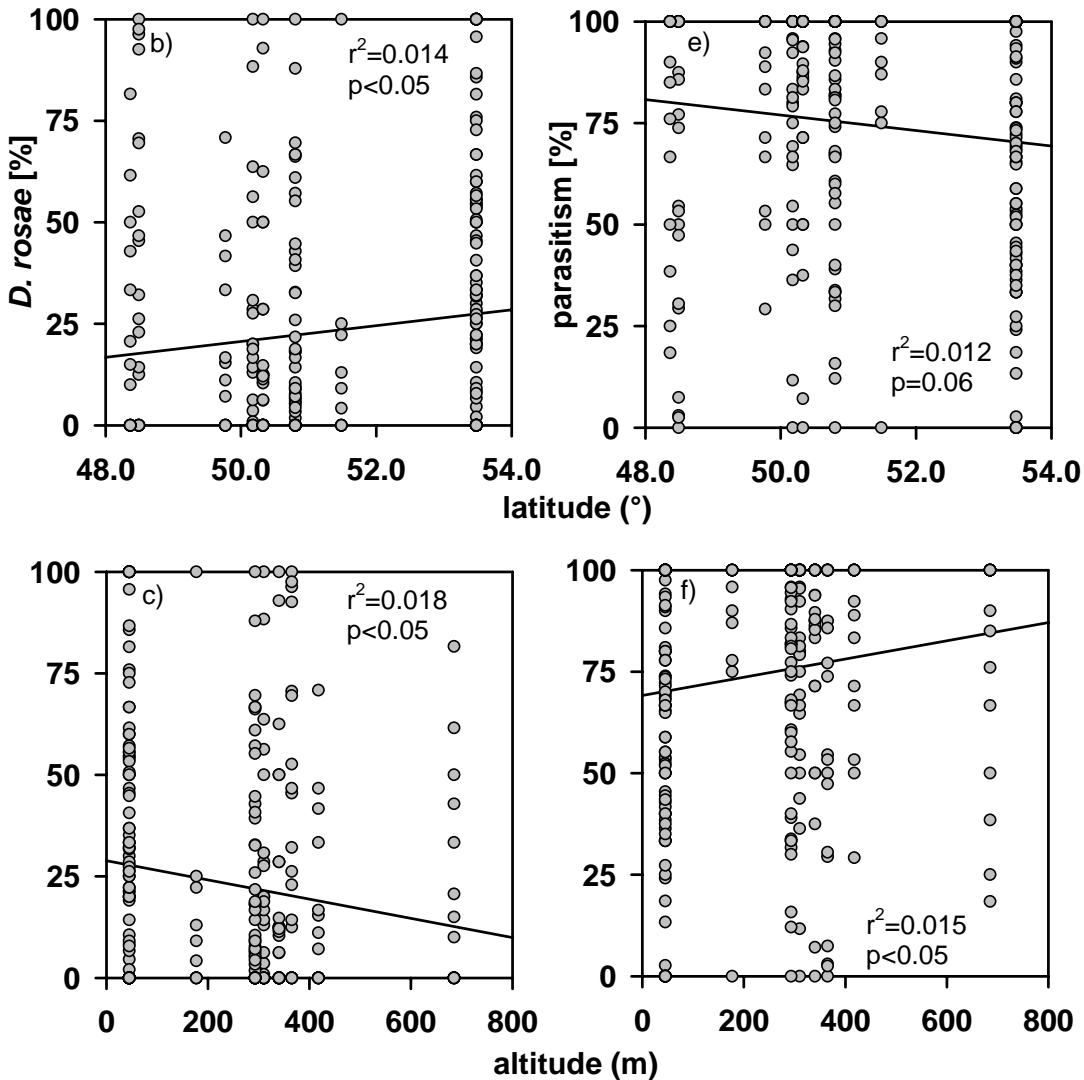

Fig. 5. Geographical parasitism ( $a, d=$ longitude; $b, e=$ latitude; $c, f=$ altitude) in relation to the percentage of surviving Diplolepis rosae (a, b, c), and total parasitism (d, e, f). ( $\mathrm{n}=299$ galls).

We had no significant host species-by-site interactions. These data suggest that environmental variation among sites did not alter the gall community, because the host plant species affected the gall community over the geographic gradient in a consistent way. The relation of host plant species to survived D. rosae individuals and parasitism showed a high consistency. However, there was also a significant trend of a higher D. rosae hatching rate and lower percent parasitism from West to East, from South to North and from high to low altitudes. Such changes in host parasitoid interactions with geography are well known (Holt et al., 1999, Tscharntke et al., 2001, Cattell \& Stiling, 2004, Johnson \& Agrawal, 2005). Parasitoid communities commonly show variation in size and structure from one host population to 
another (Hawkins \& Mills, 1996). Tscharntke et al. (2001) emphasize for Tetramesa-based systems for the need to repeat studies or expand analyses to different geographical locations, since even strong patterns may differ from place to place. Frenzel et al. (2000) showed for U. cardui that the dominant parasitoids are the same at the western and eastern ends of its distributions and the interactions are similar between the parasitoids and the gall-maker.

The rose-gall parasitoids responded in different ways to the gall-maker distribution at the different spatial scales, from the host plant species, the gall volume and to the geographical location. G. stigma was affected by host plant identity, the gall volume and the geographical scale contributing the pattern of percent parasitism, but not the other parasitoid species. O. mediator was affected by site and an interaction between site and host. T. bedeguaris showed a significant interaction between site and host. T. bedeguaris and O. mediator showed no relation to the gall volume. Parasitoids may have very different host-exploitation strategies. Some wasps oviposit before galls are initiated or in an early gall growth stadium, so gall size cannot directly influence such parasitoids (Weis et al., 1992). The inquilin $P$. brandtii showed higher densities on R. corymbifera and R. canina, thereby differing from $D$. rosae with its preference for R. rubiginosa. Numbers of P. brandtii increased with increasing gall volume, as $P$. brandtii induce its own larval chambers in peripheral gall tissues (Askew, 1984).

In conclusion, percent $D$. rosae was highest on $R$. rubiginosa, while percent parasitism was lowest. A reason for this inverse density dependence of parasitism, when comparing three host plant species, may be that $R$. rubiginosa is a refuge for the gall-maker due to toxic volatiles negatively affecting parasitoids. Further an increasing gall volume decreased the percent parasitism, but the gall volume was independent of the host plant species. Thereby we can exclude that the differences in the gall community between rose species were due to differences in gall volumes. The importance of the host plant species did not change with the geographical position, so the influence of plant species on parasitism showed a high geographical consistency. Parasitoid species showed species-specific differences in host use, thereby contributing to the coexistence of this species-rich parasitoid community.

Acknowledgements We are grateful to Roman Fricke, Andrea Vaupel and Melanie Klose for help during the data sampling, Sabrina Brückmann and Brigitte Hornemann for sorting the emerged gall species and opening the galls. Financial support came from the German Science Foundation (Deutsche Forschungsgemeinschaft). 


\section{References}

Askew, R.R. (1984) The biology of gall wasps. Biology of gall insects (ed. By T. N. Ananthakrishnan), pp. 223-271. Oxford \& IBH Publishing, New Dehli.

Blair, K.G. (1945) Notes on the economy of the rose-galls formed by Rhodites (Hymenoptera, Cynipidae). Proceedings of the Royal Entomological Society of London Series A, 20: 26-31.

Bottrell, D.G., Barbosa, P. \& Gould, F. (1998) Manipulating natural enemies by plant variety selection and modification: a realistic strategy? Annual Review of Entomology, 43: 347367.

Brown, M.B., Abrahamson, W.G., Packer, R.A. \& Way, P.A. (1995) The role of naturalenemy escape in a gall-maker host plant shift. Oecologia, 104: 52-60.

Cattell, M.V. \& Stiling, P. (2004) Tritrophic interactions and trade-offs in herbivore fecundity on hybridising host plants. Ecological Entomology, 29: 255-263.

Dobler, S. (2001) Evolutionary aspects of defense by recycled plant compounds in herbivorous insects. Basic and Applied Ecology, 2: 15-26.

Duffey, S.S., Bloem, K.A. \& Campbell, B.C. (1986) Consequences of sequestration of plant natural products in plant-insect-parasitoid interactions. Interactions of plant resistance and parasitoids and predators of insects (ed. By D. J. Boethel and R. D. Eikenbary), pp. 31-60. Horwood, Chichester.

Eisenbach, J. (1996) Three-trophic-level interactions in cattail hybrid-zones. Oecologia, 105: $258-265$.

Feder, J.L. (1995) The effects of parasitoids on sympatric host races of the apple maggot fly, Rhagoletis pomonella (Diptera: Tephritidae). Ecology, 76: 801-813.

Frenzel, M., Eber, S., Klotz, S. \& Brandl, R. (2000) Ecological comparisons across geographical distributions. The thistle gall fly Urophora cardui (Diptera: Tephritidae) on two different Cirsium hosts. Eurasian Journal of Entomology, 97: 183-189.

Fritz, R.S. (1992) Community structure and species interactions of phytophagous insects on resistance and susceptibility host plants. Plant resistance to herbivores and pathogens: ecology, evolution, and genetics (ed. by R. S. Fritz and E. L. Simms), pp. 240-277. University of Chicago Press, Chicago.

Fritz, R.S. (1995) Direct and indirect effects of plant genetic variation in enemy impact. Ecological Entomology, 20: 18-26.

Fritz, R.S., McDonough, S.E. \& Rhoads, A.G. (1997) Effects of plant hybridization on herbivore-parasitoid interactions. Oecologia, 110: 360-367. 
Fritz, R.S. \& Nobel, J. (1990) Host plant variation in mortality of the leaf-folding sawfly on the arroyo willow. Ecological Entomology, 15: 25-35.

Gange, A.C. (1995) Aphid performance in an alder (Alnus) hybrid zone. Ecology, 76: 20742083.

Gunasena, G.H., Vinson, S.B. \& Williams, H.J. (1990) Effects of nicotine on growth, development and survival of the tobacco budworm (Lepidoptera: Noctuidae) and the parasitoid Campoletis sonorensis (Hymenoptera: Ichneumonidae). Journal of Economic Entomology, 83: 1777-1782.

Hare, J.D. (1992) Effects of plant variation on herbivores-natural enemy interactions. Plant resistance to herbivores and pathogens: Ecology, Evolution and Genetics (ed. by R. S. Fritz and E. L. Simms), pp 278-298. University of Chicago Press, Chicago.

Harrison, J.W.H. (1922) The egglaying instincts of Rhodites rosae and certain deductions there from. The Vasculum, 8: 33-37.

Harvey, J.A., Van Dam, N.M. \& Gols, R. (2003) Interactions over four trophic levels: foodplant quality affects development of a hyperparasitoid as mediated through a herbivore and its primary parasitoid. Journal of Animal Ecology, 72: 520-531.

Hassell, M.P. (1978) The Dynamics of Arthropod Predator-Prey Systems. Princeton University Press, Princeton.

Hawkins, B.A. (1994) Pattern and process in host-parasitoid interactions. Cambridge University Press, Cambridge.

Hawkins, B.A. \& Mills N.J. (1996) Variability in parasitoid community structure. Journal of Animal Ecology, 65: 501-516.

Holt, R.D., Lawton, J.H., Polis, G.A. \& Martinez, N.D. (1999) Trophic rank and the speciesarea relationship. Ecology, 80: 1495-1504.

Hunter, M.D. \& Price, P.W. (1992) Playing chutes and ladders: heterogeneity and the relative roles of bottom-up and top-down forces in natural communities. Ecology, 3: 724-732.

Johnson, M.T.J. \& Agrawal, A.A. (2005) Plant genotype and environment interact to shape a diverse arthropod community on Evening Primerose (Oenothera biennis). Ecology, 86: 874-885.

Klinge, K., Tscharntke, T, Wissemann, V \& Brandl, R (submitted) Variability in plantconsumer interactions across host species: Comparing fruit flies, gall wasps and rust fungi on wild roses. Perspectives in Plant Ecology, Evolution and Systematics.

Mani, M.S. (1964) Ecology of plant galls. The Hague, The Netherlands: Dr. W. Junk. 
Marquis, R.J. \& Whelan, C. (1999) Plant morphology, and recruitment of the third trophic level: subtle and little-recognized defenses. Oikos, 75: 330-334.

Minchinton, T.E. \& Ross, P.M. (1999) Oysters as habitats for limpers in a temperate mangrove forest. Australian Journal of Ecology, 24: 157-170.

Moon, D.C. \& Stiling, P. (2000) Relative importance of abiotically-induced direct and indirect effects on a salt marsh herbivore. Ecology, 81: 470-481.

Muller, C., Agerbirk, N., Olsen, C.E., Boeve, J.-L., Schaffner, U. \& Brakefield, P.M. (2001) Sequestration of host plant glucosinolates in the defensive haemolymph of the sawfly Athalia rosae. Journal of Chemical Ecology, 27: 2505-2516.

Preszler, R.W. \& Boecklen, W.J. (1994): A three-trophic-level analysis of the effects of plant hybridization on a leaf-mining moth. Oecologia, 100: 66-73.

Price, P.W. (1987) The role of natural enemies in insect populations. Insect outbreaks (ed. by P. Barbosa and J. C. Schultz), pp. 287-313. Academic Press, San Diego.

Price, P.W. \& Clancy, K.M. (1986) Multiple effects of precipitation on Salix lasiolepis and populations of the stem-galling sawfly, Euura lasiolepis. Ecological Restoration, 1: 114.

Quinn, G.P. \& Keough, M.J. (2002) Experimental design and data analysis for biologists. Cambridge University Press, Cambridge.

Redfern, M. \& Askew, R.R. (1992) Plant galls. The Richmond Publishing Co. Ltd., Slough.

Schröder, D. (1967) Diplolepis (=Rhodites) rosae (L.) (Hym.: Cynipidae) and a review of its parasite complex in Europe. Technical Bulletin. Commonwealth Institute of Biological Control, 9: 93-131.

Stiling, P. and Rossi, A. M. (1996) Complex effects of genotype and environment on insect herbivores and their enemies. Ecology, 77: 2212-2218.

Stille, B. (1984) The effect of host plant and parasitoids on the reproductive success of the parthenogenetic gall wasp Diplolepis rosae (Hymenoptera, Cynipidae). Oecologia, 63: 364-369.

Tscharntke, T, (1994) Tritrophic interactions in gallmaker communities on Phragmites australis: testing ecological hypotheses. The ecology and evolution of gall-forming insects (ed. by P. W. Price, W. J. Mattson and Y. N. Baranchikov), pp. 73-92. USDA Forest Service, North Central Forest Experiment Station, St. Paul, MN, General Technical Report NC-174.

Tscharntke, T., Vidal, S. \& Hawkins, B.A. (2001) Parasitoids of grass-feeding chalcid wasps: a comparison of German and British communities. Oecologia, 129: 445-451. 
Tullberg, B.S. \& Hunter, A.F. (1996) Evolution of larval gregariousness in relation to repellent defences and warning coloration in tree-feeding Macrolepidoptera: a phylogenetic analysis based on independent contrast. Biological Journal of the Linnean Society, 57: 253-276.

Vinson, S.B. (1999) Parasitoid manipulation as a plant defense strategy. Annals of the Entomological Society of America, 92: 812-828.

Weis, A.E. (1983) Patterns of parasitism by Torymus capite on hosts distributed in small patches. Journal of Animal Ecology, 52: 867-877.

Weis, A.E. \& Abrahamson, W.G. (1985) Potential selective pressures by parasitoids on a plant-herbivore interaction. Ecology, 66: 1261-1269.

Weis, A.E. \& Abrahamson, W.G. (1986) Evolution of host-plant manipulation by gall makers: ecological and genetic factors in the Solidago-Eurosta system. The American Naturalist, 127: 681-695.

Weis, A.E., Abrahamson, W.G. \& McCrea, K.D. (1985) Host gall size and oviposition success by the parasitoid Eurytoma gigantean. Ecological Entomology, 10: 341-348.

Weis, A.E., Abrahamson, W.G. \& Andersen, M.C. (1992) Variable selection on Eurosta's gall size. I: The extent and nature of variation in phenotypic selection. Evolution 46: 1674-1697.

Wink, M., Grimm, C., Koschmieder, C., Sporer, F. \& Bergeot, O. (2000) Sequestration of phorbolesters by the aposematically coloured bug Pachycoris klugii (Heteroptera: Scutelleridae) feeding on Jatropha curcas (Euphorbiaceae). Chemoecology, 10: 179184.

Wissemann, V., 2000. Epicuticular wax morphology and the taxonomy of Rosa (section Caninae, subsection Rubiginosae). Plant Systematics and Evolution, 221: 107-112.

Wissemann, V. \& Ritz, C.M. (2005) The genus Rosa (Rosoideae, Rosaceae) revisited: molecular analysis of nrITS-1 and atpB-rbcL intergenic spacer (IGS) versus conventional taxonomy. Botanical Journal of the Linnean Society, 147: 275-290. 


\title{
5 Invertebrate communities on three dog roses are not affected by leaf trichome traits of hosts
}

\begin{abstract}
Trichomes are supposed to influence patterns of abundance and composition in associated invertebrate communities. Dog roses (genus Rosa, section Caninae) are a complex of allopolyploid plant species and species differ in the type of trichomes on their lower leaf surface. We sampled the invertebrate communities on three dog rose species which differ in density and type of trichomes (glandular trichomes - Rosa rubiginosa, tomentose R. corymbifera or glabrous - R. canina) on 18 sites across Germany. At each site, the three selected rose species occurred together. We tested the hypothesis that the differences in the number and morphology of trichomes translated into consistent differences in the associated invertebrate communities on these dog rose species. Altogether we sampled more than 70,000 invertebrate individuals during May, June and July). Contrary to our hypothesis, we found only minor differences in the abundances of invertebrate taxa (Aphidina, Collembola, Araneae, Hymenoptera and Coleoptera) between the three host species. Ordinations also showed few differences in the composition of the communities. Overall our data do not support the hypothesis that trichomes act against invertebrates and especially against herbivores in dog roses. However, our data are consistent with the alternative hypothesis that trichomes are a defence strategy against rust fungi.
\end{abstract}

\section{Introduction}

Trichomes on leafs are widespread across plant species. They are often considered as a defence against (Juniper and Southwood 1986), but may sometimes also be beneficial for herbivores (Eisner et al. 1998). Trichomes may influence attachment and movement of herbivores (Gorb and Gorb 2002, Medeiros and Moreira 2002), may provide shelter for smaller taxa (Walter 1996, Eisner et al. 1998) but may also trap or kill invertebrates (Van Dam and Hare 1998, Eisner et al. 1998). Furthermore, trichomes influence oviposition behaviour (Haddad and Hicks 2000, Lukas and Brodeur 1999) and may reduce leaf palatability (Haddad and Hicks 2000). Regulation of trichome density can be part of induced plant defence (e.g. Zvereva et al. 1998, Agrawal 1999). Consequently, the density and structure of trichomes is supposed to influence host choice of herbivores as well as of other invertebrates (Yencho and Tingey 1994, Zvereva et al. 1998, Ranger and Hower 2002). 
Therefore trichomes are expected to influence the composition of invertebrate communities on host plants (Andres and Connor 2003).

European dog roses (Rosa sect. Caninae (DC.) Ser.) are characterised by their unique system of meiosis ("canina-meiosis"; Wissemann 2000a), which is supposed to be one of the main reasons for the rapid radiation of dog roses since the last glacial epoch (Ritz et al. 2005, Wissemann 2005). Several allopolyploid species originated from multiple hybridisation events, and hybridisation is still common (Ritz et al. 2005, Wissemann 2005). Dog roses are polymorphic in the density and type of trichomes on their lower leaf surface. The leaves of different species may be covered with glandular or both glandular and eglandular trichomes, while those of other species may be tomentose or glabrous (Wissemann 2003). Trichome density may vary within and between species (Wissemann 2000b). Most traits in dog roses including the type of trichomes are inherited matroclinal (Wissemann 2000b). In most plant species, trichome morphology has a genetic basis but density of trichomes is also influenced by environmental factors (e.g. Wilkens et al. 1996, Agrawal 1999). Trichome morphology seems to be inherited by only few genes (e.g. Nielsen et al. 1982, van Dam et al. 1999, Kärkkäinen and Ágren 2002). Traits inherited by few genes which furthermore influence the interaction with associated organisms may eventually lead to different trajectories in the evolution of the associated communities (Whitham et al. 2003), an idea dubbed "extended phenotype" (Dawkins 1982).

We examined invertebrate communities on three dog rose species, which differ in lower leaf surface hairiness. The lower leaf surface of R. rubiginosa L. is covered with glandular trichomes rich in secondary compounds, which are mainly sesquiterpenes (own unpublished data). The lower leaf surface of $R$ corymbifera Borkh. is tomentose whereas the lower leaf surface of $R$. canina L. is glabrous. These three species are widely distributed and abundant in Central Europe. They often occur in the same habitat. Besides hairiness of the lower leaf surface, they also differ in architecture, e.g. number of leaflets per leaf, and phenology (Timmermann and Müller 1994). Feeding experiments showed significant differences in leaf palatability between these three dog rose species (own unpublished data). We tested the hypothesis that $R$. rubiginosa, $R$. corymbifera and $R$. canina harbour different communities of ectophytic invertebrates.

\section{Material and Methods}

We collected data on abundance of invertebrates across 18 study sites throughout Germany during 2002. On each study site the three rose species occurred together (for further details 
see Klinge et al. submitted; Vaupel et al. submitted; Fig. 1). We haphazardly selected 3 to 5 bushes of each dog rose species on each study site for sampling and marked them individually. In total we sampled 88 bushes of R. rubiginosa, 87 of $R$. corymbifera and 88 of $R$. canina. Each bush was sampled in May, June, and July. In the following, the sampling month is referred to as date. To account for possible phenological differences across regions, we started each sampling series in the south. Each series did not last for longer than two weeks.

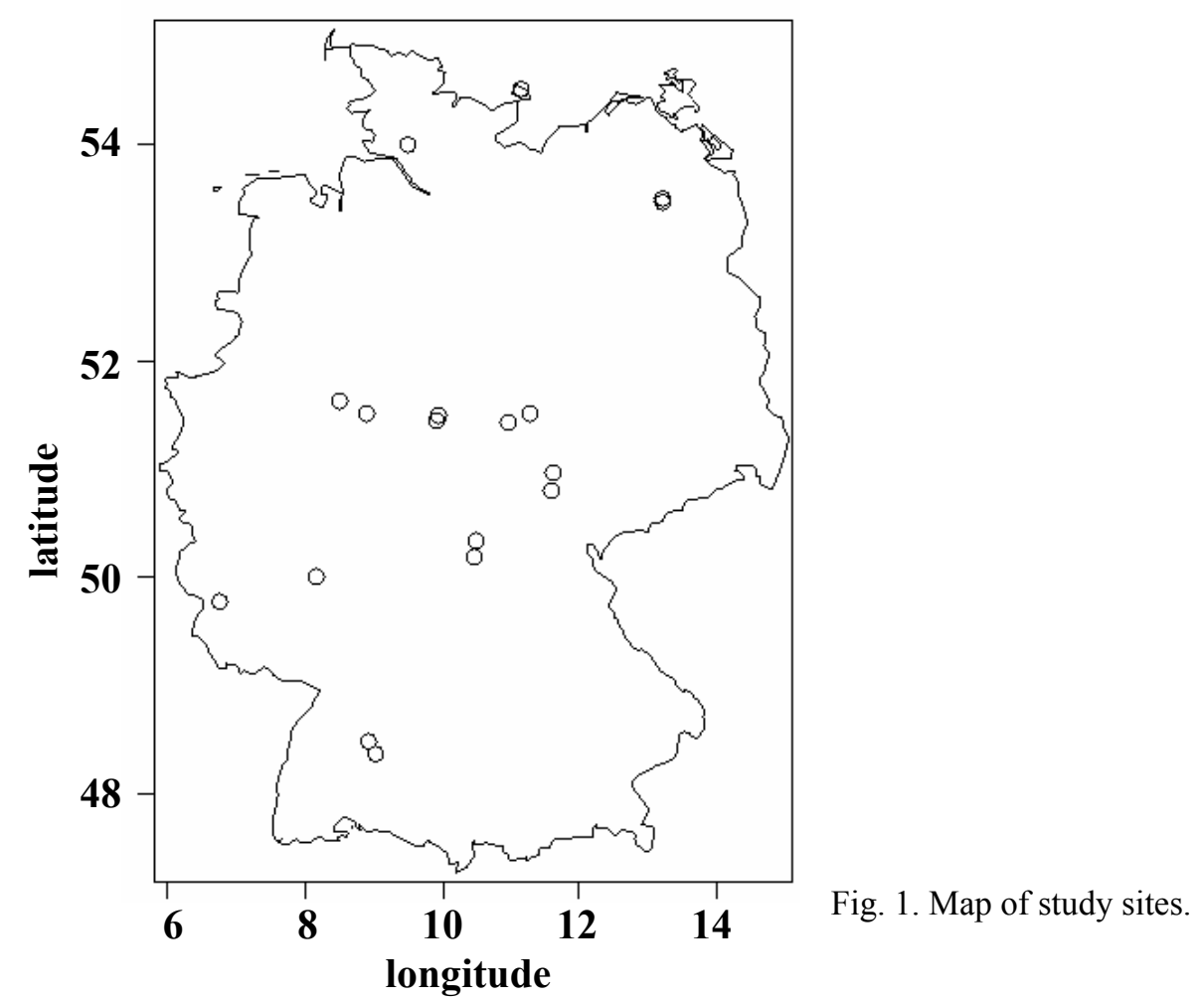

Arthropods were sampled with the beating method (Stechmann et al. 1981). We used a beating tray (circular, diameter $70 \mathrm{~cm}$ ) that was placed below branches $(1-1.5 \mathrm{~m}$ above ground) applying three strokes. This procedure (subsample) was repeated up to five times on different positions of each bush. All subsamples were combined and animals were stored in ethanol. Samples were sorted to major taxonomic groups and some groups were identified to species level. Here we restricted our analyses to the abundances of the major taxonomic groups. From the analyses we excluded obvious tourists (e.g. Trichoptera). Altogether (across all bushes and dates) we sampled 76,667 individuals from 17 taxonomic groups (Table 1). For further analyses we standardised samples (individuals collected per bush and date) by dividing the total number of individuals by the number of subsamples, and standardised samples were $\log _{10}$ transformed after adding 1 to approach normality and homoscedasticity.

We measured seven variables of each bush to characterise its architecture (Table 2). With these data we performed a principal components analysis on the correlation matrix. Two 
components passed the Kaiser criterion. The first component characterised the size of a bush and the second the density of leaves (for further details see Klinge et al. submitted).

Table 1 Basic information for the taxonomic groups of invertebrates sampled from 263 rose bushes during May, June, and July 2002 across 18 sites of Germany (see Fig. 1). Taxa are sorted by their total abundance and we used the first five groups (names in bold) for detailed analyses of the abundances. N: total number of sampled individuals, mean: average abundance across all sampled bushes. Abundance was measured as the number of individuals divided by the subsamples. s.d.: standard deviation. Correlations of the abundances of all taxa (means across dates of standardised transformed samples for each bush, $\mathrm{n}=263$ ) with scores of the first two principle components extracted from variables listed in Table 2. Significant correlations in bold.

\begin{tabular}{|c|c|c|c|c|c|c|c|}
\hline \multirow{2}{*}{ taxon } & \multirow{2}{*}{$\mathrm{N}$} & \multirow{2}{*}{ mean } & \multirow{2}{*}{ s.d. } & \multicolumn{2}{|c|}{ Component 1} & \multicolumn{2}{|c|}{ Component 2} \\
\hline & & & & $\mathrm{r}$ & $\mathrm{p}$ & $\mathrm{r}$ & $\mathrm{p}$ \\
\hline Aphidina & 19.656 & 4.97 & 12.44 & -0.13 & 0.029 & -0.19 & 0.002 \\
\hline Collembola & 19.140 & 4.97 & 8.21 & -0.05 & 0.410 & -0.26 & $<0.001$ \\
\hline Araneae & 11.275 & 2.90 & 3.65 & 0.20 & $<0.001$ & -0.38 & $<0.001$ \\
\hline Hymenoptera & 5.842 & 1.50 & 2.32 & 0.06 & 0.295 & -0.39 & $<0.001$ \\
\hline Coleoptera & 4.444 & 1.13 & 1.70 & 0.21 & $<0.001$ & -0.19 & 0.003 \\
\hline Thysanoptera & 2.969 & 0.74 & 2.00 & -0.06 & 0.351 & -0.40 & $<0.001$ \\
\hline Acari & 2.642 & 0.68 & 1.55 & -0.14 & 0.023 & -0.11 & 0.073 \\
\hline Diptera & 2.481 & 0.63 & 1.01 & 0.11 & 0.069 & -0.27 & $<0.001$ \\
\hline Auchenorrhyncha & 2.259 & 0.59 & 1.81 & 0.06 & 0.338 & 0.00 & 0.958 \\
\hline Heteroptera & 1.806 & 0.48 & 0.85 & 0.10 & 0.111 & -0.29 & $<0.001$ \\
\hline Dermaptera & 1.359 & 0.35 & 0.65 & 0.10 & 0.092 & -0.11 & 0.073 \\
\hline Psocoptera & 1.147 & 0.29 & 0.58 & 0.11 & 0.079 & -0.01 & 0.838 \\
\hline Lepidoptera & 814 & 0.21 & 0.38 & 0.00 & 0.996 & -0.13 & 0.038 \\
\hline Gastropoda & 337 & 0.09 & 0.28 & -0.15 & 0.015 & -0.09 & 0.137 \\
\hline Planipennia & 311 & 0.08 & 0.18 & -0.10 & 0.114 & -0.22 & $<0.001$ \\
\hline Opiliones & 126 & 0.03 & 0.15 & 0.05 & 0.408 & -0.06 & 0.305 \\
\hline Orthoptera & 59 & 0.02 & 0.07 & 0.03 & 0.616 & -0.05 & 0.426 \\
\hline$\Sigma$ & 76.667 & & & & & & \\
\hline
\end{tabular}

As we sampled each bush during three series, our sampling design needs to be analysed by a repeated measurement ANOVA. For each taxonomic group we used type I sums of squares to test for differences in density between dog rose species. Rose species were treated as a fixed factor, whereas site was a random factor. Tests for significance of effects were designed according to Zar (1999). The scores of the first and second principal component were 
introduced as covariables. We did this to account for differences in the architecture of the bushes, which may have influenced abundance patterns. Raw correlations of abundances versus the scores of the first two principal components showed 15 significant correlations (in total 34 correlations), more than expected by chance. Statistical calculations were performed with Statistica v.5.5 (Statsoft Inc., 1999).

Table 2 Variables measured on each bush to characterise plant architecture.

\begin{tabular}{lcll}
\hline variable & transformed & date & comment \\
\hline $\begin{array}{l}\text { bush height }[\mathrm{m}] \\
\text { bush diameter }[\mathrm{m}]\end{array}$ & $\log _{10}$ & June & \\
shoot number & $\log _{10}$ & July & \\
max. shoot diameter [cm] & $\log _{10}$ & July & shoots near ground \\
foliage cover [10\% classes] & $\log _{10}$ & July & shoots near ground \\
number of leaflets per twig & - & June & estimated \\
number of hips per twig & $\log _{10}$ & June & average of 5 twigs $(30 \mathrm{~cm}$ from tip) \\
\hline
\end{tabular}

Furthermore we used redundancy analysis (RDA) to test for differences in the composition of the invertebrate communities between rose species. Rose species were coded into three dummy variables. We included as covariables the variables listed in Table 2 as well as longitude, latitude, and altitude of sampling sites to account for differences in the composition of the insect fauna due to the characteristics both of the bush and the geographic position of the study site. For each date we performed a RDA using Canoco for Windows v. 4.5 (ter Braak and Smilauer 2002). We tested for significant differences between rose species using 999 permutations. Sites were treated as blocks.

\section{Results}

Across all taxonomic units of invertebrates we found more significant correlations between plant architecture and abundances than expected by chance (15 significant correlations; in total 34 correlations; with 5\% significance less than two are expected to be significant by chance). Most of the correlations are with the second component which measures density of the foliage (Table 1). Only five taxonomic groups were sufficiently abundant to allow for single ANOVAs (see Table 1). After accounting for the effects of covariables, all taxonomic groups differed in abundance between sites (Table 3). The factor rose species had no effect (except for Araneae). As expected, abundances of all taxa showed significant differences among dates with a significant interaction between date and site. Furthermore, the interaction 
between date and rose species was significant for most taxonomic groups (except Collembola). Hence, differences in the abundances between rose species changed with dates (Fig. 2). In May, the lowest abundances of most taxonomic groups were found on $R$. rubiginosa, whereas in June and July, respectively, we found the highest abundances on this rose species.

Table 3 Repeated measures ANOVA for five taxonomical groups to test for differences between site (random factor) and rose species (fixed factor; F-tests constructed according to Zar 1999). The first two principal components of the variables presented in Table 2 were introduced as covariables but were not tested.

\begin{tabular}{lrrrrrr}
\hline effect tested & & Aphidina & Collembola & Araneae & Hymenoptera & Coleoptera \\
\hline site & $\mathrm{F}$ & 8.38 & 12.91 & 19.96 & 6.38 & 10.57 \\
species & $\mathrm{p}$ & $<0.001$ & $<0.001$ & $<0.001$ & $<0.001$ & $<0.001$ \\
& $\mathrm{~F}$ & 2.19 & 0.39 & 3.63 & 0.56 & 0.41 \\
site $\mathrm{x}$ species & $\mathrm{p}$ & 0.128 & 0.482 & 0.037 & 0.576 & 0.66 \\
& $\mathrm{~F}$ & 3.07 & 3.13 & 1.71 & 2.17 & 2.33 \\
& $\mathrm{p}$ & $<0.001$ & $<0.001$ & 0.013 & $<0.001$ & $<0.001$ \\
date & $\mathrm{F}$ & 11.28 & 21.51 & 86.58 & 15.00 & 8.16 \\
& $\mathrm{p}$ & $<0.001$ & $<0.001$ & $<0.001$ & $<0.001$ & $<0.001$ \\
date $\mathrm{x}$ site & $\mathrm{F}$ & 8.91 & 12.79 & 6.38 & 7.72 & 5.26 \\
\multirow{2}{*}{ date $\mathrm{x}$ species } & $\mathrm{p}$ & $<0.001$ & $<0.001$ & $<0.001$ & $<0.001$ & $<0.001$ \\
& $\mathrm{~F}$ & 4.61 & 0.31 & 6.82 & 5.43 & 4.36 \\
date $\mathrm{x}$ site $\mathrm{x}$ species & $\mathrm{p}$ & 0.002 & 0.87 & $<0.001$ & $<0.001$ & 0.003 \\
& $\mathrm{~F}$ & 1.94 & 2.30 & 1.20 & 2.21 & 1.97 \\
& $\mathrm{p}$ & $<0.001$ & $<0.001$ & 0.148 & $<0.001$ & $<0.001$ \\
\hline
\end{tabular}

Table 4 Basic information about the RDAs using rose species as predictive variables (Fig. 3). For the first two axes we give eigenvalues, explained variance and significance tests using a Monte Carlo permutation test (999 permutations, sites treated as blocks). All variables listed in Table 2 as well as latitude, longitude, and altitude of sites were entered as covariables.

\begin{tabular}{llll}
\hline date & & axis 1 & axis 2 \\
\hline May & eigenvalue & 0.006 & 0.003 \\
& explained variance[\%] & 0.8 & 0.4 \\
& $\mathrm{p}$ & 0.013 & 0.062 \\
June & eigenvalue & 0.016 & 0.002 \\
& explained variance[\%] & 1.9 & 0.2 \\
& $\mathrm{p}$ & 0.003 & 0.004 \\
July & eigenvalue & 0.033 & 0.002 \\
& explained variance[\%] & 4.4 & 0.3 \\
& $\mathrm{p}$ & 0.001 & 0.001 \\
\hline
\end{tabular}


The results of the RDAs differed somewhat between dates (Table 4, Fig. 3). In May, only one axis was significant. The eigenvalue of this axis was also very low. Along the first and significant axis no clear differentiation between rose species was evident (Fig. 3 May). Thus, there were no differences in the taxonomic composition of invertebrate communities between rose species in May. In June and July, two axes were significant, and overall the scores of the samples for each rose species are clearly separated (Fig. 3, June and July). Explained variance, however, was again very low (June: $2.1 \%$, July: $4.7 \%$ ).

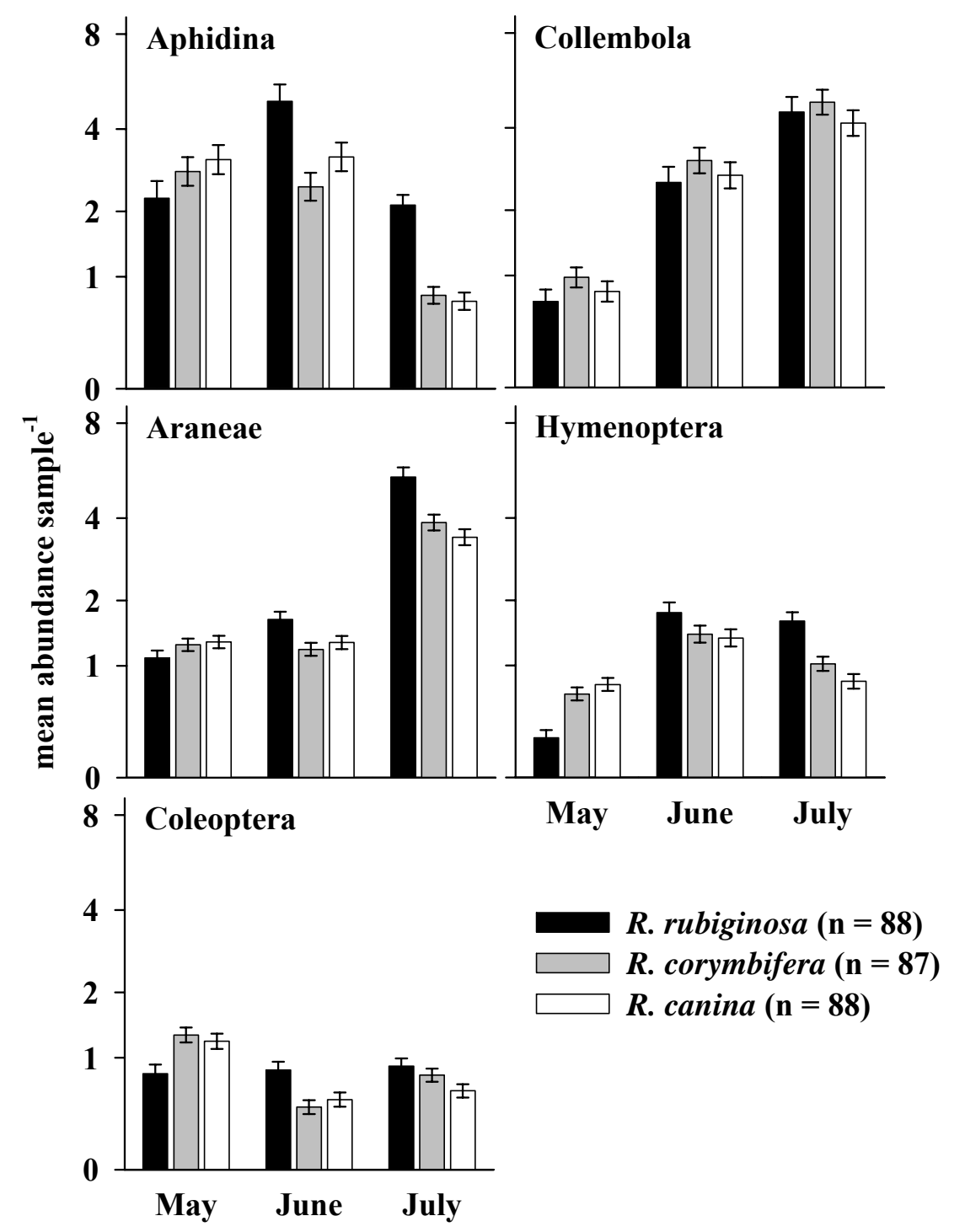

Fig. 2. Means of the abundance of five taxonomic groups on three dog rose species for the three sampling dates. Note the log-scale of the ordinate.

\section{Discussion}

When we started our project, we expected a clear increase in the abundance of invertebrate taxa from R. rubiginosa (glandular) to R. canina (glabrous). Particularly for herbivores we expected lower abundances on $R$. rubiginosa compared to the other two rose species. Contrary 
to the expectation, however, we did not find clear differences between the three rose species. Nevertheless, the phenological patterns of abundances differed across the three investigated rose species. In May, abundances of invertebrates on $R$. rubiginosa were lower than on the other two species, a pattern which changed in June and July. However, the difference between rose species was only pronounced in aphids, with about $36 \%$ more aphids attacking the glandular R. rubiginosa in June and July. For R. corymbifera and R. canina we never found significant differences across all dates and arthropod groups. Overall our data show clearly that trichomes did not act as an effective defence against herbivorous invertebrates. Similar results were found on Arctostaphylos by Andres and Connor (2003).

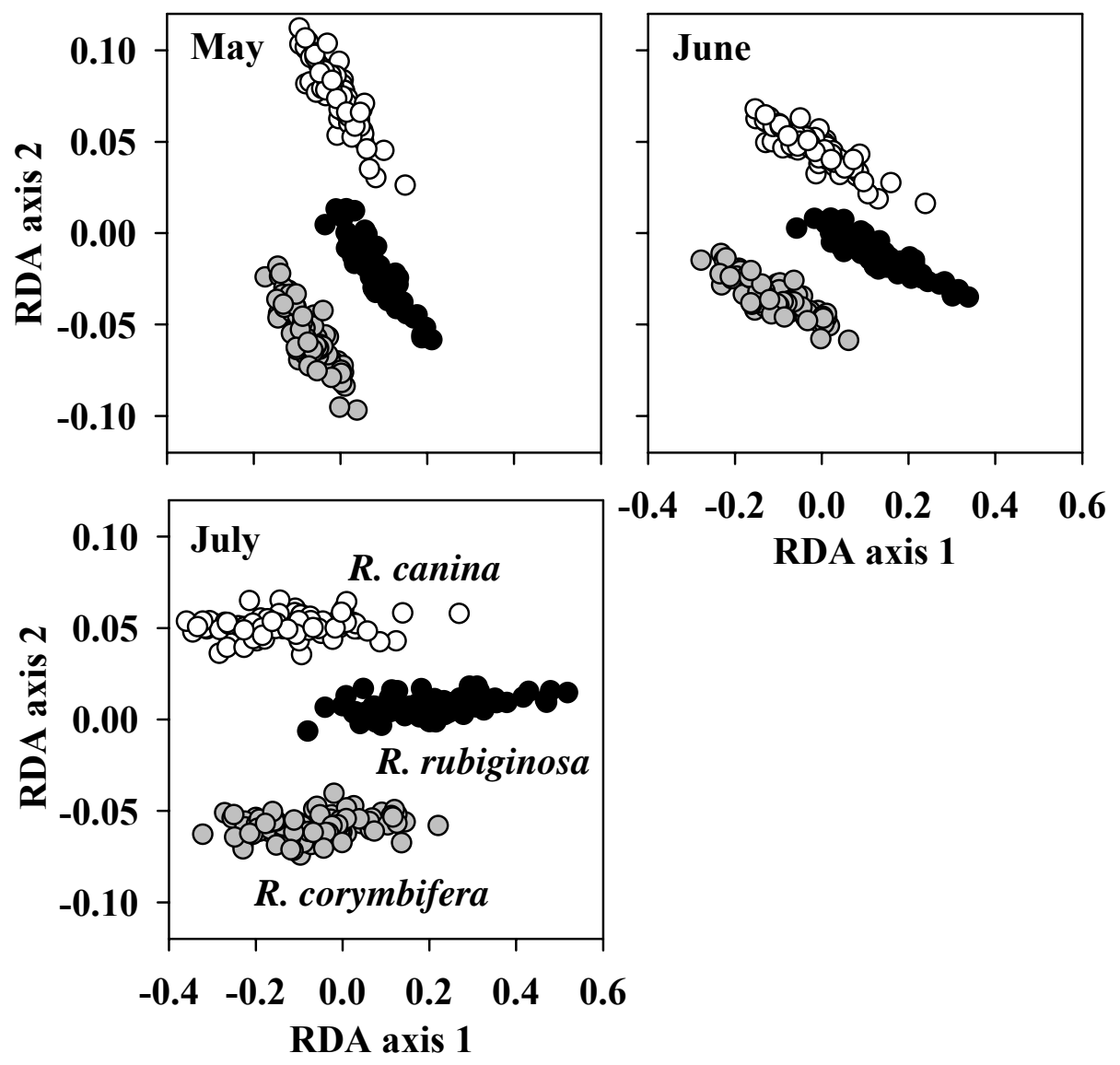

Fig. 3. Plot of sample scores of RDA for each sampling date in 2002. Each symbol represents one sampled bush. Proportions of explained variance for each axis are given in parentheses.

We want to list several arguments which may explain our finding that trichomes have little influence on the abundance of arthropods across dog roses. Firstly, the negative effect of trichomes on invertebrate abundance is positively correlated with trichome length and negatively with trichome density (Andres and Connor 2003). Trichomes on the lower leaf surface of $R$. corymbifera are both short and dense. Hence, these trichomes may be not very effective against insects. Secondly, glandular trichomes of $R$. rubiginosa may serve other 
purposes than defence against herbivores in the first place. Valkama et al. (2005) pointed out that glandular trichomes may have evolved as a strategy against rust fungi. One may speculate that trichomes on the lower leaf surface impede the germination tubes of fungi to enter the plant via the stomata, as proposed by Bahçecioğlu and Yildiz (2005). This would explain why trichomes occur only on the lower leaf surface. Furthermore, sesquiterpenes, which occur in the trichomes of R. rubiginosa, are known to inhibit the growth of fungi (e.g. AlvarezCastellanos et al. 2001, Cakir et al. 2004). We found lower densities of the rust fungi Phragmidium on $R$. rubiginosa (Klinge et al. 2005, submitted, Ritz et al. 2005) than on $R$. canina and $R$. corymbifera, which is consistent with the idea of Valkama et al. (2005). Thirdly, the difference between rose species during the year may be due to phenological differences in the physiology of the three rose species.

Nevertheless, if trichomes evolved as a defence against fungi, they may affect invertebrates on the host indirectly, especially herbivores. Kluth et al. (2001) showed for Cirsium arvense that abundance of some ectophagous herbivores differed between non-infected and infected shoots. Particularly aphids showed a higher density on infected shoots. In our study we found the opposite trend with more aphids in both June and July on the less infected rose species. Furthermore, in a correlation across all sampled bushes we found a negative correlation between the abundance of aphids in July and the number of Phragmidium sporangia per leaflet (own unpublished data, both $\log _{10}$-transformed after adding $1, r=-0.22, p<0.001$ ). This negative correlation is due to differences in the attack rate of Phragmidium between rose species. Fungi are known to induce changes similar to those during senescence (Barbosa 1991). Thereby concentrations of free amino acids increase (Gildow 1983), which are of particular importance for phloem feeders (Bernays and Chapman 1994). Our data do not support this idea, and we believe that the differences in the abundance of aphids between dog roses may be due to differences in the phenology.

Trichomes may not only affect density but also community composition of invertebrates. Although we found clear significant differences in the composition between rose species in June and July, the amount of variation explained by the rose species is dauntingly low. One may argue that plots of the sample scores show a clear separation between host species (Fig. 3). However, note that the presented ordination is optimised for differences between rose species. Again our data suggest that trichomes had little effect on the arthropods. Hence, our results do not support the idea of the extended phenotype. Several authors have shown that the subtle genetic differences between trees induce differences in the composition of herbivores living on these trees (e.g. Whitham et al. 2003). At present we explain the obvious failure of 
our study to demonstrate extended phenotypes with respect to trichomes with the idea that trichomes were not evolved as a defence against invertebrates.

Overall our data show that the general composition of the invertebrate fauna is fairly similar across the three studied rose species. Apparently, trichomes had little effect on associated communities. Hence the fascinating diversity of roses had only limited impact on distribution and abundance of the food webs associated with these plants.

Acknowledgements We thank Daniel Groß for linguistic advice, Christiane Ritz for help during field work and Anne Kempel and Svenja Hampl for sorting many of the samples. The work was supported by the Deutsche Forschungsgemeinschaft (DFG) within the Priority Programme SPP 1127 (Adaptive Radiation - Origin of Biological Diversity).

\section{References}

Achtziger, R. 1995. Die Struktur von Insektengemeinschaften an Gehölzen: Die HemipterenFauna als Beispiel für die Biodiversität von Hecken- und Waldrandökosystemen. Bayreuther Institut für Terrestrische Ökosystemforschung (BITÖK), Bayreuth.

Agrawal, A. A. 1999. Induced responses to herbivory in wild radish: Effects on several herbivores and plant fitness. - Ecology 80: 1713-1723.

Alvarez-Castellanos, P. P., Bishop, C. D. and Pasqual-Villalobos, M. J. 2001. Antifungal activity of the essential oil of flowerheads of garland chrysanthemum (Chrysanthemum coronarium) against agricultural pathogens. - Phytochemistry 57: 99-102.

Andres, M. A. and Connor, E. F. 2003. The community-wide and guild specific effects of pubescence on the folivorous insects of manzanitas Arctostaphylos spp. - Ecol. Entomol. 28: 383-396.

Bahçecioğlu, Z. and Yildiz, B. 2005. A study on the microfungi of Sivas Province. - Turk. J. Bot. 29: 23-44.

Barbosa, P. 1991. Plant pathogens and nonvector herbivores. - In: Barbosa, P. (ed.), Microbial Mediation of Plant-Herbivore Interactions. John Wiley \& Sons, pp. 341-382.

Bernays, E. A. and Chapman, R. F. 1994. Host-Plant Selection by Phytophagous Insects. Chapman \& Hall, New York, London.

Cakir, A., Kordali, S., Zengin, H., Izumi, S. and Hirata, T. 2004. Composition and antifungal activity of essential oils isolated from Hypericum hyssopifolium and Hypericum heterophyllum. - Flavour Fragr. J. 19: 62-68. 
Dalin, P., Björkman, C. and Eklund, K. 2004. Leaf beetle grazing does not induce willow trichome defence in the coppicing willow Salix viminalis. - Agr. Forest Entomol. 6: 105-109.

Dawkins, R. 1982. The Extended Phenotype. - Oxford Univ. Press.

Eisner, T., Eisner, M. and Hoebeke, E. R. 1998. When defense backfires: Detrimental effect of a plant's protective trichomes on an insect beneficial to the plant. - Proc. Natl. Acad. Sci. USA 95: 4410-4414.

Gildow, F. E. 1983. Influence of barley yellow dwarf virus-infected oats and barley on morphology of aphid vectors. - Phytopathology 73: 1196-1199.

Gorb, E. V. and Gorb, S. N. 2002. Attachment ability of the beetle Chrysolina fastuosa on various plant surfaces. - Ent. Ex. Appl. 105: 13-28.

Haddad, N. M. and Hicks, W. M. 2000. Host pubescence and the behavior and performance of the butterfly Papilio troilus (Lepidoptera: Papilionidae). - Environ. Entomol. 29: 299303.

Juniper, B. E. and Southwood, T.R.E. (eds.) 1986. Insects and the Plant Surface. - Edward Arnold (Publishers) Ltd, London.

Kärkkäinen, K. and Ágren, J. 2002. Genetic basis of trichome production in Arabidopsis lyrata. - Hereditas 136: 219-226.

Klinge, K., Tscharntke, T., Wissemann, V., Brandl, R. (submitted). Variability in plantconsumer interactions across host species: Comparing fruit flies, gall wasps and rust fungi on wild roses. - Perspect. Plant Ecol.

Kluth, S., Kruess, A. and Tscharntke, T. 2001. Interactions between the rust fungus Puccina punctiformis and ectophagous and endophagous insects on creeping thistles. - J. Appl. Ecol. 38: 548-556.

Lukas, É. and Brodeur, J. 1999. Oviposition site selection by the predatory midge Aphidoletes aphidimyza (Diptera: Cecidomyiidae). - Environ. Entomol. 28: 622-627.

Medeiros, L., and Moreira, G. R. P. 2002. Moving on hairy surfaces: modifications of Gratiana spadicea larval legs to attach on its host plant Solanum sisymbriifolium. - Ent. Ex. Appl. 102: 295-305.

Nielsen, M. T., Jones, G. A., and Collings, G. B. 1982. Inheritance pattern for secreting and nonsecreting glandular trichomes in tobacco Nicotiana tabacum. - Crop Science 22: 1051-1053.

Ranger, C. M. and Hower, A. A. 2002. Glandular trichomes on perennial alfalfa affect hostselection behavior of Empoasca fabae. - Ent. Ex. Appl. 105: 71-81. 
Ritz, C. M., Maier, W. F. A., Oberwinkler, F. and Wissemann, V. 2005. Different evolutionary histories of two Phragmidium species infecting the same dog rose hosts. Mycol. Res. 109: 603-609.

Ritz, C.M., Schmuths, H., Wissemann, V. 2005. Evolution by reticulation: European dogroses originated by multiple hybridization across the genus Rosa. - J. Hered. 96:1-11.

Wissemann, V. 2005b. Evolution by reticulation: European dog roses originated by multiple hybridization across the genus Rosa. - J. Hered. 96: 1-11.

StatSoft, Inc. 1999. Statistica for windows. - Kernel ver. 5.5, Tulsa, OK.

Stechmann, D.-H., Bauer, G., Dreyer, W., Heusinger, G. and Zwölfer, H. 1981. Die Erfassung der Entomofauna von Heckenpflanzen (Wildrose, Schlehe, Weißdorn) mit Hilfe der Klopfprobenmethode. - Mitt. Dtsch. Ges. allg. angew. Ent. 3:12-26.

Strong, D. R., Lawton, J. H. and Southwood, T. R. E. 1984. Insects on Plants - Community Patterns and Mechanisms. - Blackwell Scientific Publications LTD.

ter Braak, C. J. F. and Smilauer, P. 2002. Canoco for Windows. - v. 4.5, Biometris - Plant Research International.

Timmermann, G. and Müller, T. 1994. Wildrosen und Weißdorne Mitteleuropas Landschaftsgerechte Sträucher und Bäume. -Verlag des Deutschen Alpenvereins e.V.

Valkama, E., Koricheva, J., Salminen, J.-P., Helander, M., Saloniemi, I. Saikkonen, K. and Pihlaja, K. 2005. Leaf surface traits: overlooked determinants of birch resistance to herbivores and foliar micro-fungi?. - Trees 19: 191-197.

van Dam, N. M., Hare, J. D. 1998. Differences in distribution and performance of two sapsucking herbivores on glandular and non-glandular Datura wrightii. - Ecol. Entomol. 23: $22-32$.

van Dam, N. M., Hare, J. D. and Elle, E. 1999. Inheritance and distribution of trichome phenotypes in Datura wrightii. - J. Hered. 90: 220-227.

Walter, D. E. 1996. Living on leaves: Mites, tomenta, and leaf domatia. - Annu. Rev. Entomol. 41: 101-114.

Whitham, T. G., Young, W. P., Martinsen, G. D., Gehring, C. A., Bailey, J. K., Lindroth, R. L., Woolbright, S. and Kuske, C.R. 2003. Community and ecosystem genetics: a consequence of the extended phenotype. - Ecology 84: 559-573.

Wilkens, R. T., Shea, G. O., Halbreich, S. and Stamp, N. E. 1996. Resource availability and the trichome defenses of tomato plants. Oecologia 106: 181-191. 
Wissemann, V. 2000a. Molekulargenetische und morphologisch-anatomische Untersuchungen zur Evolution und Genomzusammensetzung von Wildrosen der Sektion Caninae. - Bot. Jahrb. Syst. 122: 357- 429.

Wissemann, V. 2000b. Epicuticular wax morphology and the taxonomy of Rosa (section Caninae, subsection Rubiginosae). - Plant Syst. Evol. 221: 107-112.

Wissemann, V. 2003. Male correlated non-matroclinal character inheritance in reciprocal hybrids of Rosa section Caninae (DC). Ser. (Rosaceae). - Plant Syst. Evol. 241: 213221.

Wissemann, V. 2005. Evolution by hybridisation. The influence of reticulate evolution on biosymmetrical patterns and processes in plants. - Theory Bioscienc. 123: 223-233.

Yencho, G. C. and Tingey, W. M. 1994. Glandular trichomes of Solanum berthaultii alter host preference of the colorado potatoe beetle, Leptinotarsa decemlineata. - Ent. Ex. Appl. 70: $217-225$.

Zar, J. H. 1999. Biostatistical Analysis. - Prentice Hall, Eaglewood Cliffs, NJ.

Zvereva, E. L., Kozlov, M. V. and Niemelä, P. 1998. Effects of leaf pubescence in Salix borealis on host-plant choice and feeding behavior of the leaf beetle, Melanosoma lapponica. - Ent. Ex. Appl. 89: 297-303. 


\title{
6 Genetic differentiation between populations of the European rose hip fly Rhagoletis alternata
}

\begin{abstract}
Phytophagous insects may adapt to host plants, thereby forming host races as a first step during sympatric speciation. Here, we tested for genetic differentiation between populations of Rh. alternata Fall. (Diptera: Tephritidae). We collected larvae from three rose species of the section Caninae (Rosa canina L., R corymbifera Borkh., R. rubiginosa L.) from 15 sites across Germany, where the three roses occurred together, and from three sites in Switzerland. Roses differ in morphology (e.g. leaf glands) as well as phenology. We were able to score 9 allozyme loci ( 5 polymorphic). Populations from the three hosts did not differ in genetic variability. Our results provide two unexpected findings. Firstly we found significant genetic differentiation between populations from different host species. However, the differentiation was very low $(0.9 \%)$. Secondly, we found surprisingly little geographic structure of genetic differentiation between populations of this fruit fly across central Europe. We offer three mutually non-exclusive explanations for these findings. Firstly, gene flow between populations of Rh. alternata is high. Secondly, the pattern of genetic differentiation is based on a recent expansion of the distributional range of the fly. Thirdly, the ongoing gene flow between rose species of section Caninae acts as a hybrid bridge.
\end{abstract}

Keywords allozymes, gene flow, host races, isolation by distance, hybridisation

\section{Introduction}

Phytophagous insects complete at least one step of their life cycle on one host plant. During this time an individual has to cover all its nutritional needs. Furthermore the individual must avoid predators and parasitoids (Thompson, 1994). The specific selection regime of a host may lead to an adaptive divergence of populations exploiting different hosts, even if hosts occur sympatrically. Insects may adapt to the mechanical or chemical defence and also to the phenology of a host. Overall this may lead to the formation of host races (biotypes), genetic differentiated and sympatric populations of exploiters that use different species of host plants (Drès \& Mallet, 2002). The formation of host races is an intermediate step during sympatric speciation (Diehl \& Bush, 1984). Tephritids are a group of phytophagous insects well known for the occurrence of host races (McPheron, Smith \& Berlocher, 1988a, 1988b; Itami, Craig \& Horner, 1998; Diegisser et al., 2004). Tephritids mate on the host plant (Zwölfer, 1974) and 
this "rendezvous - behaviour" isolates populations on different host plants. Differences in the selection regime of hosts may then select for adaptive differences between populations. In the famous example of Rhagoletis pomonella, the larvae develop in fruits of Crataegus and Malus. Fruits are produced for the dispersal of seeds by vertebrates. Consequently, fruits are often not protected by toxic substances. Nevertheless, Malus and Crataegus differ in their morphology and phenology, which selects for adaptive differences between populations exploiting the two hosts (Feder et al., 1997).

Larvae of the European rose hip fly Rhagoletis alternata (Diptera: Tephritidae) develop in hips of a number of rose species from several sections. The adults emerge in June. The female flies oviposit eggs under the skin of green hips (only one egg per hip). Subsequently the females mark the hip with a pheromone which deters other females to lay eggs into the same hip (Bauer, 1986, 1998). The larvae feed only on the hypanthium, seeds are not attacked. In October, the mature larvae leave the hip for pupation and hibernation in soil. Roses differ in phenology of flowering and fruit production which may initiate a process similar to the divergence of host races in Rh. pomonella.

The hosts analysed during the present study (R. canina, R. corymbifera, R. rubiginosa) are members of the section Caninae. This section is characterized by an allopolyploid constitution, heterogamous reproduction and maternally skewed meiosis (see; Täckholm, 1920, 1922; Wissemann, 2000, 2002; Ritz \& Wissemann, 2003; Ritz, Schmuths \& Wisseman, 2005; Wissemann \& Ritz, 2005). The three selected species differ in phenology of flowering and several morphological traits that could select for host races ( $R$. canina: leaves and rhachis eglandular, glabrous, R. corymbifera: eglandular, hairy, R. rubiginosa: glandular, hairy). Hips of $R$. rubiginosa ripen one month earlier (August - September) than fruits of $R$. corymbifera and R. canina (September - October).

Here, we test for genetic differentiation between populations of Rh.alternata on R. rubiginosa, R. corymbifera and R. canina across Germany. Consistent and significant genetic differentiation between populations on different host plants within sites would be the first evidence for host race formation in this tephritid. For the evaluation of genetic differentiation we used allozymes. Although compared to microsatellites or AFLPs a crude method, allozymes provide an appropriate methodology for the level of genetic differentiation expected for host races in the genus Rhagoletis and other tephritids (McPheron et al. 1988a, 1988b; Itami et al.,1998; Berlocher, 2000). 


\section{Methods}

Hips of $R$. rubiginosa, $R$. corymbifera and $R$. canina infested by larvae of Rh. alternata were collected in September and October 2003 at 15 sites across Germany (Fig. 1; sample sizes are given in the Appendix). For a broader geographic evaluation of genetic differentiation we also collected infested fruits of several rose species at three valleys of Valais in September and October 2004 (Fig. 1; Appendix). For most of our analysis we treated larvae collected from each rose species within a sampling site as a "population". For the samples from Valais, however, we pooled all larvae of a site.

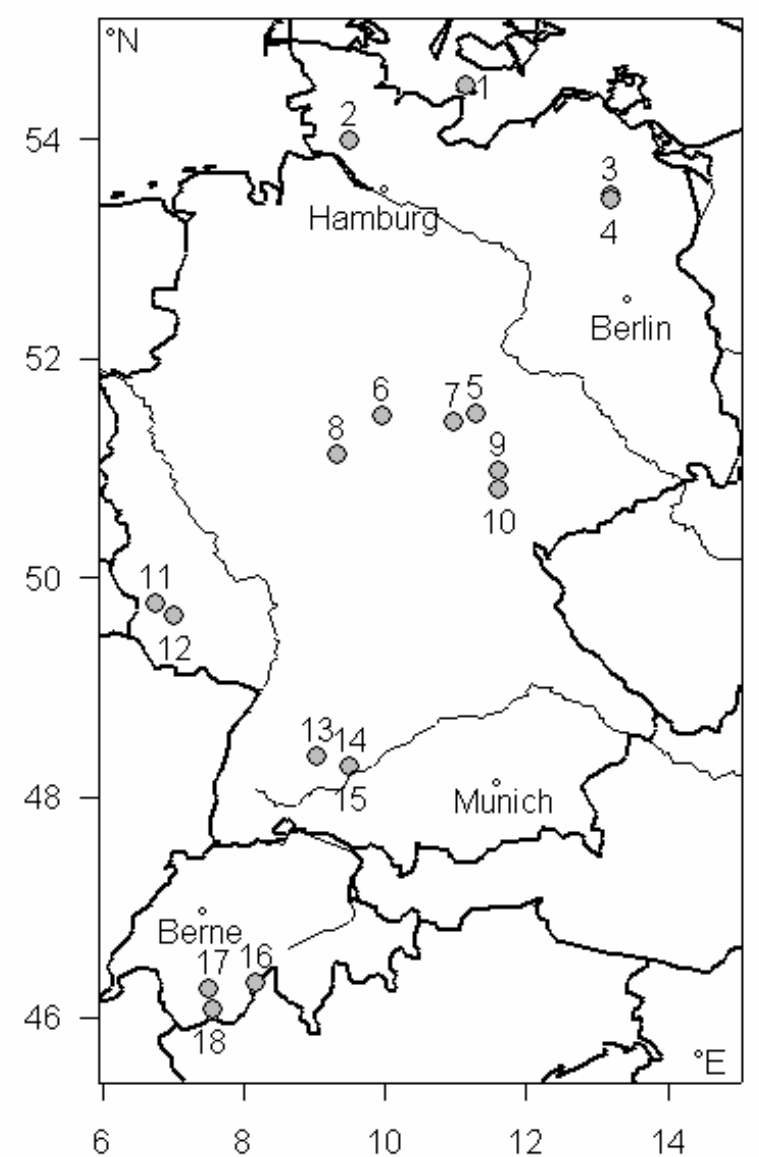

Figure 1. Location of the sampling sites in Germany and Switzerland. In Germany we sampled only sites where $R$. rubiginosa, $R$. corymbifera and $R$. canina occurred together.

The hips were transported in perforated plastic bags to the laboratory and kept at $5{ }^{\circ} \mathrm{C}$. Larvae were allowed to leave the fruits and to pupate. We stored pupae at $-80^{\circ} \mathrm{C}$. Frozen pupae were homogenised in $25-60 \mu 1$ grinding buffer depending on the size of the pupae.

Procedures for cellulose acetate electrophoresis followed Richardson, Baverstock \& Adams (1986) and Hebert \& Beaton (1989; Table 1). Genotypes of individuals are available upon request. Five of the nine putative loci, which produced repeatable and interpretable banding patterns, were polymorphic (95\% criterion). Standard measures of genetic variability and related information (mean number of alleles per locus: $A$; mean expected heterozygosity: $H_{\text {exp }}$; mean observed heterozygosity: $H_{\mathrm{obs}}$, mean number of individuals per locus: $N$ ) were 
calculated using BIOSYS-2 (Black, 1997). Departure from Hardy-Weinberg-equilibrium for each locus within each population (Germany) or site (Valais) was tested using $\chi^{2}$-tests (Swofford \& Selander, 1981). Significance was evaluated using a sequential Bonferroni procedure for Germany as well as Valais ( $p<0.05$; Rice 1989). Tests for linkage disequilibria between pairs of loci within each population or site were performed as implemented in FSTAT (Goudet, 1995; with sequential Bonferroni procedure). We correlated the mean $H_{\text {obs }}$ obtained for the 30 populations across Germany with latitude. Furthermore, we correlated the observed heterozygosity over all 18 samples with latitude (mean of populations of 15 German sites and 3 Swiss sites). Differences in genetic variability between populations from different hosts were tested after correcting for possible influences of sample size or geography (ANCOVA; STATISTICA 6.1; StatSoft, 2002).

Table 1. Enzyme systems, EC number, locus designation, buffer systems and running time for electrophoresis. Number of alleles detected per locus is given in the last column (Richardson et al. 1986). Buffer used: Tris Maleate (TM), $\mathrm{pH}=7$; Tris Glycine (TG), $\mathrm{pH}=8.5$; Tris Citrate $(\mathrm{TC}), \mathrm{pH}=8.2$. Buffer recipes were taken from Richardson et al. (1986), staining procedures followed Hebert \& Beaton (1989) and Richardson et al. (1986).

\begin{tabular}{lllccc}
\hline Enzyme system & EC No. & Locus & Buffer & $\begin{array}{c}\text { Running time } \\
\text { (min) }\end{array}$ & No. of alleles \\
\hline Aspartate Aminotransferase & 2.6 .1 .1 & AAT-2 & TG & 45 & 3 \\
Glycerol-3-phosphate Dehydrogenase & 1.1 .1 .8 & GPDH & TC & 45 & 1 \\
Malate Dehydrogenase & 1.1 .1 .37 & MDH-1 & TM & 45 & 1 \\
& & MDH-2 & TM & 45 & 3 \\
Peptidase C & 3.4 .11 & PEP-C1 & TC & 20 & 1 \\
& & PEP-C2 & TC & 20 & 1 \\
Peptidase D & & PEP-D & TC & 45 & 2 \\
Phosphoglucomutase & 5.4 .2 .2 & PGM & TM & 45 & 4 \\
6-phosphogluconate Dehydrogenase & 1.1 .1 .44 & 6PGDH & TC & 45 & 2 \\
\hline
\end{tabular}

F-statistics were calculated in FSTAT 2.9.3 (Goudet 1995) according to Weir \& Cockerham (1984). For the samples from Germany we estimated hierarchical F-statistics (Weir \& Cockerham, 1984) as implemented in ARLEQUIN 2.001 (Schneider, Roessli \& Excoffier, $2000)$ to evaluate the genetic differentiation between populations within sites $\left(F_{\mathrm{PS}}\right)$ and between sites $\left(F_{\mathrm{ST}}\right)$. Significance of $F$-values was evaluated over all loci (1023 permutations). Because of missing values we excluded the locus AAT-2. Subsequently, we pooled samples for each site of Germany and estimated relative genetic differentiation between samples within a country $\left(F_{\mathrm{SC}}\right)$ and between countries $\left(F_{\mathrm{CT}}\right)$.

We followed Hutchison \& Templeton (1999) to test for equilibrium between gene flow and genetic drift across sites. This approach is based on the "stepping stone" model (Nei, 1987; Maynard Smith, 1989; Wright, 1932). We pooled all samples from a site. Firstly, we correlated pairwise $F_{\mathrm{ST}}$-values versus geographic distance between all pairs of the 15 German 
sites. Significance of the correlation was tested with 999 matrix permutations. Secondly, we

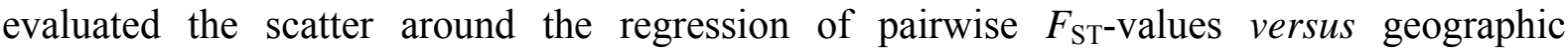
distances. If populations are in equilibrium between gene flow and drift, the scatter of the pairwise $F_{\mathrm{ST}}$-values around the regression line should increase with geographic distance. To test for an increase of scatter with geographic distance we correlated the absolute residuals obtained from standard linear regression versus geographic distances. We also tested for "isolation by distance" using all 15 sites sampled in Germany and the three sites sampled in Valais.

Phenological differences between host plants may vary with latitude with phonological differences at more northern sites. Hence formation of host races may depend on latitude. We tested for a geographical pattern in genetic differentiation between populations on different host species by relating genetic differentiation between populations within sites $\left(F_{\mathrm{PS}}\right)$ versus latitude. We estimated $F_{\mathrm{PS}}$ from separate $F$-statistics for each site with more than one population.

\section{Results}

In 11 out of 149 tests for the populations sampled in Germany (7.4\%, sequential Bonferroni correction) we found significant deviations from Hardy-Weinberg-equilibrium. Significant linkage disequilibria between loci were found only for two comparisons (296 tests; sequential Bonferroni correction). In two Swiss samples we found deviations from Hardy-Weinbergequilibrium (15 tests; sequential Bonferroni procedure). We found no linkage disequilibria between the loci for these data. Overall that data conform the basic assumptions of population genetic analyses.

Standard measures of genetic variability of Rh. alternata are given in the Appendix. Across the 30 populations sampled in Germany the average number of alleles per locus $(A)$ increased with sample size $\left(r^{2}=0.17, p=0.02, n\right.$ ranged from 8 to 63 individuals population ${ }^{-1}$; using sites of Germany and Valais: $r^{2}=0.39, p<0.01, n$ between 13 to 90 individuals site ${ }^{-1}$ ). Expected heterozygosity $\left(H_{\text {exp }}\right)$ as well as observed heterozygosity $\left(H_{\text {obs }}\right)$ were not correlated to sample size (mean $H_{\text {exp }}=0.197 \pm 0.069 ; r^{2}=0.05, p=0.22 ;$ mean $H_{\text {obs }}=0.191 \pm 0.072$; $\left.r^{2}=0.01, p=0.65\right)$. After correcting for sample size the three measures of genetic variability showed no consistent relationship with latitude (ANCOVA; type $1 \mathrm{SS} ; p>0.06$ for $A, H_{\exp }$, $\left.H_{\text {obs }}\right)$ nor any difference between rose species ( $p>0.5$ in all three cases correcting for sample size and latitude). After calculating $A, H_{\text {exp }}, H_{\text {obs }}$ for sites in Germany and including the data 
from Valais we again failed to find any trend in genetic variability with latitude (after correcting for sample size; $p>0.2$ in all three cases).

Hierarchical $F$-statistics indicated moderate genetic differentiation between German populations $\left(F_{\mathrm{PT}}=0.027, p<0.0001\right)$. Genetic differentiation between populations within sites was much lower than the differentiation between sites (within sites: $F_{\mathrm{PS}}=0.009$, $p<0.05$; between sites: $\left.F_{\mathrm{ST}}=0.018, p<0.05\right)$. Nevertheless, the differentiation between populations within sites, that is the differentiation between host plants, was significant. Differentiation between populations within sites did not correlate with latitude $\left(r^{2}=0.22\right.$, $p=0.19,9$ sites with more than one host species; see Appendix).

Because of this low differentiation, we pooled for the broader geographic analysis all data from a single site. Genetic differentiation between the three Swiss sites was not significant $\left(F_{\mathrm{ST}}=0.009 \pm 0.009, p>0.05\right)$. Although Swiss and German samples are separated by the Alps, hierarchical $F$-statistics showed surprisingly low genetic differentiation between countries $\left(F_{\mathrm{CT}}=0.024 ; p<0.05\right)$ which is of about the same magnitude as the differentiation between sites within countries $\left.F_{\mathrm{SC}}=0.022 ; p<0.0001\right)$. Note that this estimate is close to corresponding estimate for the German samples (see above; $F_{\mathrm{ST}}=0.018$ ).
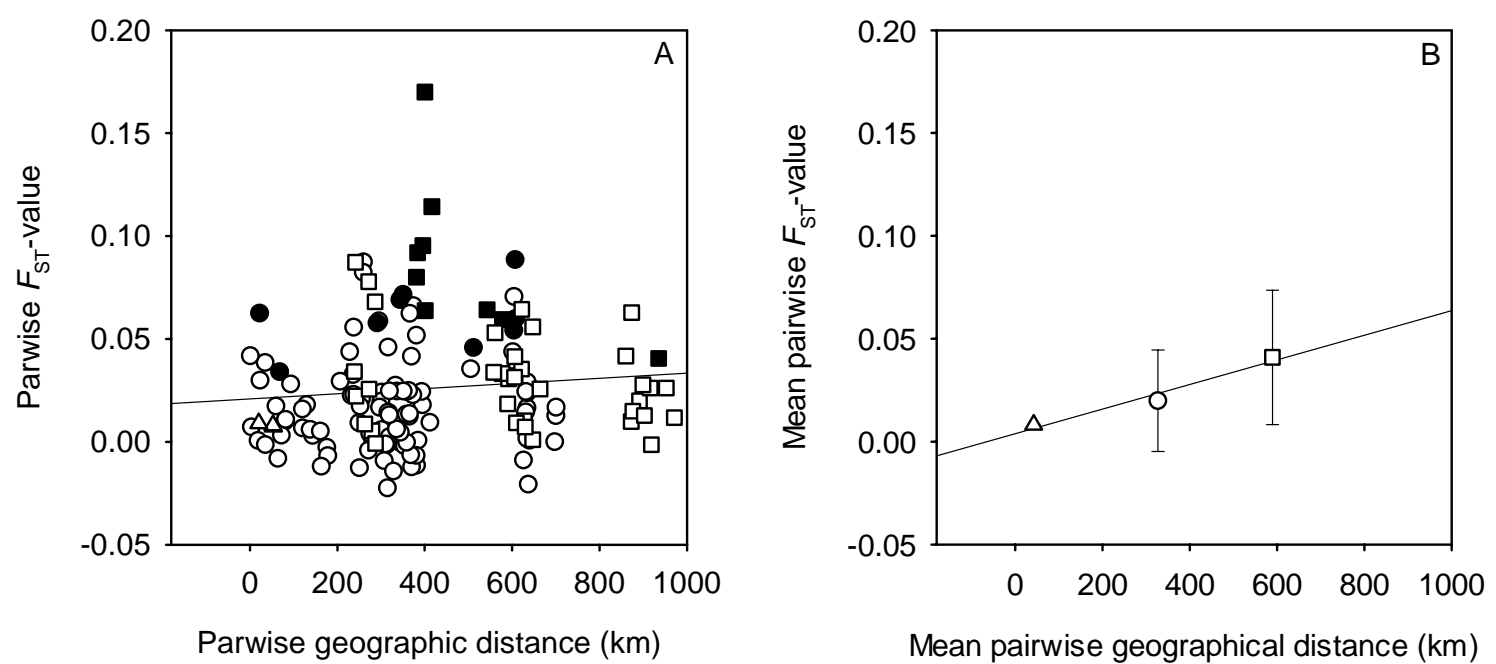

Figure 2. (A) Matrix correlation of pairwise $F_{\mathrm{ST}}$-values of German and Swiss Rhagoletis alternata populations versus pairwise geographical distances between 18 sites $\left(r^{2}=0.01 ; p=0.2\right.$ one-tailed test, one - tailed test, 999 permutations). Circles $=$ comparisons between German sites, triangles $=$ comparisons between Swiss sites, squares $=$ comparisons between German and Swiss populations. Pairwise $F_{\mathrm{ST}}$ values which differ significant from zero are filled. (B) Means across the three different types. Circle = mean of comparisons between German populations, triangle $=$ mean of comparisons between Swiss populations, square $=$ mean of comparisons between German and Swiss populations, Standard errors are given for illustrative reasons.

There was no significant increase of pairwise $F_{\mathrm{ST}}$ - values with geographical distances across sites of Germany (across Germany: $r^{2}<0.01, p=0.28$, across Gremany and Valais: $r^{2}=0.01 ; p=0.2$, one - tailed test, 999 permutations; Fig. 2A). We found no significant increase of scatter with geographic distance (Germany: $r^{2}=0.01, p=0.2$, Germany and 
Valais: $r^{2}<0.001 ; p=0.5$, one tailed test, 999 permutations, not illustrated). However, after calculating means there was a clear increase of genetic differentiation with distance (Fig. 2B).

\section{Discussion}

Our results provide two unexpected findings. Firstly we found significant genetic differentiation between populations from different host species. However, the differentiation was very low. Secondly, we found surprisingly little geographic structure of genetic differentiation between populations of this fruit fly across central Europe.

Our analyses indicated that genetic differentiation between populations sampled on different rose species was significant. However, the amount of differentiation was such low that it is not warranted to interpret this as an indication of host races. We suggest three possible reasons to explain our failure to detect host races. First, the association between the fly and the host is very young. Second, the marking of fruits by the females increases mixing between populations. Third, the permanent and ongoing hybridisation between rose species of the section Caninae prevents formation of host races. The first reason is not convincing. Rh. pomonella was able to form host races with clear differences in the frequencies of allozyme alleles within less than 150 years (Bush, 1968). The association between Rh. alternata and roses should be much older. Hence, within the given time frame the formation of host race should have been possible. Second, as far as we know all species in the genus Rhagoletis mark fruits, in which female flies have just laid an egg, with a pheromone. $R h$. pomonella also marks the fruits and one may conclude that the pheromone itself does not enforce a mixing between populations. But note the differences in the size of fruits attacked by Rh. pomonella (apple - large) and Rh.alternata (hips - small). On large fruits the pheromone system may be much less effective than on small fruits. Furthermore, the pheromone may only enforce a mixing between populations on different hosts if fruits for eggs are available simultaneously. Thus, the pheromone may preclude the formation of host races only between hosts with a small difference in the phenology of fruit production. The last argument for the low genetic differentiation between populations from the three host plants is based on the ongoing and permanent hybridisation between roses. The permanent gene flow and the reticulated speciation process may act as a "hybrid bridge". This may homogenize populations as well as the composition of the whole exploiter community. A field survey of the arthropods associated with the three dog roses across Germany found also little differences in the density and composition of arthropods between the three rose species (Fricke et al., unpublished data). This supports on the level of the exploiter community our 
findings on the level of population genetics. Nevertheless, a strong selection for specific adaptations to certain hosts may counteract homogenisation. In the case of $R h$. pomonella gene flow between host races on Crataegus and Malus was found, but selection on emergence time seems to change as a by-product allele frequency of allozymes linked to fitness genes (Feder, Hunt \& Bush, 1993; Feder et al., 1997; Diegisser et al., 2004). The differences in the ripening of the fruits may be not sufficiently different to select for host races in Rh. alternata. Next we want to discuss the lack of geographic structure across central Europe. To explain the low genetic differentiation between populations as well as the lack of isolation by distance one may use the arguments in Hutchison \& Templeton (1999). These authors argue that low genetic differentiation and lack of isolation by distance points to a recent range expansion. We failed to demonstrate an increase of differentiation with geographic distance. Furthermore, we found also no increase in the scatter of the pairwise $F_{\mathrm{ST}}$-values around the relationship of differentiation versus geographic distance with increasing distance, which is a hint that populations are not in equilibrium. Overall, the patterns of genetic variation between populations point to a range expansion of the fruit fly. The roses, and very likely also their exploiters, expanded their range to central and northern Europe after the last glaciation. One may argue that such a time span should be sufficient for an insect to reach equilibrium. However, populations of Rh. alternata are large: All fruits of a bush may be infested by larvae (own observations). Large population sizes are not unusual for Rhagoletis. Smith for example (cited in McPheron et al., 1988a) collected all fruits from a single Crataegus individual and from the 8926 collected fruits, he obtained 5416 pupae of Rh. pomonella. The time (in generation) to reach equilibrium between gene flow and drift increases with population size and may take a very long time for large populations (e.g. Whitlock \& McCauley 1999). Population sizes of 10000 individuals at a site and even more are consistent with the hypothesis that fly populations have not yet reached equilibrium between gene flow and drift after the post-pleistocene range expansion.

Large populations are less prone to genetic drift than small populations. Given the large population sizes in Rh. alternata, gene flow is more important to understand population genetic patterns than drift (Roderick, 1996; Rousset, 1997; Hewitt, 2004). Large populations may also generate more gene flow, especially in populations with limited resources. Remember that females mark hips in which they laid an egg. Female flies may leave localities with a high proportion of infested fruits (Roitberg et al., 1982; Bauer, 1986, 1998). Combined with a high population size such behaviour may increase dispersal between populations. Low genetic differentiation between populations is not unusual within the Tephritidae (see 
Berlocher, 1984; McPheron et al., 1988a, 1988b; Eber Sturm \& Brandl, 1991; Eber \& Brandl, 1992; Eber \& Brand1, 1997, Itami et al., 1998; Berlocher, 1999; Berlocher, 2000 and references therein; Schwarz et al., 2003; Diegisser et al., 2004). Nevertheless, we found evidence for restricted gene flow between German and Swiss samples: Genetic differentiation between countries was of about the same magnitude as the differentiation between sites across Germany. The Alps seem to be some kind of barrier, but nevertheless the genetic difference between populations on both sides of the Alps is still surprisingly low when compared to differentiations of other insects (e.g. Schmitt \& Seitz, 2001).

Leclaire \& Brandl (1994) analysed the genetic differentiation of Rh. alternata between the hosts R. canina and R. rugosa, an species imported from Asia about 100 years ago. These authors also failed to find marked genetic differentiation between populations associated with each rose species. Overall all these results suggest considerable gene flow between populations of Rh. alternata across spatial scales of up to $1000 \mathrm{~km}$. This gene flow, the limited phenological differences between host species and the ongoing hybridisation of hosts may prevent the formation of genetic differences between populations of exploiters on rose species.

Acknowledgements We thank Melanie Klose, Sabrina Brückmann and Roman Fricke for help during field work. Andreas Marten commented on the manuscript. The work was supported by the Deutsche Forschungsgemeinschaft (DFG) within the Priority Programme SPP 1127 (Adaptive Radiation - Origin of Biological Diversity)

\section{References}

Bauer G. 1986. Life history strategy of Rhagoletis alternta, a fruit fly operating in a "noninteractive" system. Journal of Animal Ecology 55:785-794.

Bauer G. 1998. Structure and function of a non-interactive, reactive insect-plant system. Oecologia 115:154-160.

Berlocher SH. 1984. Genetic changes coinciding with the colonization of California by the walnut husk fly, Rhagoletis completa. Evolution 38: 906-918.

Berlocher SH. 1999. Host races or species? Allozyme characterization of the "flowering dogwood fly", a member of the Rhagoletis pomonella complex. Heredity 83: 652-662.

Berlocher SH. 2000. Radiation and divergence in the Rhagoletis pomonella species group: Inferences from allozymes. Evolution 54: 543-557. 
Black WC IV. 1997. BIOSYS-2. A computer program for the analysis of allelic variation in genetics. Ft. Collins, Co: Colorado State University.

Bush G. 1968. Sympatric host race formation and speciation in frugivorous flies of the genus Rhagoletis (Diptera: Tephritidae). Evolution 23: 237-251.

Diegisser T, Johannesen J, Lehr C, Seitz A. 2004. Genetic and morphological differentiation in Tephritis bardanae (Diptera: Tephritidae): evidence for host-race formation. Journal of Evolutionary Biology 17: 83-93.

Diehl SR, Bush GL. 1984. An evolutionary and applied perspective of insect biotypes. Annual Review of Entomology 29: 471-504.

Drès M, Mallet J. 2002. Host races in plant-feeding insects and their importance in sympatric speciation. Philosophical Transactions of the Royal Society of London 357: 471-492.

Eber S, Sturm P, Brandl R. 1991. Genetic and morphological variation among biotypes of Tephritis bardanae. Biochemical Systematics and Ecology 19: 549-557.

Eber S, Brandl R. 1992. Genetic and morphological variation among populations of Oxyna parietina (Diptera: Tephritidae) across a European transect. Canadian Journal of Zoology 70: 1120-1128.

Eber S, Brandl R. 1997. Genetic differentiation of the tephritid fly Urophora cardui in Europe as evidence for its biogeographical history. Molecular Ecology 6: 651-660.

Feder JL, Hunt TA, Bush GL. 1993. The effects of climate, host plant phenology and host fidelity on the genetics of apple and hawthorn infesting races of Rhagoletis pomonella. Entomologia Experimentalis et Applicata 69: 117-135.

Feder JL, Roethele JB, Wlazo B, Berlocher SH. 1997. Selective maintenance of allozyme differences between sympatric host races of the apple maggot fly. Proceedings of the National Academy of Sciences.94: 11417-11421.

Goudet J. 1995. FSTAT, Version 1.2: A computer program to calculate F-Statistics. Journal of Heredity 86: 485-486.

Hebert PDN, Beaton MJ. 1989. Methodologies for allozyme analysis using cellulose acetate electrophoresis. Beaumont, Texas: Helena Laboratories.

Hewitt GM. 2004. Genetic consequences of climatic oscillations in the Quaternary. Transactions of the Royal Society of London Series B-Biological Sciences 359: 183-195.

Hutchison DW, Templeton AR. 1999. Correlation of pairwise genetic and geographic distance measures: inferring the relative influences of gene flow and drift on the distribution of genetic variability. Evolution 53:1898-1914. 
Itami J, Craig TP, Horner J. 1998. Factors affecting gene flow between the host races of Eurosta solidaginis. In: Mopper S, Strauss SY, eds. Genetic structure and local adaptation in natural insect populations., New York, Albany, Bonn, Boston, Cincinnati, Detroit, London, Madrid, Melbourne, Mexico City, Pacific Grove, Paris, San Francisco, Singapore, Tokyo, Toronto, Washington: Chapman \& Hall, 375-404.

Leclaire M, Brandl R. 1994. Phenotypic plasticity and nutrition in a phytophagous insect: consequences of colonizing a new host. Oecologia 100: 379-385.

Maynard Smith J.1989. Evolutionary Genetics. Oxford: Oxford University Press.

McPheron BA, Smith DC, Berlocher SH. 1988a. Microgeographic genetic variation in the apple maggot Rhagoletis pomonella. Genetics 119: 445-451.

McPheron BA, Smith DC, Berlocher SH. 1988b. Genetic differences between host races of Rhagoletis pomonella. Nature 336: 64-66.

Nei M. 1987. Molecular Evolutionary Genetics. New York: Columbia University Press.

Rice WR. 1989. Analysing tables of statistical tests. Evolution 43: 223-225

Richardson BJ, Baverstock PR, Adams M. 1986. Allozyme Electrophoresis. A Handbook for animal systematics and population studies. London: Academic Press.

Ritz CM, Wissemann V. 2003. Male correlated non-matroclinal character inheritance in reciprocal hybrids of Rosa section Caninae (DC.) Ser. (Rosaceae). Plant Systematics and Evolution 241: 213-221.

Ritz CM, Schmuths H, Wisseman V. 2005. Evolution by reticulation: European dogroses originated by multiple hybridisation across the genus Rosa. Journal of Heredity 96: 414.

Roderick GK. 1996. Geographic structure of insect populations: Gene flow, phylogeography, and their uses. Annual Review of Entomology 41: 325-352.

Roitberg BD, Van Lenteren JC, Van Alphen JM, Galis F, Prokopy RJ. 1982. Foraging behaviour of Rhagoletis pomonella, a parasite of hawthorn in nature. Journal of Animal Ecology 51: 307-325.

Rousset F. 1997. Genetic differentiation and estimation of gene flow from F-statistics under isolation by distance. Genetics 145: 1219-1228.

Schmitt T, Seitz A. 2001. Allozyme variation in Polyommatus coridon (Lepidoptera : Lycaenidae): identification of ice-age refugia and reconstruction of post-glacial expansion. Journal of Biogeography 28: 1129-1136.

Schneider S, Roessli D, Excoffier L. 2000. ARLEQUIN - A software for population genetics data analysis, Version 2.001. 
Schwarz D, McPheron BA, Hartl GB, Boller EF, Hoffmeister TS. 2003. A second case of genetic host races in Rhagoletis? A population genetic comparison of sympatric host populations in the European fruit fly, Rhagoletis cerasi. Entomologia Experimentalis et Applicata 108: 11-17.

StatSoft. 2002. STATISTICA, Version 6.1. Statistica for Windows.

Täckholm G. 1920. On the cytology of the genus Rosa. A preliminary note. Svensk Botanisk Tidskrift 14: 300-311.

Täckholm G. 1922. Zytologische Studien über die Gattung Rosa. Acta Horti Bergiani 7: 97381.

Thompson JN. 1994. The coevolutionary process. Chicaco, London: The University of Chicaco Press.

Weir BS, Cockerham CC. 1984. Estimating F-Statistics for the analysis of population structure. Evolution 38: 1358-1370.

Whitlock MC, McCauley DE. 1999. Indirect measures of gene flow and migration: $F_{\mathrm{ST}} \neq$ 1/(4Nm+1). Heredity 82: 117-125.

Wissemann V. 2000. Molekulargenetische und morphologisch-anatomische Untersuchungen zur Evolution und Genomzusammensetzung von Wildrosen der Sektion Caninae (DC.) Ser. Botanische Jahrbücher für Systematik, Pflanzengeschichte und Pflanzengeographie 122: $357-429$.

Wissemann V. 2002. Molecular evidence for allopolyploid origin of the Rosa canina-complex (Rosaceae, Rosoideae). Journal of Applied Botany 76:176-178.

Wissemann V, Ritz CM. 2005. The genus Rosa (Rosoideae, Rosaceae) revisted: molecular analysis of nrITS-1 and atpB-rbcL intergenetic spacer (IGS) versus conventional taxonomy. Botanical Journal of Linnean Society 147: 275-290.

Wright S. 1932. The roles of mutation, inbreeding, crossbreeding and selection in evolution. Proceedings of the Sixth International Congress of Genetics 1: 356-366.

Zwölfer H. 1974. Das Treffpunkt-Prinzip als Kommunikationsstrategie und Isolationsmechanismus bei Bohrfliegen (Diptera: Trypetidae). Entomologica Germanica 1:11-20. 


\section{Appendix}

Sample sites, populations and standard measures of genetic variability (including monomorphic loci; \pm standard error) for 30 populations of Rhagoletis alternata from three host species of the genus Rosa and for the three valleys of Valais (Switzerland, here we pooled all data from a single site). $n=$ sample size, $N=$ mean number of individuals per locus, $A=$ mean number of alleles per locus, $H_{\text {exp }}=$ mean expected heterozygosity, $H_{\text {obs }}=$ mean observed heterozygosity; site codes: 1=Fehmarn, 2= Pöschendorf, $3=$ Tollense See, $4=$ Krickow, $5=$ Sangerhausen, $6=$ Gartetal, $7=$ Kelbra, $8=$ Cappel, $9=$ Jena Zwätzen, $10=$ Kahla, $11=$ Trier Goldberg, $12=$ Trier Züsch, $13=$ Beurener Heide, $14=$ Hayingen Lauterdörfle, $15=$ Hayingen Lautertal, $16=$ Ulrichen, $17=$ Lötschental, $18=$ Saastal (see also Figure 1)

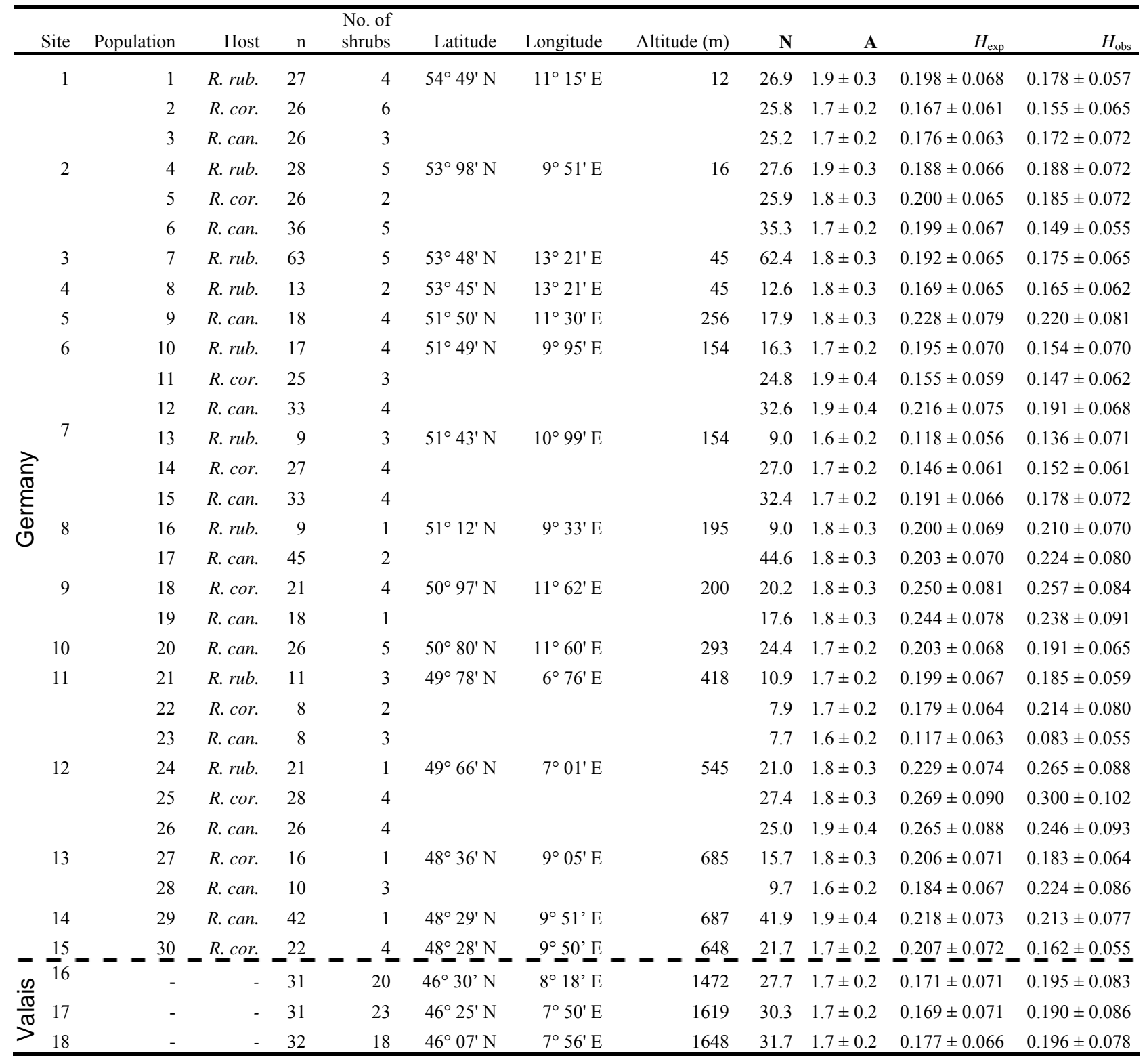




\section{Zusammenfassung}

Phänotypen von nah verwandten Pflanzenarten können höhere trophische Ebenen beeinflussen. Multitrophische Interaktionen zwischen Wirtspflanzenarten, Herbivoren und ihren Gegenspielern können sich nicht nur mit phänotypischen Unterschieden zwischen Wirtspflanzenarten ändern, sondern auch mit der geographischen Lage. Studien von Konsumenten und ihren Gegenspieler auf verwandten Wirtspflanzen entlang geographischer Gradienten können helfen die relative Wichtigkeit der jeweiligen Prozesse einzuschätzen. In dieser Arbeit wurde untersucht, wie sich die phänotypische Vielfalt von Hundsrosen auf die höheren trophischen Ebenen auswirkt. Hundrosen zeichnen sich durch hohe geno- und phänotypische Vielfalt aus. Durch ihre charakteristische Art der Vererbung sind sie in ihrem Genom durch die Mutterpflanze bestimmt. Die meisten Pflanzeneigenschaften, wie z.B. die drüsigen Haare auf der Blattunterseite, sind matroklinal vererbt. Die Untersuchungen beschränkten sich auf drei phänotypisch unterschiedliche Hundsrosenarten (auf der Blattunterseite: kahl - Rosa canina, haarig - R. corymbifera, mit drüsigen Haaren R. rubiginosa).

Es wurde zum einen die Häufigkeit von drei Konsumentenarten, von der Fruchtfliege Rhagoltis alternata, der Gallwespe Diplolepis rosae und dem Rostpilz Phragmidium spp., und zum anderen die genetische Differenzierung von Rh. alternata, Unterschiede in der Gallgesellschaft von D. rosae und Unterschiede in Invertebraten Gesellschaften auf den drei Rosenarten an unterschiedlichen Standorten in Deutschland und der Schweiz analysiert. Die Ergebnisse zeigten, dass die Häufigkeit der drei Konsumenten zwischen den Rosenarten und der geographischen Lage variierte. Rh. alternata und D. rosae hatten die höheren Dichten auf $R$. rubiginosa und Phragmidium spp. auf $R$. canina und R. corymbifera. Der Erklärungswert der Varianz für den Faktor Rosenart nahm von Rh. alternata über D. rosae bis Phragmidium spp. zu und nahm in derselben Reihenfolge für den Faktor Standort ab. Rh. alternata, mit nur geringer Wirtsspezialisierung, hatte keinen Einfluss auf die Wirtspflanzen, trotz hoher Befallsraten. Phragmidium spp., mit einer hohen Wirtsspezialisierung und hohen Befallsraten, beeinflusste die Fitness der Wirtspflanzen im darauf folgenden Jahr negativ. D. rosae zeigte, vermutlich aufgrund geringer Dichte, intermediäre Muster. Die Ergebnisse unterstützen die Annahme, dass nur bei interaktiven Systemen ein Wettrüsten zwischen Pflanze und Konsumenten auftritt. Populationen von Rh. alternata zeigten eine geringe genetische Differenzierung zwischen den drei Wirtspflanzenarten und über den geographischen Gradienten. Erklärungen dafür sind erstens ein hoher Genfluss zwischen den Populationen von Rh. alternata, zweitens eine kürzliche 
Ausweitung des Verbreitungsgebietes von Rh. alternata und drittens ständiger Genfluss zwischen den Rosenarten der Sektion Caninae, der damit als Hybridbrücke fungiert. Die Untersuchung der Herbivore-Parasitoid Gesellschaft in D. rosae Gallen zeigte, dass die Überlebensrate von $D$. rosae auf $R$. rubiginosa am höchsten, die der Parasitierung dort am niedrigsten war. R. rubiginosa scheint, vermutlich durch die drüsige Behaarung, ein Zufluchtsort für D. rosae zu sein. Mit steigendem Gallvolumen verringerte sich auf allen drei Rosen die Parasitierung. Der Einfluss der Wirtspflanze änderte sich nicht mit der geographischen Lage. Die einzelnen Parasitoidarten zeigten artspezifische Muster und unterstützten damit die Koexistenz in den Gallen. Die trophischen Interaktionen in den D. rosae Gallen wurden auch mit Veränderung der geographischen Lage prägnant durch die Wirtspflanze beeinflusst. Die ektophytischen Invertebraten Gesellschaften auf den drei Rosenarten zeigten nur geringe Unterschiede in der Komposition der Gesellschaft und in der Abundanz der Gruppen Aphidina, Collembola, Araneae, Hymenoptera und Coleoptera. Die taxonomische Einteilung ist vermutlich $\mathrm{zu}$ grob, so dass eventuelle artspezifische Unterschiede in einzelnen Insektenarten oder Phytophagenarten nicht gezeigt werden konnten.

Es wurde außerdem untersucht, ob Hundsrosenhybride anfälliger gegen Insektenfraß sind. Der Blattkonsum der drei Rosenarten und ihren Hybriden wurde mit dem Generalisten Spodoptera littoralis analysiert. Es zeigten sich keine Fraßunterschiede zwischen NichtHybriden und Hybriden. Wichtiger waren an die Hybride vererbte Eigenschaften der Rosenarten, wie z.B. drüsige Haare, wodurch die Hybriden in ihrem Phänotyp und in der Fraßmenge der Mutterpflanze ähnelten. Dieses Ergebnis zeigt, dass im System der Hundrosen Herbivorie nicht $\mathrm{zu}$ einer Stabilisierung der Arten führt, sondern Hybridisierung von Hundsrosenarten die Basis für die Ausbildung der Artenvielfalt bei Hundrosen ist.

Die phänotypischen Unterschiede zwischen den untersuchten Rosenarten übertrugen sich auf die höheren trophischen Ebenen, wenn der Konsument Ressourcen nutzte, die phänotypische Unterschiede zeigten. Unterschiede in den nächsten trophischen Ebenen zeigten sich immer zwischen $R$. rubiginosa und den anderen beiden Rosenarten, wahrscheinlich durch den phänotypischen Unterschied in der Behaarung auf der Blattunterseite.

Multitrophische Interaktionen zwischen Pflanzen, Herbivoren und Gegenspielern können die Verteilung von Herbivoren auf unterschiedlichen Wirtspflanzenarten beeinflussen. Untersuchungen auf unterschiedlichen Skalen, wie die der Pflanzenart, dem Konsumententyp und die geographische Lage, können erst die Beziehung zwischen Wirtspflanzen und Herbivoren aufzeigen. 
Weitere Untersuchungen sind notwendig, um zu analysieren, inwieweit Herbivore und Gegenspieler direkt auf die drüsigen Haare und ihre Inhaltsstoffe reagieren. Weiterhin sollten Untersuchungen zu Pflanzen-Herbivoren Interaktionen sich nicht auf einfache Interaktionen beschränken, sondern multitrophische Interaktionen auf unterschiedlichen Skalen berücksichtigen, um die tatsächliche Komplexität zu erfassen. 


\section{Summary}

The phenotypes of closely related plant species have been shown to affect higher trophic levels. Multitrophic interactions between host plant species, herbivores and natural enemies may change depending on phenotypic differences between the host plant species and their geographical location. Studying consumers and their natural enemies on related host plants across geographical gradients can help to evaluate the relative importance of the different interactions. During this study it was investigated how the phenotypic plasticity of dog roses affects next trophic levels. Dog roses form a taxon of closely related species with a big variety of pheno- and genotypic plasticity. They are characterised by a heterogamous meiosis, which generates offspring dominated by the genome of the mother. Most plant traits, including the type of trichomes on the lower leaf surface are matroclinally inherited. The study focuses on three closely related dog rose species which differ in their phenotypes (on the lower leaf surface: glabrous - Rosa canina, hairy - R. corymbifera, glandular scented - R. rubiginosa).

Density variations of three consumer species, of the tephritid fly Rhagoletis alternata, the cynipid wasp Diplolepis rosae and the rust fungus Phragmidium spp. was analysed and further the genetic differentiation of Rh.alternata, the differentiation in the associated parasitoid community of $D$. rosae and differences in invertebrate communities on the three rose species on different sites across Germany and Switzerland. The results show that the densities of the three consumer species varied between host plant species and geographical locations. Rh. alternata and D. rosae showed higher densities on R. rubiginosa, while Phragmidium spp. showed higher density on $R$. canina and $R$. corymbifera. The relative amount of variance of density accounted for host plant species increased from Rh. alternata to D. rosae and Phragmidium spp., and decreased in the same following by geographical location. Little host plant specialisation of Rh. alternata was linked to little impact on host performance despite high densities of Rh.alternata, whereas high specialisation of Phragmidium spp. was related to high host impact reducing hip density and leaf cover in the following year. D. rosae galls showed intermediate patterns. This is in line with the concept of interactive systems locked in a highly specialised plant-consumer arms race, in contrast to non-interactive systems. The genetic differentiation of Rh. alternata between populations was very low on the three host species and across central Europe. There are three possible explanations for this low genetic differentiation. First, the gene flow between populations of Rh. alternata must be high. Second, the pattern of genetic differentiation is based on recent expansion of the distributional range of Rh. alternata and the ongoing gene flow between rose species of section Caninae act as a hybrid bridge. The scented R. rubiginosa showed 
remarkably higher gall densities, than $R$. canina and R. corymbifera. The survival rate of $D$. rosae was highest and percent parasitism lowest on $R$. rubiginosa. Hence, this rose species appeared to provide an important refuge for the gall-maker population. The glabrous trichomes of $R$. rubiginosa and the correspondingly smelling galls may have been the reason for the low parasitism. The percent parasitism was in all three rose species highest in small galls, presumably due to limiting length of the parasitoids ovipositor. Gall-parasitoid interactions did not change with geographical position. The parasitoid species showed species-specific differences in host use, thereby contributing to the coexistence on this species-rich parasitoid community. The trophic interactions were driven by host plant identity, not by geographical location. The invertebrate communities showed only minor differences in the abundances of invertebrate taxa (Aphidina, Collembola, Aranea, Hymenoptera and Coleoptera) between the three rose species. Ordination also showed few differences in the composition of the communities. Maybe possible species-specific differences of insect and phytophagous species could not be shown on this taxonomic level.

To investigate if hybridisation of dog roses results in changes of palatability to insect herbivory, the leaf consumption by Spodoptera littoralis on the three dog rose species and their hybrids was analysed. Leaf consumption showed lower palatability of $R$. rubiginos $a$ and rose hybrids with $R$. rubiginosa as the maternal seed plant. There were no principal differences between hybrids and non-hybrids, but between the rose phenotypes with and without glandular trichomes. Hence, there was no evidence that herbivores contribute to stabilization of rose species identity, but the mother-based phenotype determines rose palatability. This opens a possibility for introgression of new hybridogenic genetic combinations into rose populations and is one basis for the diversity-generating potential of hybridisation.

The phenotypic differences between the investigated rose species translated into next trophic levels, if the consumer used resources, which show different traits between rose species. Differences on the next trophic level always occur between $R$. rubiginosa and the other two rose species, possibly due to the phenotypic differences in the trichomes on the lower leaf surface.

Multitrophic interactions between plants, herbivores and natural enemies affected the distribution of herbivores on the different host plant species. Investigations on different scales, like the host plant species, the consumer type and the geographical location could only reveal the relationship between host plant and herbivore. 
Further studies are needed, which investigate directly the effect of glandular trichomes on higher trophic levels. Further plant-herbivore studies should not be limited on simple interactions, but consider multitrophic interactions on different scales. 


\section{Erläuterung zu eigenen Beiträgen in der Arbeit}

Kapitel 2: Variability in plant-consumer interactions across host species: Comparing fruit flies, gall wasps and rust fungi on wild roses.

- Ausarbeitung der Untersuchung, Erhebung und Auswertung der Daten durch die Autorin

- Verfassen des Manuskriptes in Zusammenarbeit mit Prof. Roland Brandl, Prof. Teja Tscharntke und Dr. Volker Wissemann

- Veröffentlichung: Das Manuskript ist bei Plant Perspectives in Plant Ecology, Evolution and Systematics eingereicht

Kapitel 3: Does hybridisation of dog roses affect insect herbivory?

- Ausarbeitung der Untersuchung, Durchführung und Auswertung der Experimente durch die Autorin

- Verfassen des Manuskriptes in Zusammenarbeit mit Prof. Roland Brandl, Prof. Teja Tscharntke und Dr. Volker Wissemann

Kapitel 4: Cynipid gall-parasitoid interactions, comparing three dog rose species along a geographic gradient.

- Ausarbeitung der Untersuchung, Erhebung und Auswertung der Daten durch die Autorin

- Verfassen des Manuskriptes in Zusammenarbeit mit Prof. Teja Tscharntke und Prof. Roland Brandl

Kapitel 5: Invertebrate communities on three dog roses are not affected by leaf trichome traits of hosts.

- Ausarbeitung der Untersuchung und Durchführung der Datenerhebung durch die Autorin

- Auswertung der Daten durch Roman Fricke im Rahmen seiner Diplomarbeit

- Verfassen des Manuskriptes durch Roman Fricke in Zusammenarbeit mit der Autorin, Prof. Roland Brandl, Prof. Teja Tscharntke und Dr. Volker Wissemann 
Kapitel 6: Genetic differentiation between populations of the European rose hip fly Rhagoletis alternata.

- Ausarbeitung der Untersuchung durch die Autorin, Durchführung der Datenerhebung durch die Autorin und Andrea Vaupel

- Allozymanalysen und Auswertung der Daten durch Andrea Vaupel im Rahmen ihrer Diplomarbeit

- Verfassen des Manuskriptes durch Andrea Vaupel in Zusammenarbeit mit der Autorin, Prof. Roland Brandl, Prof. Teja Tscharntke und Dr. Volker Wissemann

- Veröffentlichung: Das Manuskript ist bei Biological Journal of the Linnean Society eingereicht 


\section{Danksagung}

Mein besonderer Dank gilt Herrn Prof. Dr. Teja Tscharntke (Agrarökologie, Universität Göttingen), der mir die Durchführung dieser Promotion mit der Annahme des Hauptreferates ermöglicht hat und mich mit wissenschaftlichen Diskussionen und Anregungen in Theorie und Praxis unterstützt hat.

Herrn Prof. Dr. Roland Brandl (Allgemeine Ökologie und Tierökologie, Universität Marburg) möchte ich ganz besonders danken. Er hat mich in theoretischen wie praktischen Fragen betreut und durch seine energische Art immer wieder motiviert.

Herrn Dr. Volker Wissemann (Spezielle Botanik, Universität Jena) danke ich für sein Interesse auch an der zoologischen Seite der Wildrosen und seine Anregungen, sowohl während der Datenaufnahme, als auch später in der Aufbereitung der Thematik in Manuskripten.

Frau Prof. Dr. Elke Pawelzik (Agrikulturchemie, Universität Göttingen) danke ich für die Möglichkeit Pflanzenmaterial chemisch analysieren zu können. Frau Dr. Anna Keutgen (Agrikulturchemie, Universität Göttingen) und den Mitarbeiterinnen der Agrikulturchemie danke ich für die eingehende Betreuung im Umgang mit den Analysegeräten und den Datensätzen.

Frau Dr. Christiane Ritz danke ich für die Bestimmung der Rosenarten auf unseren gemeinsamen Sammeltouren. Roman Fricke danke ich für die Übernahme der Auswertung und schriftlichen Darstellung der Daten für die Invertebraten Gesellschaften auf Rosen. Andrea Vaupel danke ich für die Übernahme der Auswertung und schriftlichen Darstellung der Daten bezüglich der genetischen Differenzierung der Hagebuttenfruchtfliege. Diesen dreien und Melanie Klose und Sabrina Brückmann danke ich für die Unterstützung bei den Datenaufnahmetouren.

Sämtlichen MitarbeiterInnen der Agrarökologie in Göttingen und der Tierökologie in Marburg danke ich für das angenehme Arbeitsklima, viele Hilfen und Anregungen.

Prof. Dr. S. Robert Gradstein danke ich für die Möglichkeit, die Hybridrosensammlung von Dr. V. Wissemann im Botanischen Garten in Göttingen anpflanzen zu können, so dass wesentliche Experimenten für meine Arbeit dort stattfinden konnten.

Den Mitgliedern des Arbeitskreises Wildrosenfreunde in Deutschland danke ich für die freundliche Unterstützung meiner Arbeit und für die Hilfe beim Auffinden geeigneter Hundsrosenpopulationen.

Herrn Prof. Dr. Matthias Schaefer (Zoologische Ökologie, Universität Göttingen) danke ich für seine freundliche Übernahme des Korreferats.

Herrn Prof. Stefan Vidal, Herrn Dr. Wolfgang Dröge-Laser, Frau Prof. Dr. Margarete Boos und Herrn Prof. Dr. Peter M. Kappeler danke ich für die Bereitschaft die Prüfungskommission mit zu bilden. 


\section{Publikationen}

\section{Zeitschriften}

\section{Eingereicht}

Klinge, K., Tscharntke, T., Wissemann, V., Brandl, R. Variability in plant-consumer interactions across host species: Comparing fruit flies, gall wasps and rust fungi on wild roses. Perspectives in Plant Ecology, Evolution and Systematics.

Vaupel, A., Klinge, K., Brändl, M., Wissemann, V., Tscharntke, T., Brandl, R. Genetic differentiation between populations of the European rose hip fly Rhagoletis alternata. Biological Journal of the Linnean Society.

\section{In Vorbereitung}

Klinge, K., Thies, C., Tscharntke, T. Tree Sparrows affect biological control of cereal aphids by hoverfly predators.

Klinge, K., Wissemann, V., Brandl, R., Tscharntke, T. Does hybridisation of dog roses affect insect herbivory?

Klinge, K., Wissemann, V., Brandl, R., Tscharntke, T. Cynipid gall-parasitoid interactions, comparing three dog rose species along a geographic gradient.

Fricke, R., Klinge, K., Wissemann, V., Tscharntke, T., Brandl, R. Invertebrate communities on three dog roses are not affected by leaf trichome traits of hosts.

\section{Tagungsbeiträge, Vorträge}

Lehmann, K., Thies, C. \& Tscharntke, T. (2004): Trophische Kaskaden zwischen Getreideblattläusen, Schwebfliegen und Feldsperlingen. Multitrophische Interaktionen Tagung, Göttingen.

Lehmann, K., Wissemann, V., Oberwinkler, F., Brandl, R. \& Tscharntke, T. (2004): Hostparasite interactions in wild rose species and their hybrids. $10^{\text {th }}$ Meeting of $\mathrm{PhD}$ students in Evolutionary Biology, Preston Montford, UK.

Lehmann, K., Thies, C. \& Tscharntke, T. (2004): Insectivorous birds affect potential biocontrol of cereal aphids by syrphid predators. Verhandlung der Gesellschaft für Ökologie, Band 34: 68.

Klinge, K., Tscharntke, T., Wissemann, V., Brandl, R. (2005): Variation in host-exploitation across host and space. ENTO'05 of the Royal Entomological Society, Sussex, UK.

\section{Tagungsbeiträge, Poster}

Lehmann, K., Ritz, C., Wissemann, V., Maier, W., Oberwinkler, Brandl, R. \& Tscharntke, T. (2003): Dog rose-rust fungus-tephritid fly interactions on a geographic scale. Verhandlung der Gesellschaft für Ökologie, Band 33: 177.

Lehmann, K., Brandl, R. \& Tscharntke, T. (2004): Are plant hybrids particularly susceptible to herbivory? Verhandlung der Gesellschaft für Ökologie, Band 34: 139.

Lehmann, K., Thies, C. \& Tscharntke, T. (2005): Tree Sparrows affect biological control of cereal aphids by hoverfly predators. ENTO'05 of the Royal Entomological Society, Sussex, UK. 


\section{Lebenslauf}

Name

Geburtsdatum

Geburtsort

Staatsangehörigkeit

Familienstand

\section{Schulbildung}

$1982-1996$

1996
Katrin Klinge, geb. Lehmann

$$
\text { 31.07.1976 }
$$

Sulingen

deutsch

verheiratet

\section{Universitätsausbildung}

$1996-2002$

2001-2002

2002

2002-2005

\section{Berufstätigkeit}

$2002-2003$

$2003-2005$

2005 -
Schulbildung

Abschluss der Allgemeinen Hochschulreife (Note: 2,2)
Studium der Biologie (Diplom) an der Georg-August-Universität Göttingen externe Diplomarbeit angefertigt im Fachgebiet Agrarökologie des Institutes Agrarwissenschaften der Georg-August-Universität in Göttingen (Betreuer: Prof. T. Tscharntke)

Diplomabschluss (Note: sehr gut)

Promotiumsstudium am Fachgebiet Agrarökologie des Institutes für Agrarwissenschaften der Georg-August-Universität in Göttingen

Wissenschaftliche Mitarbeiterin im Institut für Tierökologie der Philipps-Universität Marburg innerhalb des Projektes „Radiation, Biodiversität und Wirt-Parasit Interaktionen im Rosen-System“ des Schwerpunktes 1127 der Deutschen Forschungsgesellschaft.

Wissenschaftliche Mitarbeiterin im Fachgebiet Agrarökologie der Georg-August-Universität Göttingen innerhalb des Projektes „Radiation, Biodiversität und Wirt-Parasit Interaktionen im RosenSystem“ des Schwerpunktes 1127 der Deutschen Forschungsgesellschaft.

Wissenschaftliche Mitarbeiterin im Institut für Tierökologie der Philipps-Universität Marburg innerhalb des Projektes „Radiation, Biodiversität und Wirt-Parasit Interaktionen im Rosen-System“ des Schwerpunktes 1127 der Deutschen Forschungsgesellschaft. 